\title{
Fire Testing of 55 Gallon Metal Waste Drums For Dry Waste Storage
}

\author{
Prepared for \\ United States \\ Department Of Energy \\ Office of Environment, Safety, and Health \\ Under contract with \\ Westinghouse Hanford Company \\ Richland, WA \\ by \\ H.K. Hasegawa \\ K.J. Staggs \\ S.M. Doughty \\ July, 1993 \\ Fire Research Discipline \\ Special Projects Division \\ Hazards Control Department \\ Lawrence Livermore National Laboratory
}




\section{Fire Testing of 55 Gallon Metal Waste Drums For Dry Waste Storage}

\section{Summary:}

The Fire Research Discipline of the Hazards Control Department of Lawrence Livermore National Laboratory conducted a fire test program funded by the Department Of Energy Office of Environmental, Safety, and Health, and administered by the Westinghouse Hanford Company. The primary goal of this project was to provide information on the fire performance of 55 gallon metal waste drums used for dry waste storage in Department Of Energy facilities.

Six tests were conducted using three different types of drums. In the first test an empty 55 gallon steel drum was heated according to the ASTM E1 19 time temperature curve. In the remaining test various drum configurations were exposed to a 6 foot diameter pool fire. Each drum was filled with 10 kilograms of class " $\mathrm{A}$ " combustibles. During the tests internal pressures and temperatures were monitored.

Failure of the lid seals occurred in all of the drums early in the tests. Hot combustible gases vented from each drum and ignited. In three tests the lids blew off the drums ejecting some of the material from the drums.

Results from these tests showed that heat transfer through the drum side wall is almost unimpeded. Failure of lid seals will allow release of any toxic and/or radioactive materials and smoke contained in the drums. Complete lid failure will expel material from the drums and intensify the fire. These results also indicate that small fires in high bay storage areas will cause drum failures before sprinklers are activated. 


\subsection{Introduction:}

The primary goal of this test program was to conduct a series of fire test to provide information on the fire performance of $\mathbf{5 5}$ gallon metal waste drums used for solid waste disposal at Department Of Energy (DOE) facilities. This program was limited in focus to three different types of $\mathbf{5 5}$ gallon drums, one radiant heat source, and one specific fire size. The initial test was a single empty 55 gallon drum exposed to a standard ASTM E-119 time temperature curve for over 10 minutes. The full scaie tests involved metal drums exposed to a 6 ' diameter flammable liquid fire for a prescribed period of time. The drums contained simulated dry waste materials of primarily class A combustibles. The test results showed that a conventional 55 gallon drum with a 1" bung would blow its lid consistently.

Information on typical drum contents was obtained from Rocky Flats and Westinghouse Hanford.

\subsection{Project Plan:}

The initial test in the series involved a representative empty 55 gallon waste drum. This drum was instrumented and exposed to the ASTM E-119 time temperature curve to evaluate and document its fire performance. The objective of this test was to characterize a drum's fire performance in accordance with a standard large scale test. The environment provided by an ASTM E-119 time temperature curve is that of a flashed over (fully involved) room.

Utilizing 55 gallon metal drums representative of those used throughout the DOE complex for hazardous material storage, 3-4 drums per test were loaded with contents simulating what would be expected in hazardous materials drums. These drums were of varying types (i.e., sealed, vented, polyethylene lined, and over packed). The drums were identified so that a fire performance matrix based on type and contents could be developed. The fire exposure was based on a probable scenario involving a flammable liquid spill. Each drum combination was evaluated from two duplicate full-scale experiments.

Testing was conducted in the LLNL Fire Test Cell. All the drums were instrumented to monitor internal pressures and temperatures. Temperature data was also collected on the furnace and flammable liquid exposure fires. Ventilation through the Test Cell was configured with a low inlet, directed at the base of the fires, and a high outlet. Airflow was in excess of $3000 \mathrm{CFM}$. Exhaust gases were monitored for $\mathrm{O}_{2}, \mathrm{CO}_{2}$, $\mathrm{CO}$ and $\mathrm{HC}$ concentrations. All tests were documented by videotape as well as $35 \mathrm{~mm}$ still photography.

Attachment 1 contains plots of all the data collected from each test. 


\subsection{ASTM E-119 Fire Exposure Test:}

The ASTM E-119 exposure te. . onfiguration with a single empty 55 gallon drum in the test configuration is shown in Figure 1. The apparatus is not a full scale E-1 19 furnace, but rather, a scaled down version capable of reproducing an equivalent time temperature curve. Photos $1 \& 2$ show the overall set up and the placement of the drum in the furnace. The cyclone fencing shown in photo 1 was use to contain the drum and other material in the event of an explosion.

\subsection{WDE119A:}

The drum instrumentation shown in photos $2 \& 3$ includes a pressure probe and thermocouple installed into the drum lid. This array was standard for each drum throughout the test series. Although there is not a formal standard for testing waste drums in an ASTM E-119 furnace, one failure criterion typically used for flammable liquid storage cabinets (NFPA-30, section 4-3) would be the time when the internal temperature exceeded $3250 \mathrm{~F}(1630 \mathrm{C})$. The temperature plot in Figure 2 shows that it took about 140 seconds from test initiation for the internal drum temperature to reach this point. This plot also shows that the internal temperature of the drum closely tracked the furnace temperature. The commonly used auto-ignition temperatures of $500^{\circ} \mathrm{C}$, for the types of materials that would be stored in these drums, was reached at approximately 400 seconds into the test. The pressure plot also shown in figure 2 , shows that the pressure within the drum peaked at $16 \mathrm{psi}$, with the seal failing at around 330 seconds from test initiation. Photos 4 $\& 5$ display the condition of the drum post test. Photo 5 shows the bulge in the lid on the side facing the burners.

\subsection{Flammable Liquid Fires:}

Isopropyl alcohol was used as the fuel for the liquid pool fires, because of its relatively clean burning characteristics, which facilitated visual observations throughout the test duration. The metal drums were placed in the 6 foot diameter metal pan as shown in photo 6 . The pan has a total surface area of $28.25 \mathrm{ft}^{2}$. However, a significant area of the pan was occupied by the drums. This area varied depending on the type and number of drums used in each test. In WDPAN1 the drums occupied approximately $12 \mathrm{ft}^{2}$ of the pans surface area, with the fuel covering an area of $16.25 \mathrm{ft}^{2}$. In WDPAN2\&3 the drums occupied an area of $13 \mathrm{ft}^{2}$, reducing the surface area for the fuel to $15.25 \mathrm{ft}^{2}$. In tests WDPAN4\&5 one less drum was used, allowing a surface area for the fuel of 18.25 $\mathrm{ft}^{2}$. In tests WDPAN1-3 10 gallons of Isopropanal was used to form a layer approximately 0.75 " deep. This was increased to 12 gallons in tests WDPAN4\&5, because of the increased surface area resulting from the elimination of one drum, to maintain a fuel level of 
approximately $0.75^{\prime \prime}$. The alcohol burned for approximately 16 minutes in each test. It is difficult to determine the exact energy levels that the drums were exposed to in these fires. However, we estimate the Heat Release Rate of these fires to be between 0.5-1.0 Megawatts.

Each drum had a total combustible load of approximately $10 \mathrm{~kg}$ ( $22 \mathrm{lbs}$.). This amount filled the drums without packing them down. The specific contents are described in Table 1 and shown in photo 7. This fuel loading consisted of common laboratory items such as polyethylene bags, disposable coveralls, cotton gloves, etc.

Approximately $3500 \mathrm{CFM}$ of air was pulled through the test cell in a low inlet to high outlet configuration. The inlet air was diffused down and across the floor to minimize its effects on the fire. This airflow rate and configuration provided the fire with sufficient quantities of oxygen for combustion and kept the Test Cell clear of smoke, for good visibility.

\subsection{WDPAN1:}

The initial test in this series was a calibration burn that evaluated four identical 17C 55 gallon epoxy coated drums containing lids without bungs. Class A combustibles were packed into the drums as described above and shown in photo 8. Drum location and instrumentation are shown in Figure 3. The overall set up for this test is shown in photo 6.

Figure 4 is a composite plot of the temperatures within the four $\mathrm{dr} \mathrm{ms}$. It shows that the ignition temperature for the drum contents was reached at about 400 second for three of the four drums. The temperature in the fourth drum appeared to follow the alcohol fire temperature almost exactly. The drum pressures are summarized in Figure 5. All drums vented around 300 seconds as indicated by the sudden drop in pressure. The test fire lasted for approximately 10 minutes without violent failure of any of the drums. Photo 9 shows that all the drum lids buckled or bulged on the side facing the center of the pan. Photo's 10-13 show that much of the drum contents were burned or charred. The charred remains of the drum lid seal are shown in photo 14 .

\subsection{WDPAN2 \&3:}

Two identical tests were conducted for this test series, WDPAN2 and WDPAN3. A total of 5 drums were tested in each test. The positioning of the drums and instrumentation are shown in Figure 6 and photo 15 . Drums $1,2 \& 5$ were standard 55 gal $17 \mathrm{C}$ waste drums. Drum 3 was an over pack or salvage drum that 
encased drum 5 and its contents. These drums are shown in photo 16. Drum 4 was a Transuranium (TRU) drum, and was loaded as describe above and shown in photo 17. Photo 18 shows drum 4 with the top of the liner in place. An additional thermocouple and pressure probe were placed in the space between the inner drum (drum \#5) and the salvage drum (drum \# 3).

\subsubsection{WDPAN2 Events:}

Approximately 194 seconds, after ignition of the alcohol, combustible gases venting through lid seals of drums 1 and 4 ignited. At 200 seconds the lid to drum 1 buckled. A significant event occurred at 277 seconds when drum number 1's lid blew off emitting a fire ball and explosive sound. Burning material was ejected from the drum and the fire intensified. The alcohol fire went out at approximately 960 seconds, however, the debris ejected from drum number 1 continued to burn. A flame extending out from the 1" bung hole in drum number 3's lid became visible after the alcohol fire died down. Flames from the lid seal area of each drum and from the 1" bung hole in the salvage drum, went out shortly after the alcohol and ejected debris stopped burning. The materials within drum number 1 continued to burn until it was extinguished with a hand held $\mathrm{CO}_{2}$ fire extinguisher.

\subsubsection{WDPAN2 Results:}

The plots shown in figures $7 \& 8$ are composites of the internal drum pressures and temperatures. The plots in figure 7 show that number 1 drum vented at approximately 205 seconds into the test, with a total loss of pressure occurring at approximately 275 seconds. The plots in figure 8, show that the maximum internal drum temperature at this point was $480^{\circ} \mathrm{C}$. Data from these plots show that drum 2 vented at 180 seconds with an internal temperature of just over $400^{\circ} \mathrm{C}$. This data also shows, that the number 3 drum started to vent at 180 seconds, with a total pressure loss occurring at 280 seconds at an internal temperature of $280^{\circ} \mathrm{C}$. These plots also show, that the pressure in the number 4 drum oscillated between near zero to one psi during the test. The pressure was constantly being relieved in this drum through the nuclear grade filter that is incorporated into the lid. The temperature data shows that the maximum internal temperature achieved, in this drum, was $700^{\circ} \mathrm{C}$. The final plot lines show that the number 5 drum (Inner drum) vented at 550 seconds, at just under $11 \mathrm{psi}$, with an internal temperature of approximately $350^{\circ} \mathrm{C}$. Additional analysis of this data show, that the maximum internal temperature for drums 1,4 and 5 was approximately $700^{\circ} \mathrm{C}$, and drums 3 and 5 were approximately $400^{\circ} \mathrm{C}$ and $480^{\circ} \mathrm{C}$ respectively. 
The condition of the drums after the test is shown in photo 19. Shown in photo 20 is the lid that blew off drum 1, which came to rest upside down on top of this drum. Photo 21 shows the buckling that occurred in the lid on drum 2. Photo 22 shows the opened bung hole, in the salvage drum, that had the flame extending from it as describe earlier in this report.

\subsubsection{WDPAN3 Events:}

Approximately 170 second after igniting the alcohol, number 2 drum vented along its lid seal area. At 178 seconds the number 1 drum lid buckled. At 259 seconds the number 1 dram started to vent along the lid seal area. At 283 seconds the TRU drum started to vent along the lid seal area. The number 1 drum blew its lid off emitting a fire ball and explosive sound. The alcohol fire went out at approximately 960 seconds, however, debris ejected from the number 1 drum continued to burn. At 1333 seconds the flaming along the lid seal area of the number 2 drum went out. The flame coming from the salvage drum bung hole went out at approximately 1753 seconds. At 2103 seconds the flame from the lid ring area of the TRU drum went out. As in test WDPAN2 the debris ejected from the exploding drum was extinguish with a $\mathrm{CO}_{2}$ fire extinguisher.

\subsubsection{WDPAN3 Results:}

The plots shown in figures $9 \& 10$ are composites of the internal drum pressures and temperatures. The plots in figure 9 show that number 1 drum initially vented at approximately 130 seconds into the test. The pressure then increased to $12.5 \mathrm{psi}$ and the drum started to vent again at 185 seconds, with a total loss of pressure occurring at approximately 250 seconds. The plots in figure 10 show that the maximum internal temperature of drum 1 during this period was approximately $450^{\circ} \mathrm{C}$. The data also shows that drum 2 vented at 175 seconds with an internal temperature of just over $300^{\circ} \mathrm{C}$. The salvage drum vented at 150 seconds at an internal temperature of approximately $150^{\circ} \mathrm{C}$. The plots for the TRU drum show the pressure slowly increasing to approximately 2.75 psi then dropping down to below 2 psi at 260 seconds. The pressure continued to decline in this drum over the duration of the test and reached near 0 by the time the alcohol fire went out. The drum 5 (inner drum) vented at 390 seconds at an internal temperature of just over $220^{\circ} \mathrm{C}$. Additional analysis of this data show that the maximum internal temperatures for the drums were between 400 and $600^{\circ} \mathrm{C}$.

The condition of the drums after the test is shown in photo 23. Photo 24 shows the lid that blew off drum number 1. The remains of the liner and materials inside the TRU drum (drum 4) are shown in photo 25. 


\subsection{WDPAN4\&5:}

Two identical tests were conducted for this test series, WDPAN4 and WDPAN5. The setup for these tests is shown in figure 11 and photo 26 . This set up is similar to WDPAN2\& 3 except the TRU drum was eliminated, and each drum was lined with a 10 mil polyethylene (PE bag) liner as shown in photo 27. The PE liner was a standard drum liner used for 55 gallon metal waste drums, and was folded over at the top as shown in photo 28. The numbering sequence for the salvage and inner drum was changed from $3 / 5$ to $3 / 4$, number 3 being the salvage drum and number 4 being the inner drum. The drums were positioned in a triangular configuration. Each drum was packed as describe earlier in this report.

\subsubsection{WDPAN4 Events:}

Approximately 226 seconds into the test number 1 drum lid buckled. It was not possible to determine if this drum was venting at this point because it was masked by the flames from the alcohol fire. At 953 seconds flames could be seen coming from the number 1 drum lid seal area. At 1013 seconds the fire from the alcohol went out. At 1553 seconds the fire coming from number 1 drum lid seal area went out. Although both number 1 and 2 drum lids buckled, neither drum lid blew during this test.

\subsubsection{WDPAN4 Results:}

The plots shown in figures 12 and 13 are composite plots of the internal drum pressures and temperatures. These graphs show that drum 1 initially vented at 220 seconds with continuous venting occurring at approximately 240 seconds. Drum 2 initially vented at 150 seconds with continuous venting occurring at 225 seconds. The maximum internal drum pressures reached before continuous venting were $13.3 \mathrm{psi}$ and 14.2 psi respectively. The internal temperatures for the number $1 \& 2$ drums at this time were approximately $100^{\circ} \mathrm{C}$ and $300^{\circ} \mathrm{C}$ respectively. The salvage drum vented at 150 seconds with an internal temperature of approximately $190^{\circ} \mathrm{C}$ and a maximum pressure of $7 \mathrm{psi}$. The inner drum vented at 560 seconds after reaching a maximum pressure of $15.5 \mathrm{psi}$ with an internal temperature of just over $500^{\circ} \mathrm{C}$. Photo 21 shows the condition of the drum after the test.

The condition of the drums after the test is shown in photo 29. 


\subsubsection{WDPAN5 Events:}

Approximately 203 seconds after the start of the test the number 2 drum blew its lid expelling some of its internal contents into the pan. Since this drum was masked by the number $1 \mathrm{drum}$, it was not possible to determine if it was venting or burning along its lid seal area. At 232 seconds the number 1 drum started to vent along its lid ring area. Buckling was noticed at 245 seconds and the escaping gas coming from the lid ring area ignited. At 785 seconds the fire from the alcohol diminished but the flames from the venting drum and debris were still burning. The flame coming from the salvage drum bung hole slowly went out at approximately 1896 seconds. The fire from the remaining burning debris in the number 2 drum was finally put out using a $\mathrm{CO}_{2}$ extinguisher.

\subsubsection{WDPAN5 Results:}

The plots shown in figures 14 and 15 are a composite of the internal drum temperatures and pressures. These graphs show that number 1 drum vented at approximately 240 seconds into the test. The temperature probe failed when the number 2 drum blew. However, the maximum temperature reached, just before the drum blew, was over $300^{\circ} \mathrm{C}$ The pressure data shows that the number 2 drum vented at 200 seconds. Its internal temperature, just before it blew, reached just over $400^{\circ} \mathrm{C}$. The salvage drum vented at 130 seconds at an internal temperature of approximately $550^{\circ} \mathrm{C}$. The inner drum (number 5 drum) vented at 475 seconds at an internal temperature of just over $400^{\circ} \mathrm{C}$.

The condition of the drums after the test is shown in photo 30. The lid from number 2 drum was found next to the pan as shown in photo 31 . Photos 32 show the number 2 drum lid after it was placed back into position on top of the drum.

\subsection{Flammable Liquid Fires Results:}

All drums for which the lid completely failed were standard 55 gallon $17 \mathrm{C}$ drums with lids containing a 1" bung hole. A summary of the pressures, temperatures and time to failure is shown in Table 2. None of the drums with solid lids blew. Lids on all the 17C type drums buckled on the sides facing inward to the middle of the pan. This buckling allowed the hot combustible gasses inside to vent and ignite. The data also show that internal pressures in the drums that experienced complete lid failure were between 8-13 psi. Pressure buildup in the Salvage drums, from gases venting from the inner drums, was relieved early in the tests when the 1" plastic bungs partly melted and blew out. Photos 33-35, selected from test WDPAN5, 
show that the lids on the inner drums also buckled and vented, sometimes swelling against the salvage drums causing the lids and bottoms to bulge. The pressure buildup in the TRU drums was relieved through the filter, which prevented the lid from buckling. However, the lid seals failed on both TRU drums tested, allowing combustible gases to escape and ignite.

The thermocouples inside the drums (located at approximately $1 / 3$ the diameter from the side wall and 1' down from the top) provided a measure of drum internal air temperature. Actual drum side wall temperatures would have been significantly higher. Material near or against the side walls would have experienced temperatures above $500^{\circ} \mathrm{C}$. This temperature is above the auto ignition temperature for these types of materials. However, because of the limited oxygen available within each drum, only a smoldering type of fire could exist. Pyrolyzates (combustible gases), occurring from the pyrolytic decomposition of material due to external heating or smoldering combustion within the drums, escaped and ignited when the lid seals failed.

The mass loss, summarized for these tests in Table 3, indicate that a significant amount of material was release from each drum. Obviously, the greatest weight loss occurred in drums that blew off their lids. The average weight loss of material for a 17C type drum, in which the lid did not blow off, was approximately 1 kilogram. For comparison purposes, this equates to a complete loss of 2 Polyethylene bags, 2 coveralls, 2 dust masks, 2 pairs of shoe covers, 2 pairs of gloves, 2 caps, and a half box of paper wipes.

The average weight loss for the TRU drum in tests WDPAN 2 and 3 was approximately 1.5 kilograms. Although some of the gases produced in this drum during the test were released through the filter, a significant amount of the drum contents were pushed out past the lid seal. It was not possible from these tests to determine how much material vented out past the lid seal. However, the data shows that during these tests, pressures in these TRU drums fluctuated and sometimes dropped sharply. This was probably a result of pressure being relieved through failures occurring in the lid seals during these tests.

The average weight loss for the inner drums was approximately 0.2 kilograms. The weight loss of the material in the inner drums was minimized because they were insulated form the fire by the salvage drums. Flaming was not observed along the lid seal area of the salvaged drum during these tests. It appears that early on in each test the plastic plugs in the salvage lids melted, allowing gases released from the inner drum to escape through this opened bung hole. 


\subsection{Discussion:}

The configuration of the drums in the containment pan used in these tests resulted in a relatively small liquid pool fire. Since the drums were placed on the bottom of the pan, the surface area for the pool fire was significantly reduced. The area in the pan where significant burning occurred was at the center of the pan between the drums. This area was approximately 18" in diameter. A thin flame developed along the drum walls facing outward, because of the narrow gap formed between the drums and the edge of the pan. Even though the fire exposure was relatively small, tests results showed that loss of containment occurred in all of the $\mathbf{5 5}$ gallon metal drums.

External heating from the test fire caused the waste within the drums to melt and/or decompose. As a result, pressure developed within the drums. Drums containing filters developed significantly less pressure, since it was being relieved through the filter. Heating from the fire quickly caused the lid seals to decompose and the lids to warp, releasing combustible gases from the drums. Upon contact with the external fire these combustible gases ignited, resulting in a small deflagration.

Complete lid failure was experienced in drums containing lids with one inch bungs. Essentially, heat and pressure buckled these lids causing them to pull out from under the locking ring. This could be coincidental or perhaps a result of mechanical weaknesses induce into the lid from the one inch bung hole. The resulting fire ball or explosion that occurs when the lid fails is due to the ignition of combustible gases released from the drum.

As previously stated in this report the fire strength used for these tests was relatively small. In high-bay areas a fire of this size might not activate the sprinklers soon enough to prevent the drum lids or seals from failing. This would result in the release of toxic and/or radioactive contaminate smoke and gases into the environment. In addition, complete lid failure from a drum supporting other drums would cause them to topple, exacerbating the problem.

Larger fires could resuit in complete failure of other types of lids, or cause the drums to rupture. Even drums containing lids with vents might experience complete failure. The resulting deflagration from these types of failure could be significantly greater than the one experienced in this test series. 


\subsection{Conclusions:}

- Heat transfer through the drum side wall is almost unimpeded.

- Only 17C Drums (4 tested) with lids that have 1" bung holes completely failed. All standard drum (17C) lids buckled on the side facing the hottest point of the fire.

- Average time from start of fire until the lids ( 3 lids) blew was less than 5 minutes. In high bay storage areas lid failure could occur before sprinkler activation.

- Lid seal failure would allow toxic and/or radioactive materials/smoke/gases to be released into the environment. Complete lid failure would eject burning material and debris, intensify the fire and contaminate the area.

- Multiple stacked drums could be toppled when lid(s) blow.

- This fire exposure is relativity small, a more severe exposure might cause complete failure of the lids on other types of drums.

- This was a limited test series that tested the response of three different types of drum to one specific fire. The response of these drums to larger fires might result in other or more significant types failures. 
Description and Weights of Materials Loaded into Drum

Each drum, except the salvage drum, was loaded with the following items (total fuel load 10kg):

\begin{tabular}{|l|l|l|l|}
\hline $\begin{array}{l}\text { Number of } \\
\text { Items }\end{array}$ & \multicolumn{1}{|c|}{ Description of Item } & $\begin{array}{c}\text { Total Weight } \\
\text { grams }\end{array}$ & $\begin{array}{l}\text { Weight/tem } \\
\text { grams }\end{array}$ \\
\hline 25 each & 5mil polyethylene bags & $\sim 3500$ & $\sim 140$ \\
\hline 25 each & Tyvek* coveralls, white with zipper closure P/N 35-1412L, White Knight Health Care & $\sim 3000$ & $\sim 120$ \\
\hline 25 each & 3M Dust and Mist respirators P/N 8710, 3M Occupational Health \& Environmental Safety Div. & $\sim 190$ & $\sim 7.6$ \\
\hline 50 each & Dura-Fit Shoe Covers, Shoe Converters, Baxter cat. No. 4850 & $\sim 425$ & $\sim 8.5$ \\
\hline 50 each & 9 oz. Cotton Gloves, Reversible Jersey, Century Glove No. FF8506M-L & $\sim 1090$ & $\sim 21.8$ \\
\hline 25 each & Cap, Bouffant, Disposable, Non-Woven Material, all purpose ware, ABANDA style 1000 & $\sim 90$ & $\sim 3.6$ \\
\hline$\sim 2$ boxes ${ }^{* *}$ & Soft_tech wipes 90 wipes per box 15"x17" 2 ply P/N 8357 & $\sim 1500+$ & $\sim 8.33$ \\
\hline * Dupont Registered Trademark &
\end{tabular}

** The number of wipes for each tests was varied to obtain the desired weight of $10 \mathrm{~kg}$

Table 1

Summary of Drum Pressures and Temperatures

\begin{tabular}{|c|c|c|c|c|c|c|c|c|c|c|c|c|c|c|c|c|c|c|c|c|c|c|}
\hline Test $\rightarrow$ & \multicolumn{4}{|c|}{ WDPAN1 } & \multicolumn{5}{|c|}{ WDPAN2 } & \multicolumn{5}{|c|}{ WDPAN3 } & \multicolumn{4}{|c|}{ WDPAN4 } & \multicolumn{4}{|c|}{ WDPAN5 } \\
\hline Drum Number & \#1 & \#2 & \#3 & \#4 & \#1 & \#2 & \#3 & \#4 & \#5 & \#1 & \#2 & \#3 & \#4 & \#5 & \#1 & \#2 & \#3 & \#4 & \#1 & \#2 & \#3 & \#4 \\
\hline $\begin{array}{l}\text { Max Pressure } \\
\text { (psi) }\end{array}$ & 8.0 & 10.5 & 12.8 & 12.4 & 8.6 & 11.4 & 7.0 & 1.0 & $\overline{11.8}$ & 12.5 & 12.5 & 5.0 & 2.5 & 5.0 & 14.1 & 12.7 & 6.9 & 14.8 & 11.8 & 13.2 & 14.0 & 13.2 \\
\hline $\begin{array}{l}\text { Max Temperature } \\
\left({ }^{\circ} \mathrm{C}\right)\end{array}$ & 570 & 570 & 520 & 820 & 475 & 740 & 400 & 730 & 710 & 440 & 600 & 400 & 590 & 460 & 445 & 725 & 390 & 425 & $360 t$ & $450+$ & 700 & 500 \\
\hline $\begin{array}{l}\text { Time to Failure*** } \\
(\mathrm{sec})\end{array}$ & 200 & 200 & 200 & 200 & $\begin{array}{l}195 \\
270^{*}\end{array}$ & 180 & 135 & 345 & 540 & $180^{*}$ & 180 & 150 & 270 & 380 & 225 & 210 & 135 & 540 & 240 & \begin{tabular}{|l|}
600 \\
$200 *$
\end{tabular} & 140 & 470 \\
\hline $\begin{array}{l}\text { Pressure at } \\
\text { Failure** (psi) }\end{array}$ & 8 & 10.5 & 12.8 & 12.4 & 8.2 & 11.4 & 7.0 & 0.8 & 11.8 & $12.5^{*}$ & 12.5 & 5.0 & 2.6 & 5.0 & 14.1 & 12.7 & 6.9 & 14.8 & 11.8 & $\begin{array}{l}3.0 \\
13.2 *\end{array}$ & 14.0 & 13.2 \\
\hline $\begin{array}{l}\text { Temperature at } \\
\text { Failure** }\left({ }^{\circ} \mathrm{C}\right)\end{array}$ & 350 & 390 & 270 & 710 & $450^{*}$ & 450 & 250 & 60 & 450 & $400^{*}$ & 300 & 120 & 30 & 220 & 90 & 220 & 180 & 380 & $360+$ & $\begin{array}{l}40 \\
450+\end{array}$ & 570 & 410 \\
\hline
\end{tabular}

* Failure is determined to be when the first sigaificant pressure drop in the drum occurs.

* alue when the lid was blown completely off. the drum.

$+\quad$ hermocouple failed, estimated temperature is higher than value listed.

Table 2 
Drum Loading and Weight Loss

\begin{tabular}{|c|c|c|c|c|c|c|c|c|c|c|c|c|c|c|c|c|c|c|c|c|c|c|}
\hline Test $\rightarrow$ & \multicolumn{4}{|c|}{ WDPAN1 } & \multicolumn{5}{|c|}{ WDPAN2 } & \multicolumn{5}{|c|}{ WDPAN3 } & \multicolumn{4}{|c|}{ WDPAN4 } & \multicolumn{4}{|c|}{ WDPAN5 } \\
\hline Drum Number & \#1 & \#2 & \#3 & $\# 4$ & \#1 & \#2 & $\# 3^{*}$ & \#4 & $\# 5^{* *}$ & \#1 & \#2 & $\# 3^{*}$ & $\# 4$ & $\# 5^{* *}$ & $\# 1$ & \#2 & $\# 3^{*}$ & $\# 4^{* *}$ & \#1 & \#2 & $\# 3^{*}$ & $\# 4^{* *}$ \\
\hline $\begin{array}{l}\text { Drum Weight } \\
\text { (kg) }\end{array}$ & 27.0 & 26.9 & 27.0 & 27.0 & 26.9 & 27.0 & 35.0 & 38.6 & 27.0 & 27.0 & 27.0 & 34.9 & 38.7 & 26.9 & 27.0 & 27.0 & 35.0 & 27.0 & 27.0 & 27.1 & 34.8 & 26.9 \\
\hline $\begin{array}{l}\text { Load Weight } \\
\text { (kg) }\end{array}$ & 10.0 & 10.0 & 10.0 & 10.1 & 10.0 & 10.1 & N/A & 10.5 & 10.4 & 10.0 & 10.1 & NA & 10.1 & 10.1 & 10.0 & 10.0 & NA & 10.0 & 10.0 & 10.0 & NA & 10.0 \\
\hline $\begin{array}{l}\text { Total } \\
(\mathrm{kg})\end{array}$ & 37.0 & 36.9 & 37.0 & 37.0 & 36.9 & 37.1 & NA & 49.0 & 37.5 & 37.0 & 37.1 & NA & 48.8 & 37.0 & 37.0 & 37.0 & NA & 37.0 & 37.0 & 37.1 & NA & 36.9 \\
\hline $\begin{array}{l}\text { Post Test } \\
\text { Weight (kg) }\end{array}$ & 35.8 & 36.0 & 36.3 & 36.2 & 28.1 & 36.0 & N/A & 47.4 & 37.1 & 27.9 & 35.9 & NA & 47.3 & 36.7 & 35.9 & 36.4 & N/A & 36.9 & 36.2 & 29.0 & N/A & 36.7 \\
\hline $\begin{array}{l}\text { Weight Loss } \\
(\mathrm{kg})\end{array}$ & 1.2 & 0.9 & 0.7 & 0.8 & 8.8 & 1.1 & NA & 1.6 & 0.4 & 9.1 & 1.2 & NA & 1.5 & 0.3 & 1.1 & 0.6 & N/A & 0.1 & 0.8 & 8.1 & NA & 0.2 \\
\hline $\begin{array}{l}\text { Total Weight } \\
\text { Loss (kg) }\end{array}$ & \multicolumn{4}{|c|}{3.6} & \multicolumn{5}{|c|}{11.9} & \multicolumn{5}{|c|}{12.1} & \multicolumn{4}{|c|}{1.8} & \multicolumn{4}{|c|}{9.1} \\
\hline
\end{tabular}

* The Salvage drum contain Drum \#5 and it's contents.

** This drum was weight separate from the Salvage drum.

Table 3 


\section{E119 Test Configuration}

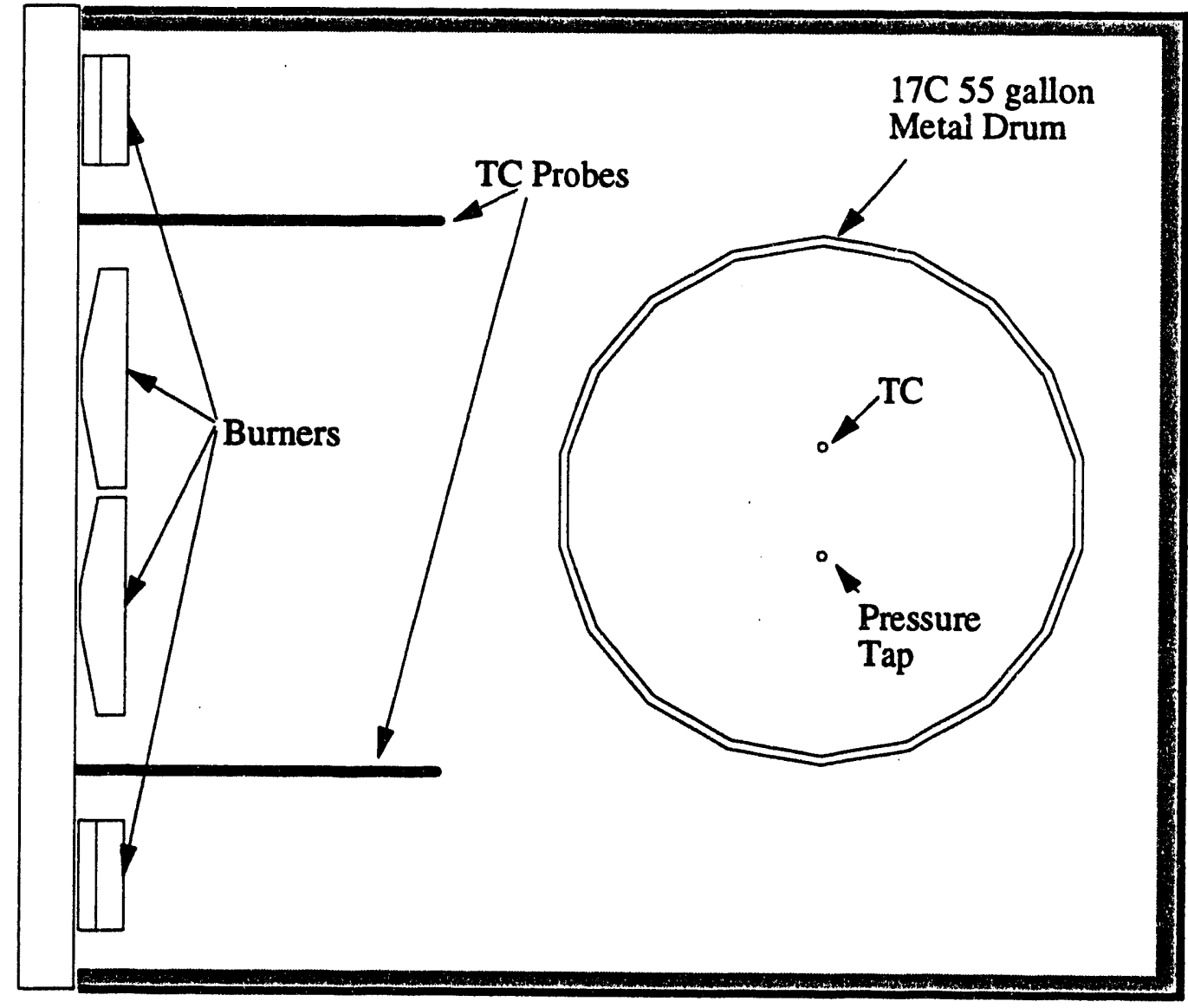

PLAN VIEW

Insulated Enclosure (all sides, top and bottom)

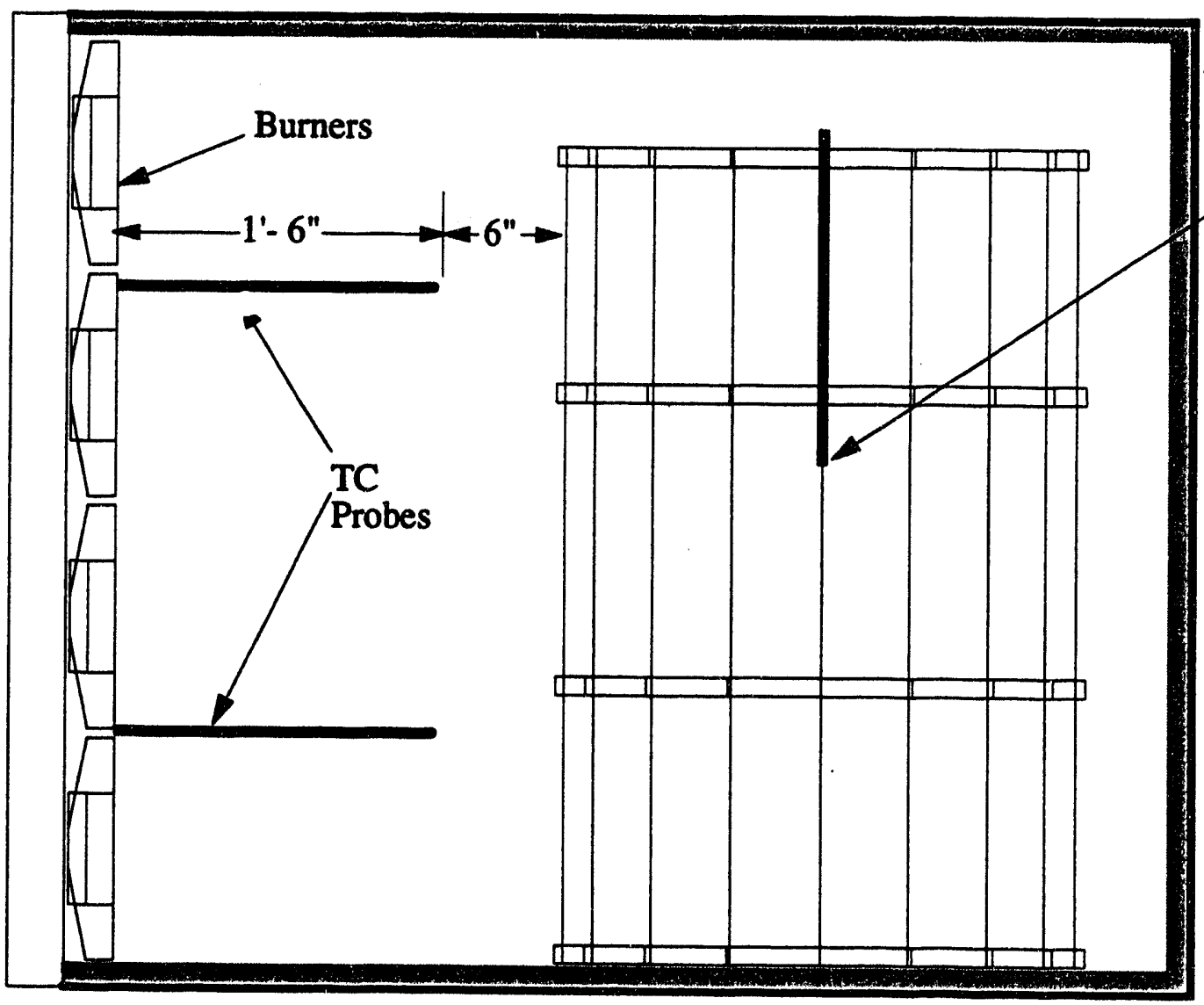

Pressure Probe

and TC 12" down from top of Drum. 
Date: 19 May 19

FILENAME CHANNEL LOCATION

WDE 119 A

$\times$ WDE119R

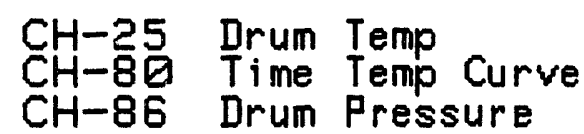

Time: $09: 42: 21$ UNIT OF MEASURE SCRLE Degrees Celsius 1000 Degrees Celsius 1000

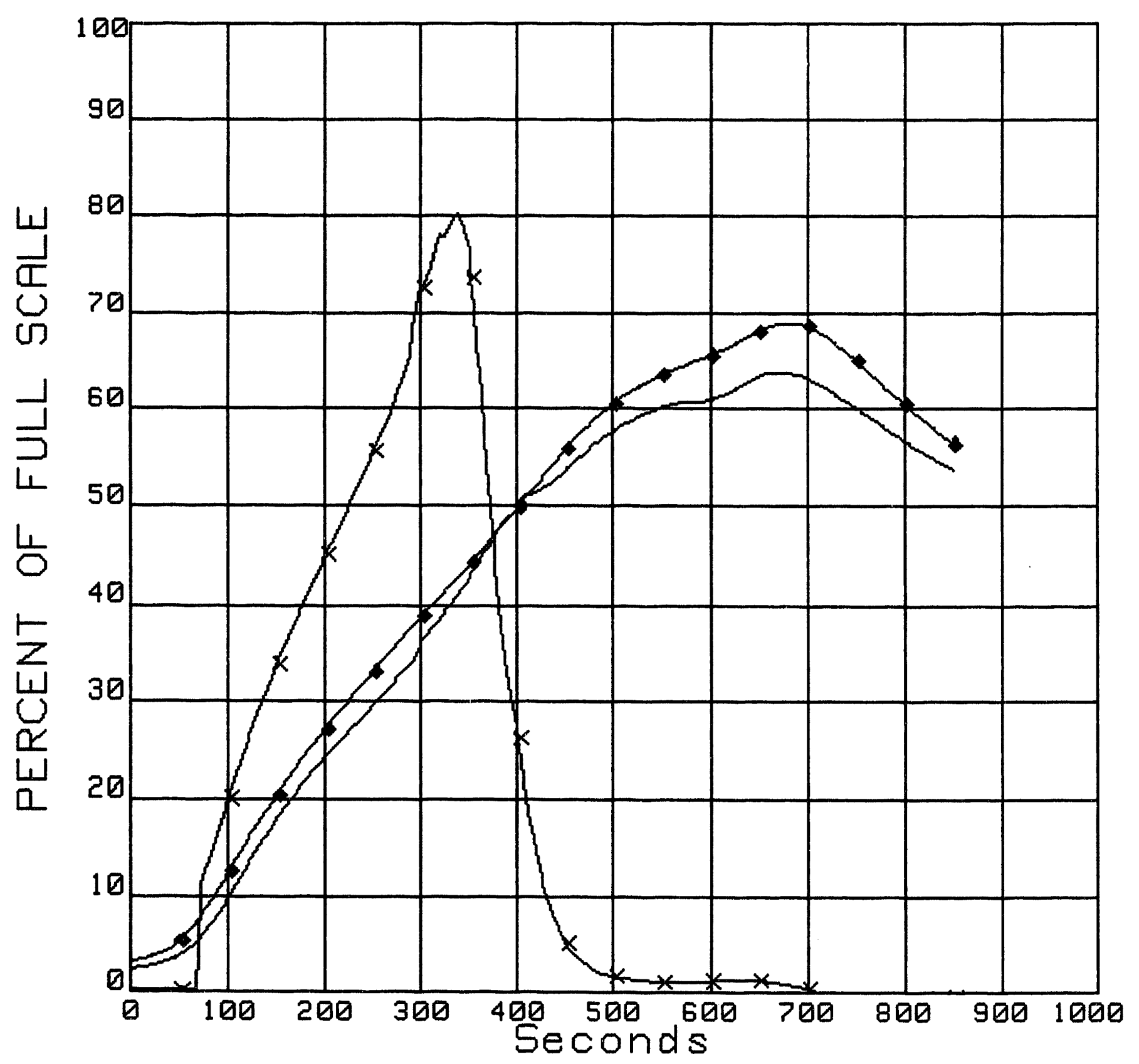

Figure 2 

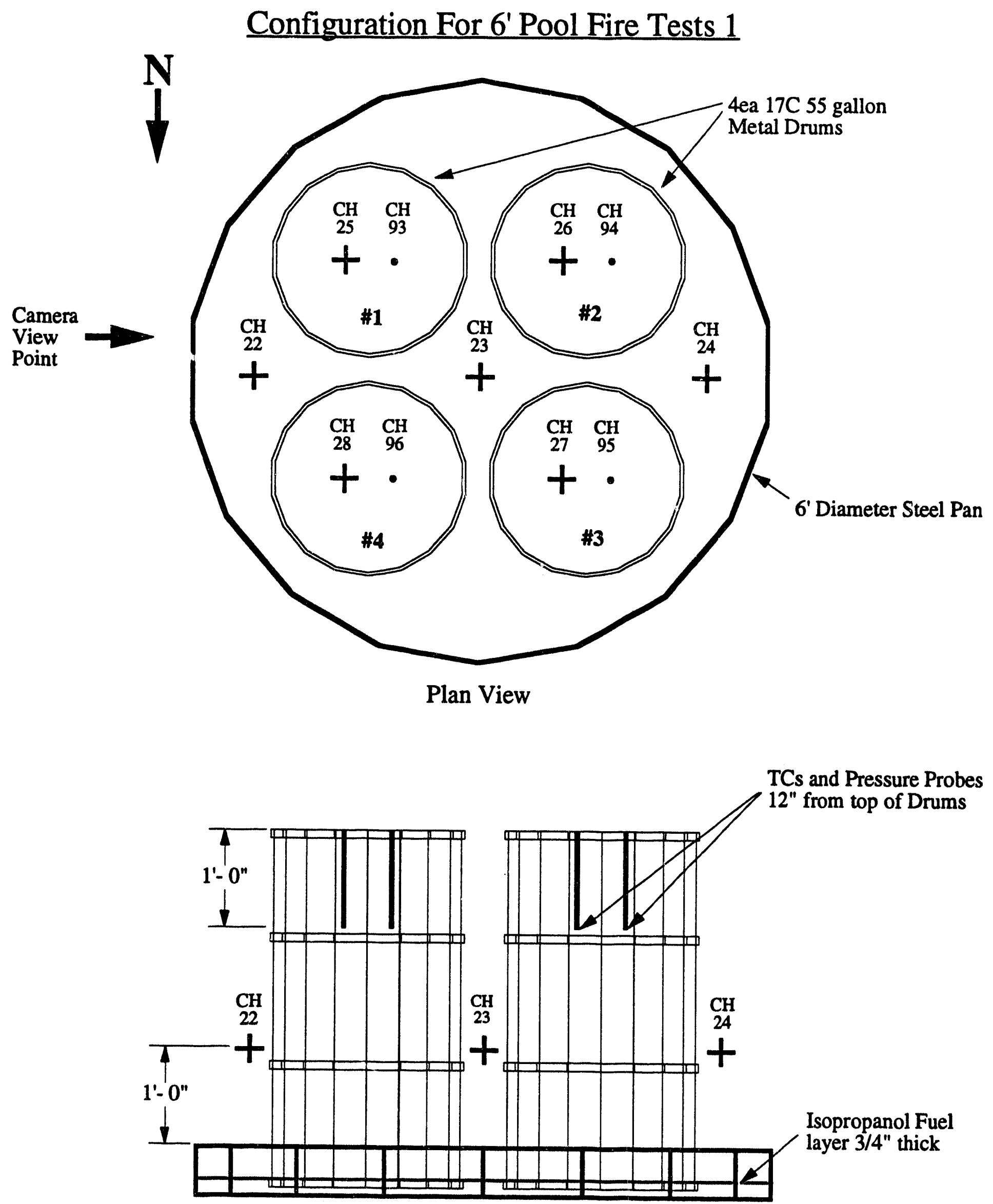
Date: 7 Jun 19

FILENAME CHANNEL LOCATION

WDPAN 1

- WDPAN I

$\times$ WDPAN 1

- WDPANI

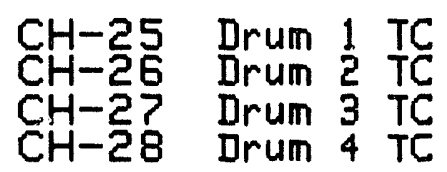

Time: $10: 02: 43$ UNIT OF MEASURE SCRLE

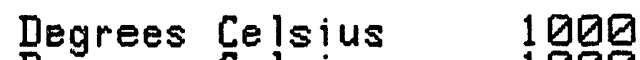
Degrees Celsius 1000 Degrees Celsius 1000 Degrees Celsius 1000

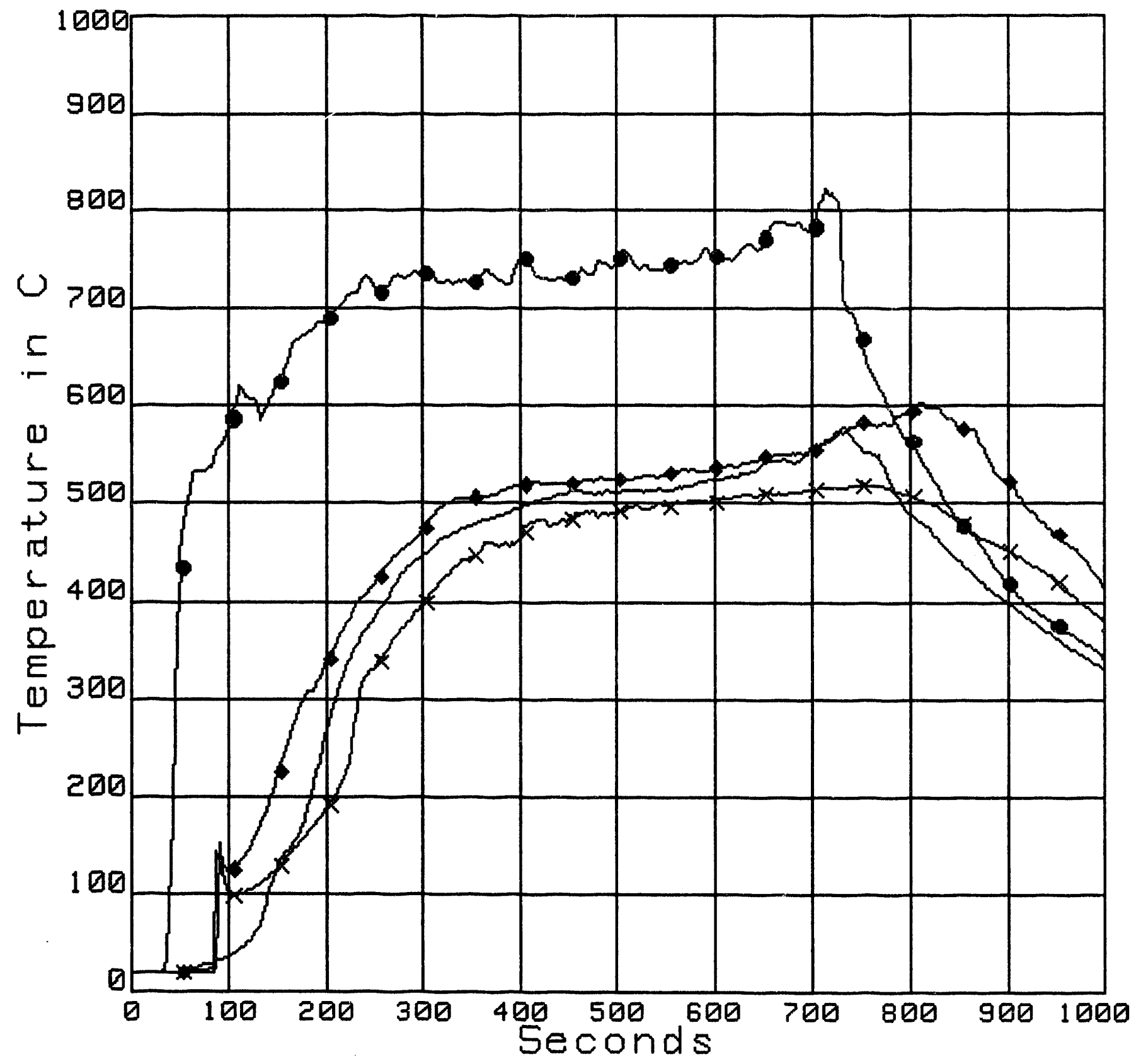

Figure 4 
Date: 7 Jun 19

FILENAME CHANNEL LOCATION WDPAN 1

- WDPAN 1

$\times$ WDPAN 1

- WDPRN 1
CH-93 Drum 1 TD

$\mathrm{CH}-94$ Drum 2 To

CH-95 Drum 3 TD

$\mathrm{CH}-96$ Drum 4 TD
Time: 10:02:43 UNIT OF MEASURE SCRLE P5I

PSI

P5I

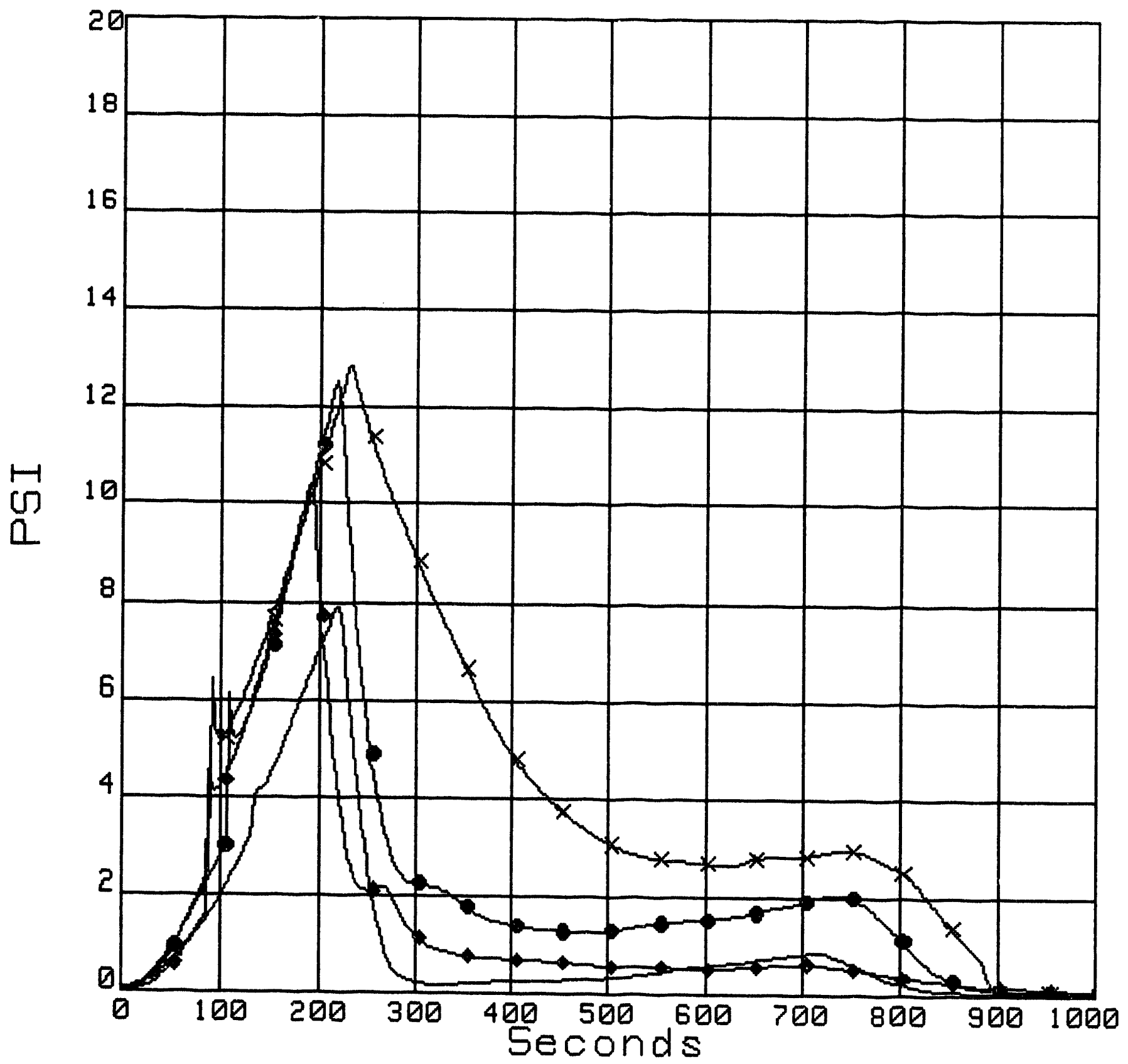

Figure 5 

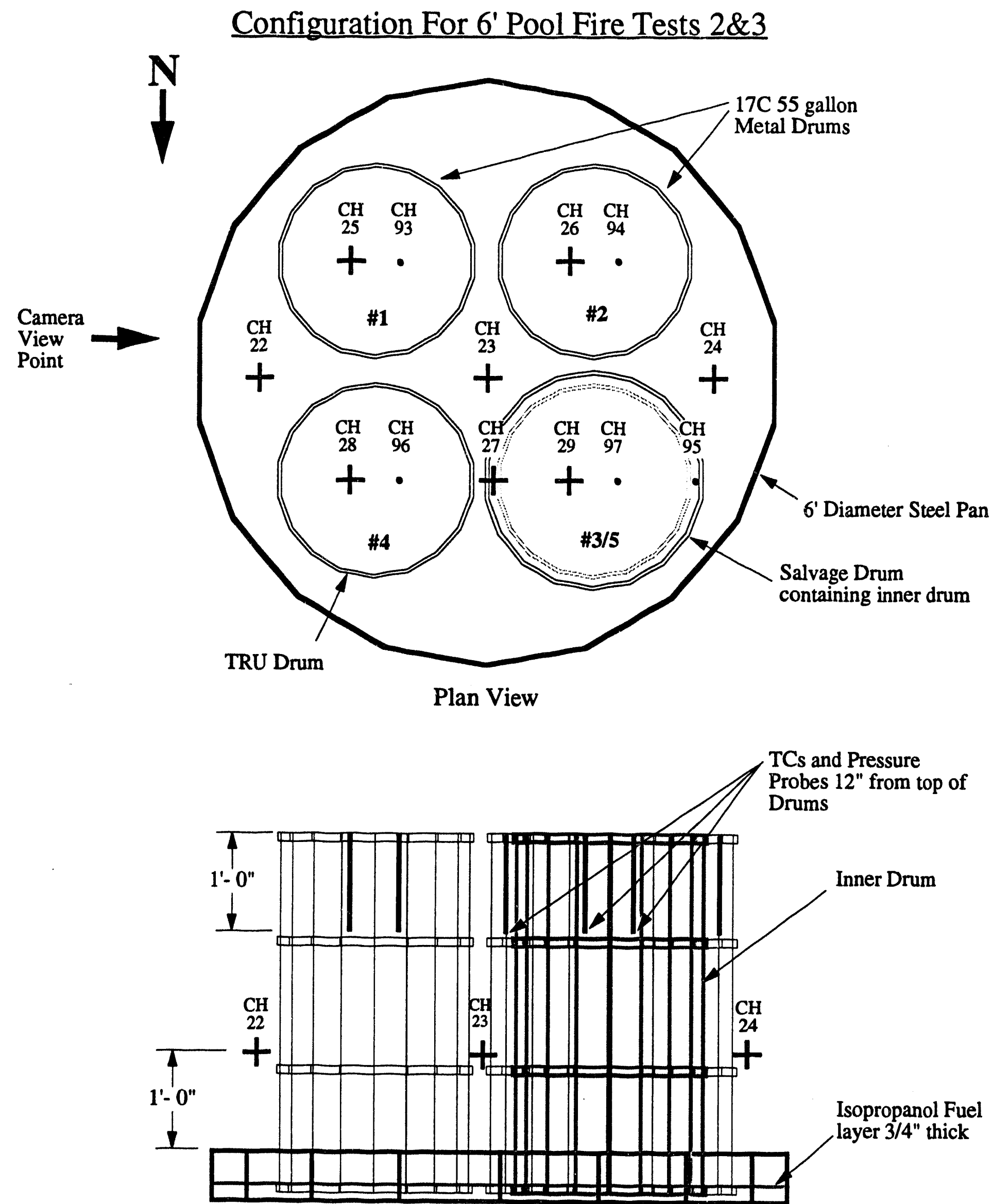

t TC - Thermocouples

Side View

Figure 6 
Date: 14 Jun 19

FILENAME CHANNEL LOCATION

WDPAN2

- WDPAN2

$\times$ WDPAN2

- WDPAN2

-WDPAN2
$\mathrm{CH}-93$ Drum 1 TD

$\mathrm{CH}-95$ Salvage Drum TD

$\mathrm{CH}-96$ TRU Drum TD

$\mathrm{CH}-97$ Inner Drum $\mathrm{TO}$
Time: $11: 48: 44$ UNIT OF MEASURE SCALE

PSI

PSI

P5I

PSI

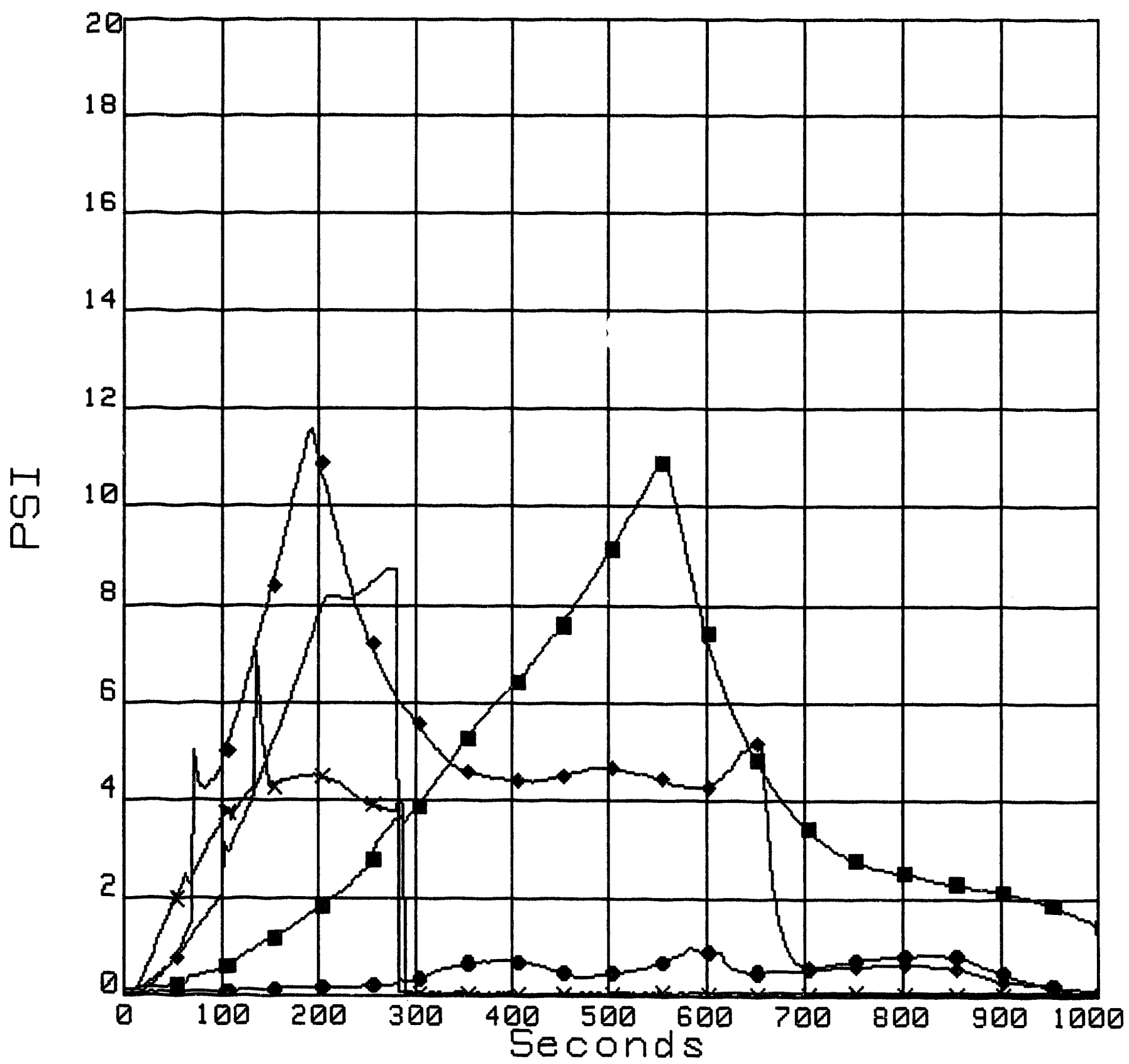

Figure 7 
Date: 14 Jun 19

FILENAME CHANNEL LOCATION

WDPAN2

- WDPAN2

$\times$ WDPAN2

- WDPAN2

- WDPAN2
CH-25 Drum 1 TC

CH-2? Salvage Drum TC

$\mathrm{CH}-28$ TRU Drum TC

$\mathrm{CH}-29$ Inner Drum $\mathrm{TC}$
Time: $11: 48: 44$

UNIT OF MEASURE SCALE

Degrees Celsius 1000

Degrees Celsius 1000

Degrees Celsius 1000

Degrees Celsius 1000

Degrees Celsius 1000

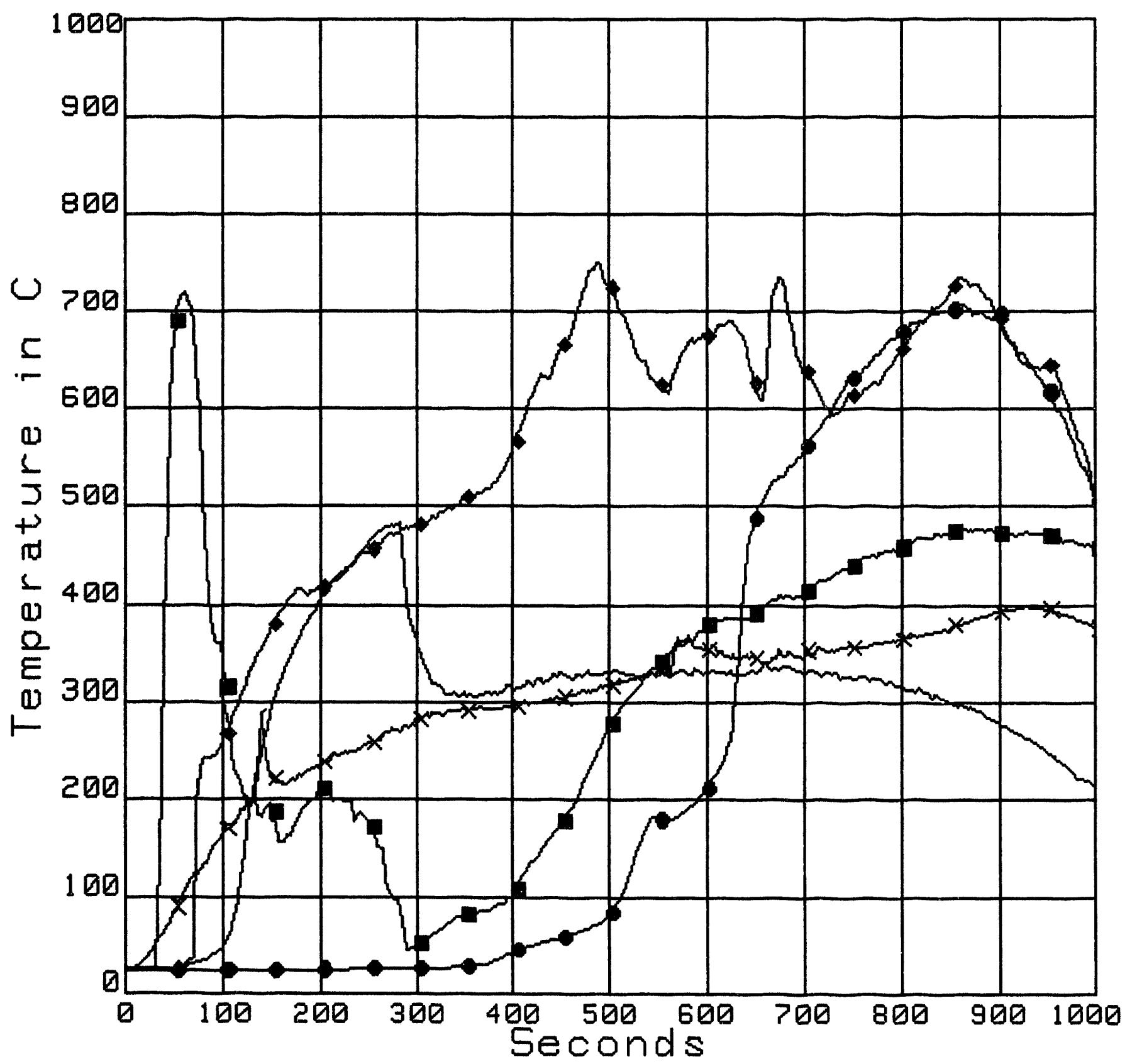

Figure 8 
Date: 17 Jun 19

FILENAME CHANNEL LOCATION

WDPAN3

- WDPAN3

$\times$ WDPAN3

- WDPAN3

- WDPAN3
CH-93 Drum 1 TD

$\mathrm{CH}-95$ Salvage Drum TD

$\mathrm{CH}-96$ TRU Drum TD

$\mathrm{CH}-97$ Inner Drum TO
Time: 14:09:55 UNIT OF MEASURE SCALE

PSI

PSI

P5I

P5I

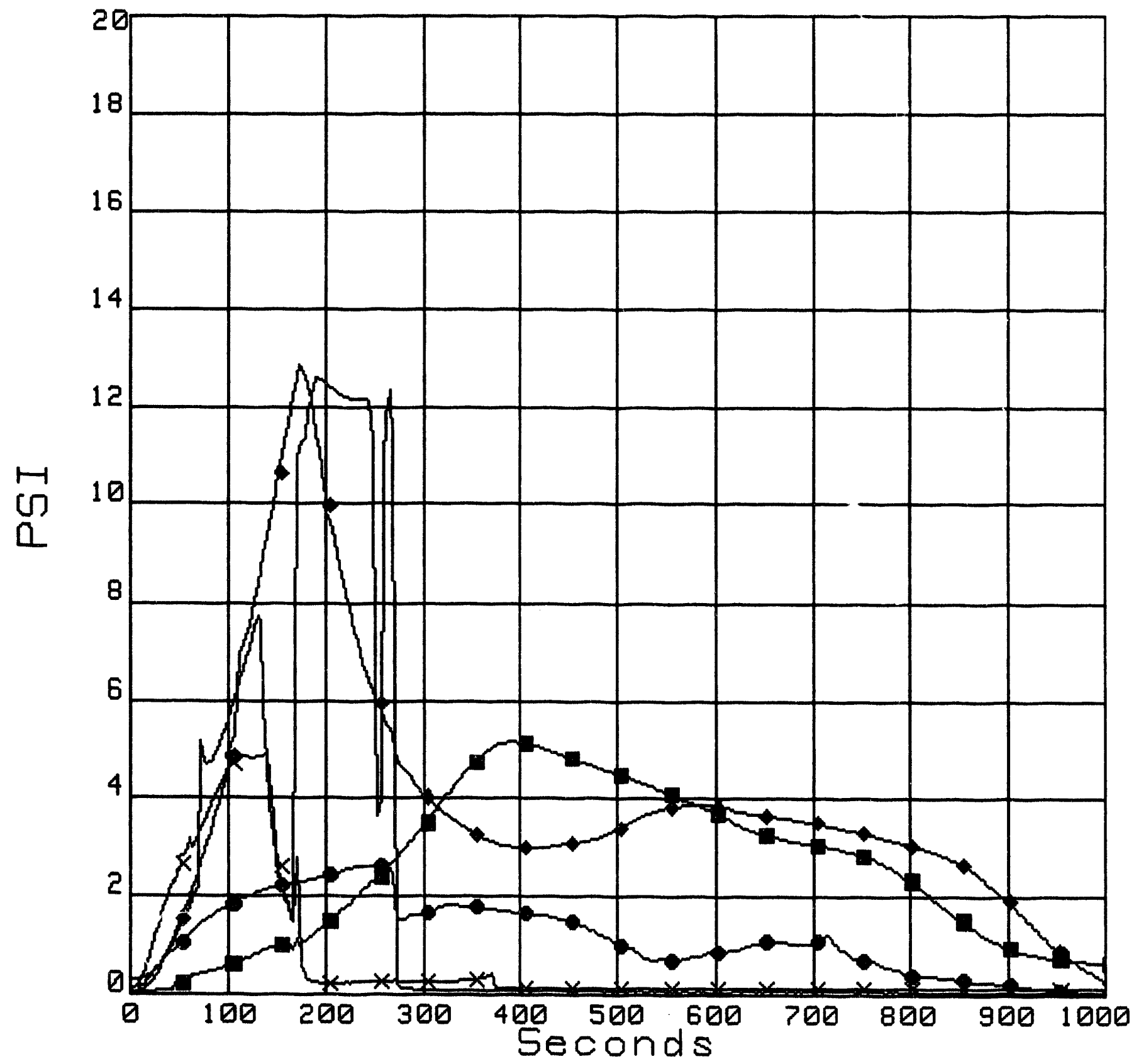

Figure 9 
Date: 17 Jun 19

FILENAME CHANNEL LOCATION WDPAN3

- WDPAN3

$\times$ WDPAN3

- WDPRN3

- WDPAN3

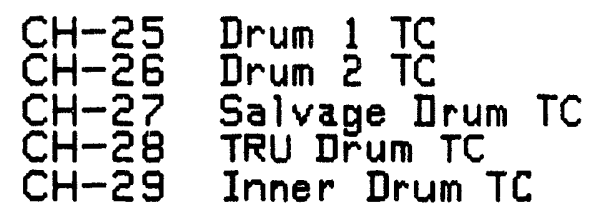

Time: 14:09:55 UNIT OF MEASURE SCALE

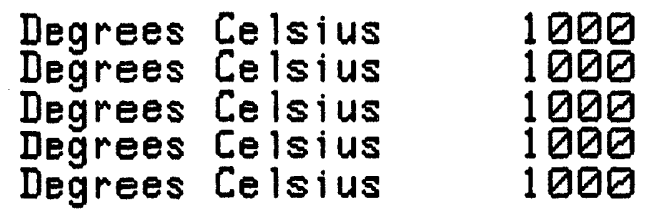

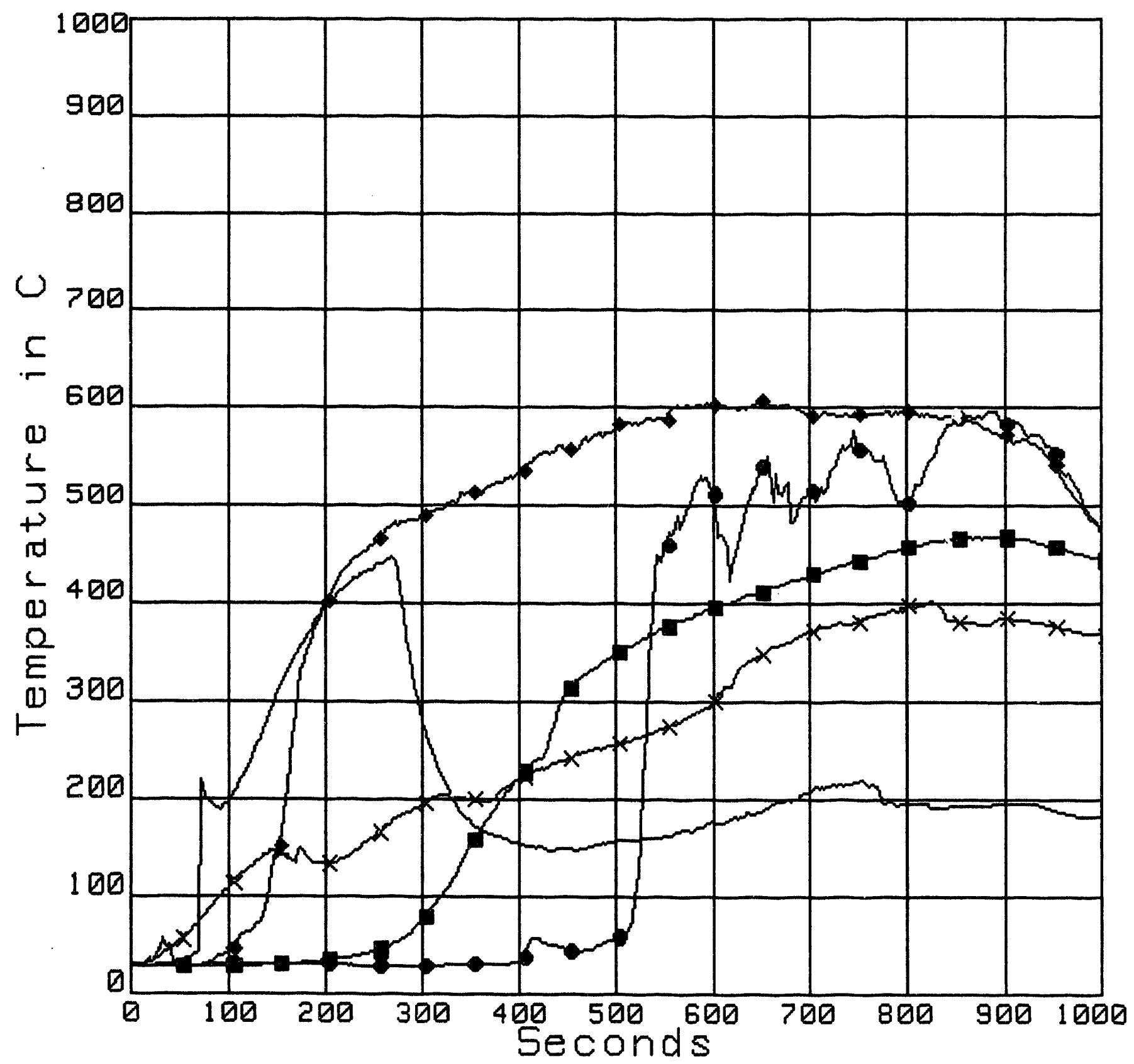

Figure 10 

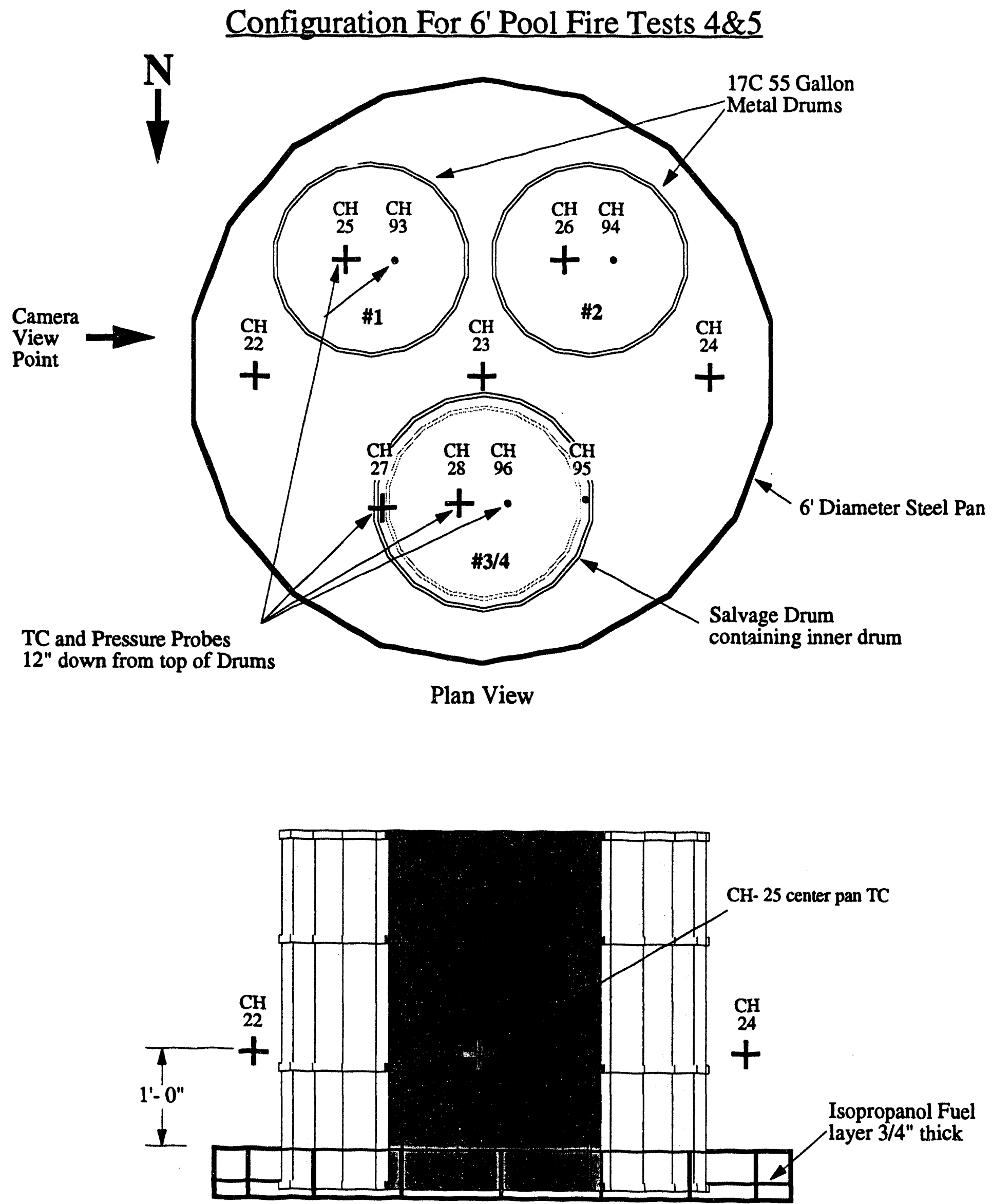
Date: 22 Jun 19

FILENAME CHANNEL LOCATION

WDPAN4

- WDPAN4

$\times$ WIPAN 4

- WDPRN4
CH-93 Drum 1 TD

CH-95 Salvage Drum TD

CH-96 Inner Drum
Time: $14: 41: 57$

UNIT OF MERSURE SCRLE

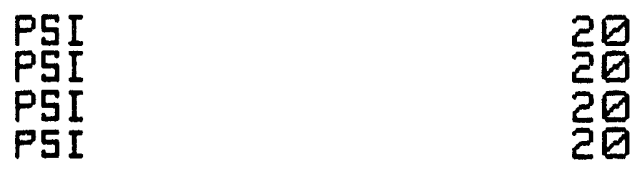

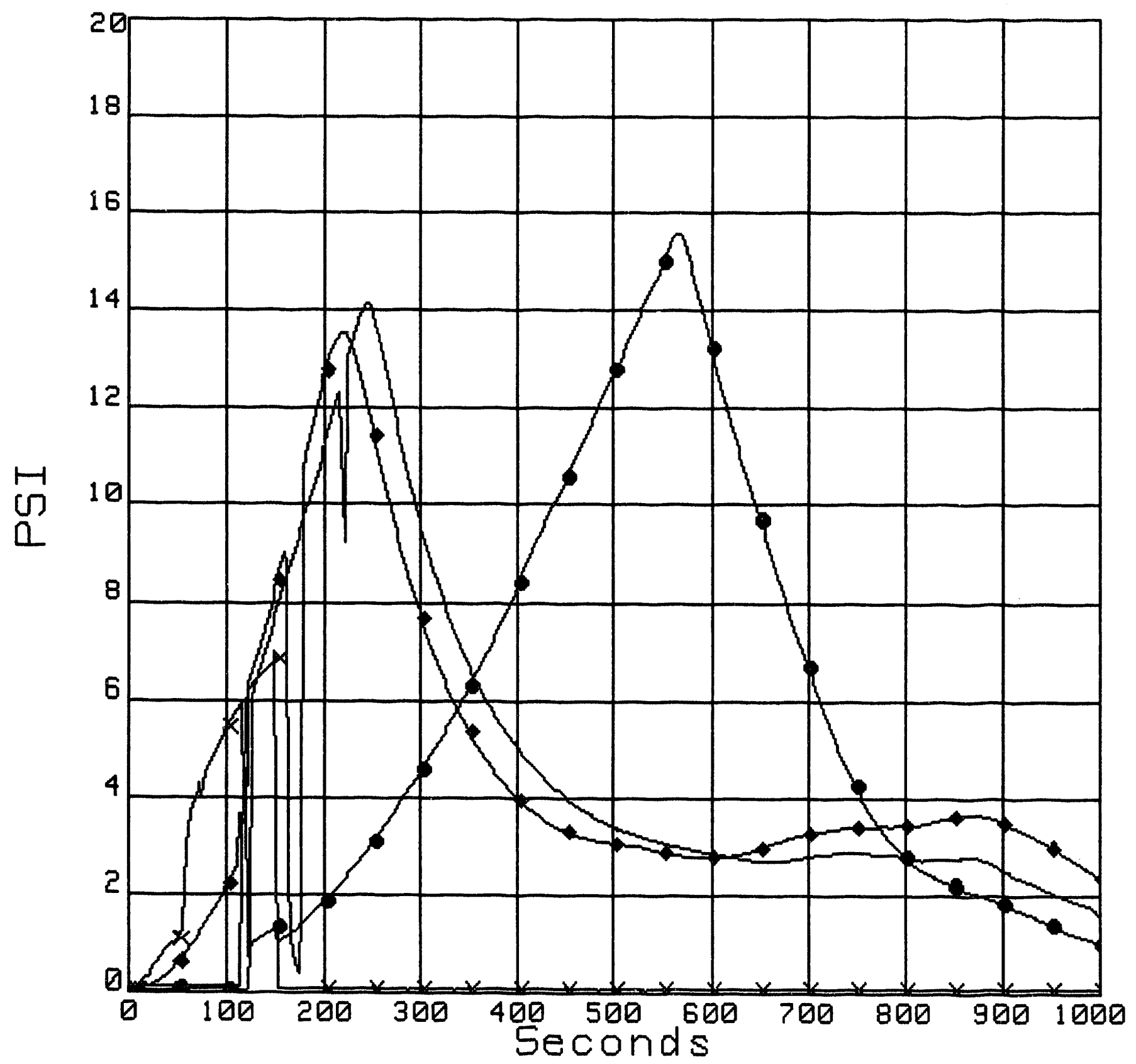

Figure 12 
Date: 22 Jun 19

FILENAME CHANNEL LOCATION

WDPRN4

- WDPAN4

$\times$ WDPAN4

- WDPRN4
CH-25 Drum 1 TC

$\mathrm{CH}-27$ Salvage Drum TC

$\mathrm{CH}-28$ Inner Irum
Time: $14: 41: 57$ UNIT OF MEASURE SCALE

Degrees Celsius 1000 Degrees Celsius 1000 Degrees Celsius 1000 Degrees Celsius 1000

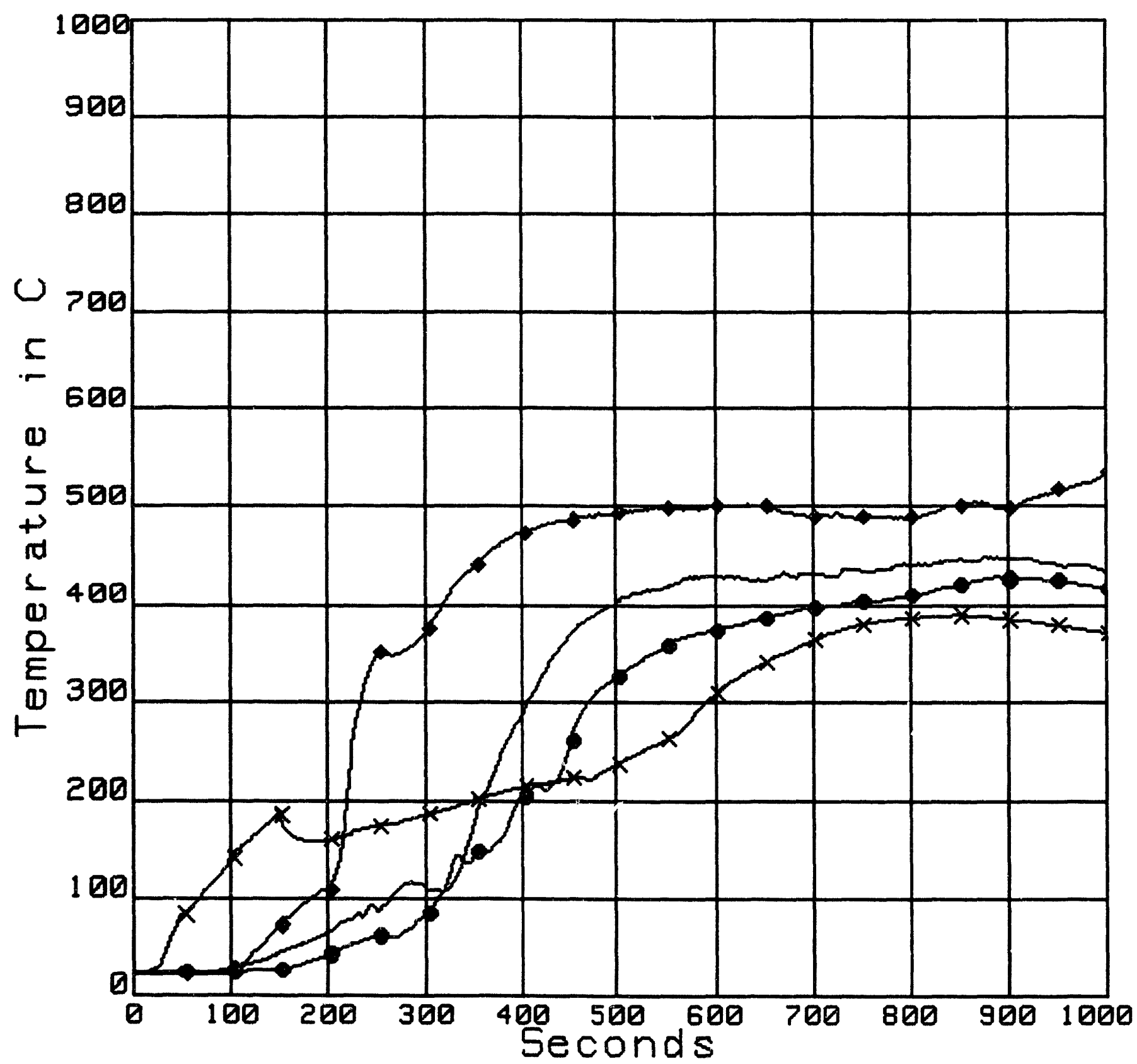

Figure 13 
Date: 25 Jun 19

FILENAME CHANNEL LOCATION

WDPAN5

- WDPAN5

$\times$ WDPAN5

- WDPAN5
CH-93 Drum 1 T⿱

CH-95 Salvage Drum TD

$\mathrm{CH}-96$ Inner Drum
Time: 12:03:04 UNIT OF MEASURE SCALE

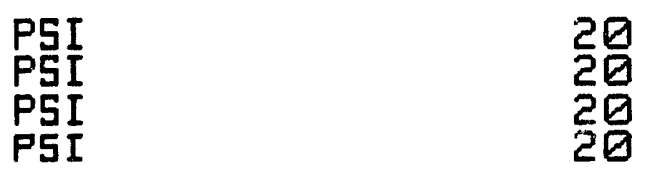

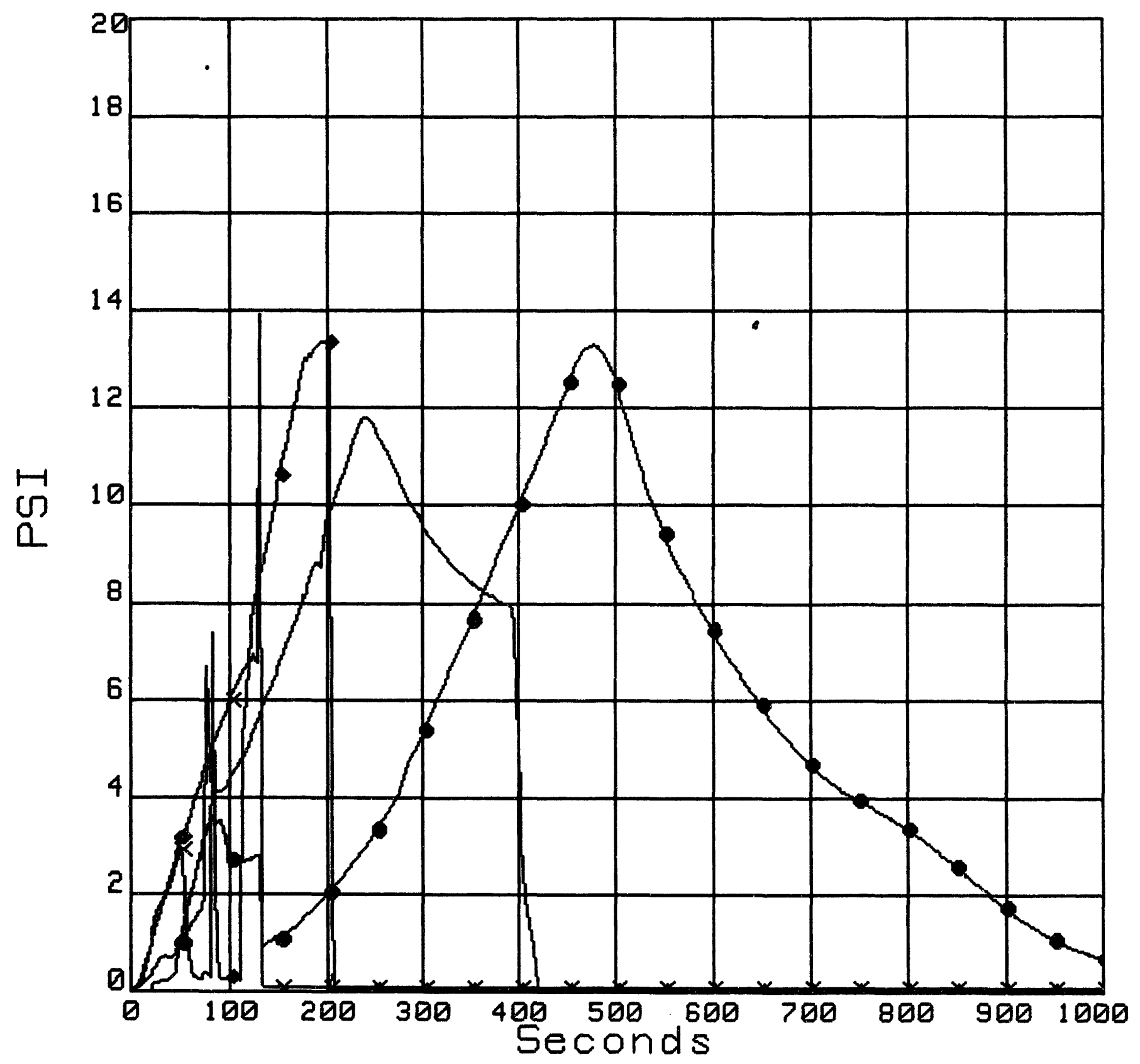

Figure 14 
Date: 25 Jun 19

FILENAME CHANNEL LOCATION

WDPAN5

- WDPAN5

$\times$ WDPAN5

- WDPAN5
CH-25 Drum 1 TC

$\mathrm{CH}-2$ ? Salvage Drum TC
Time: $12: 03: 04$ UNIT OF MERSURE SCRLE

Degrees Celsius

Degrees Ce isius

Degrees Celsius

Degrees Celsius
1000

100

1000

1000

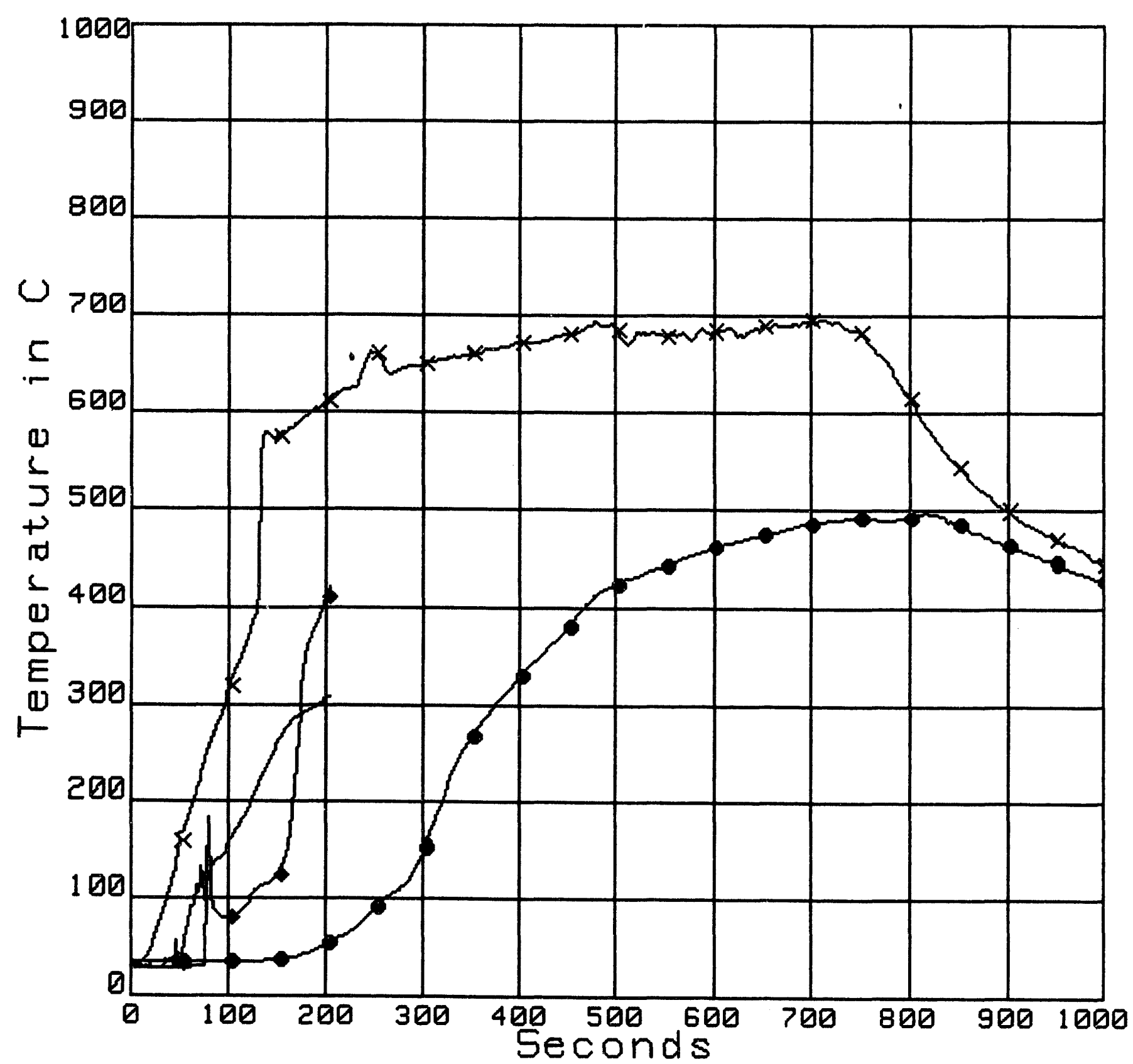

Figure 15 


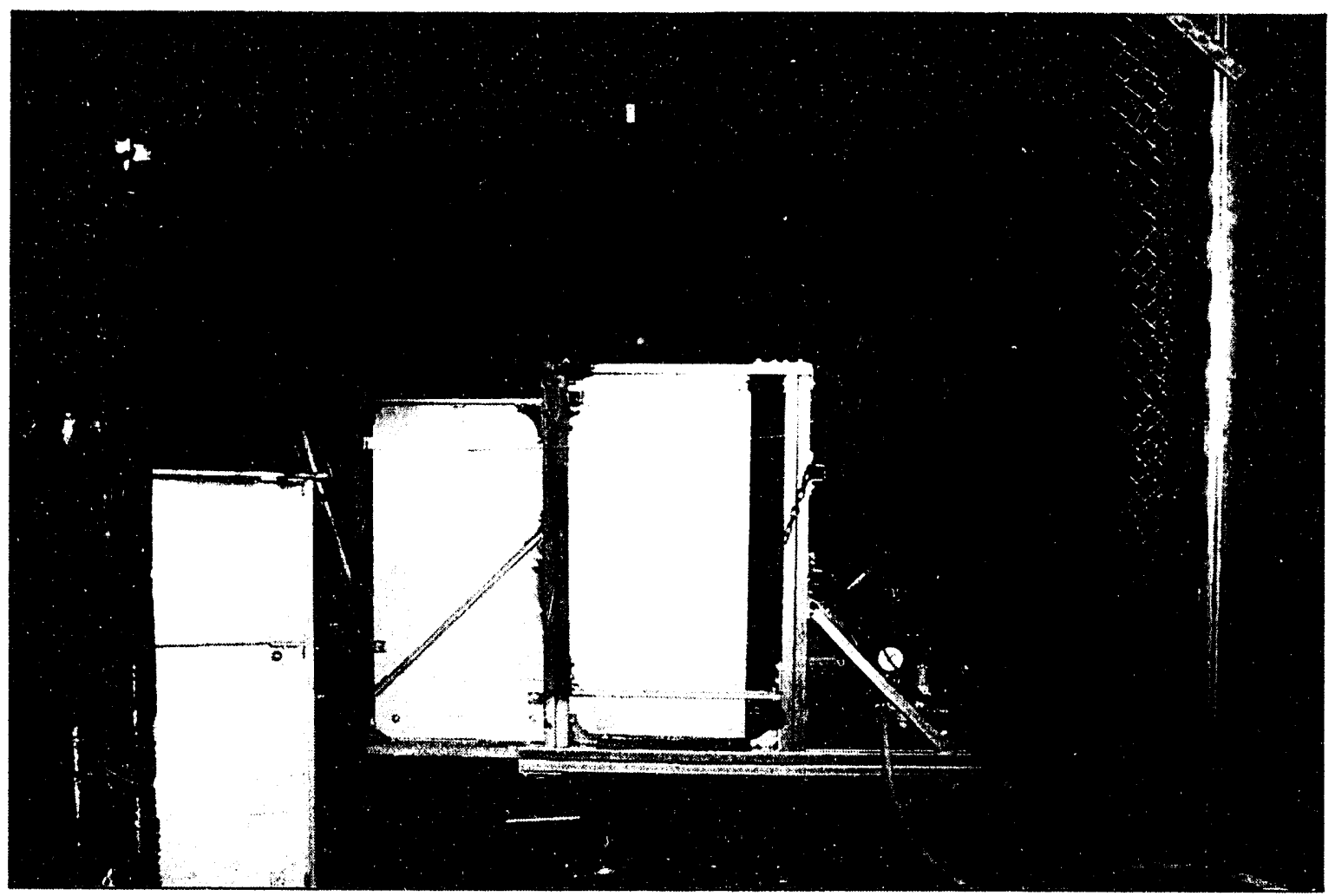

Photo 1: Overall view of WDE119A test set up, with the furnace in place.

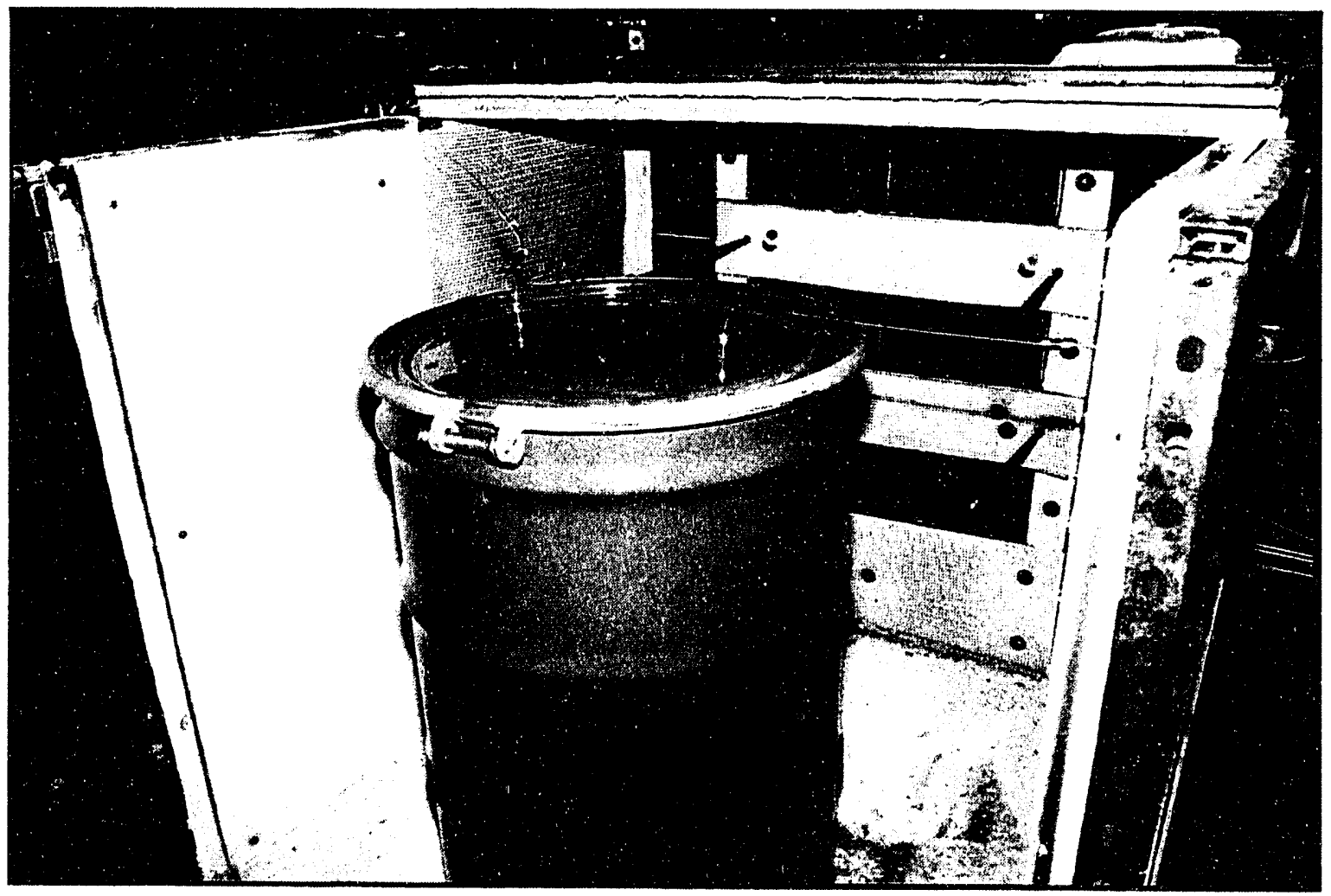

Photo 2: View of test drum in the furnace for WDE119A test. 


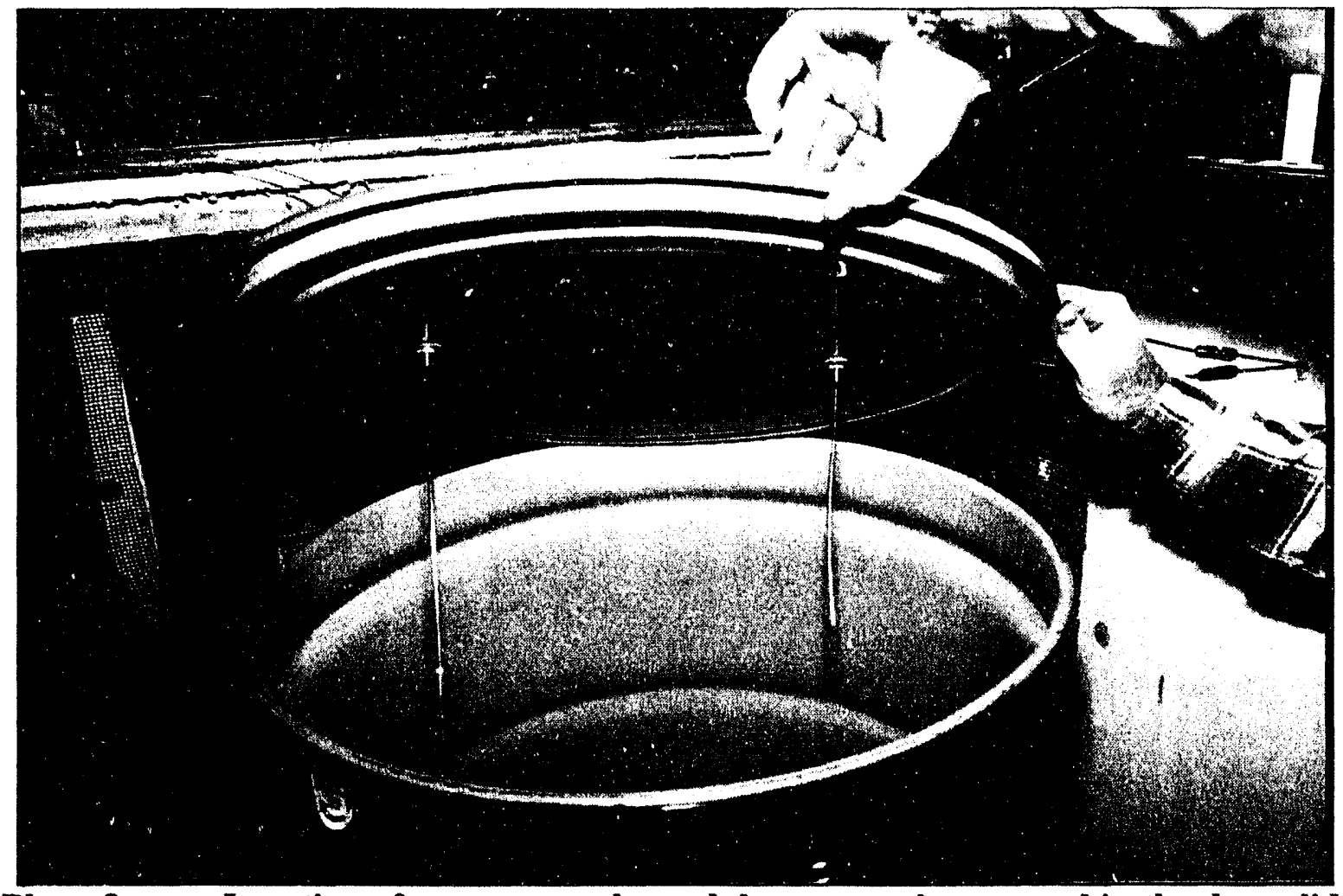

Photo 3:

Location of pressure probe and thermocouple mounted in the drum lid.

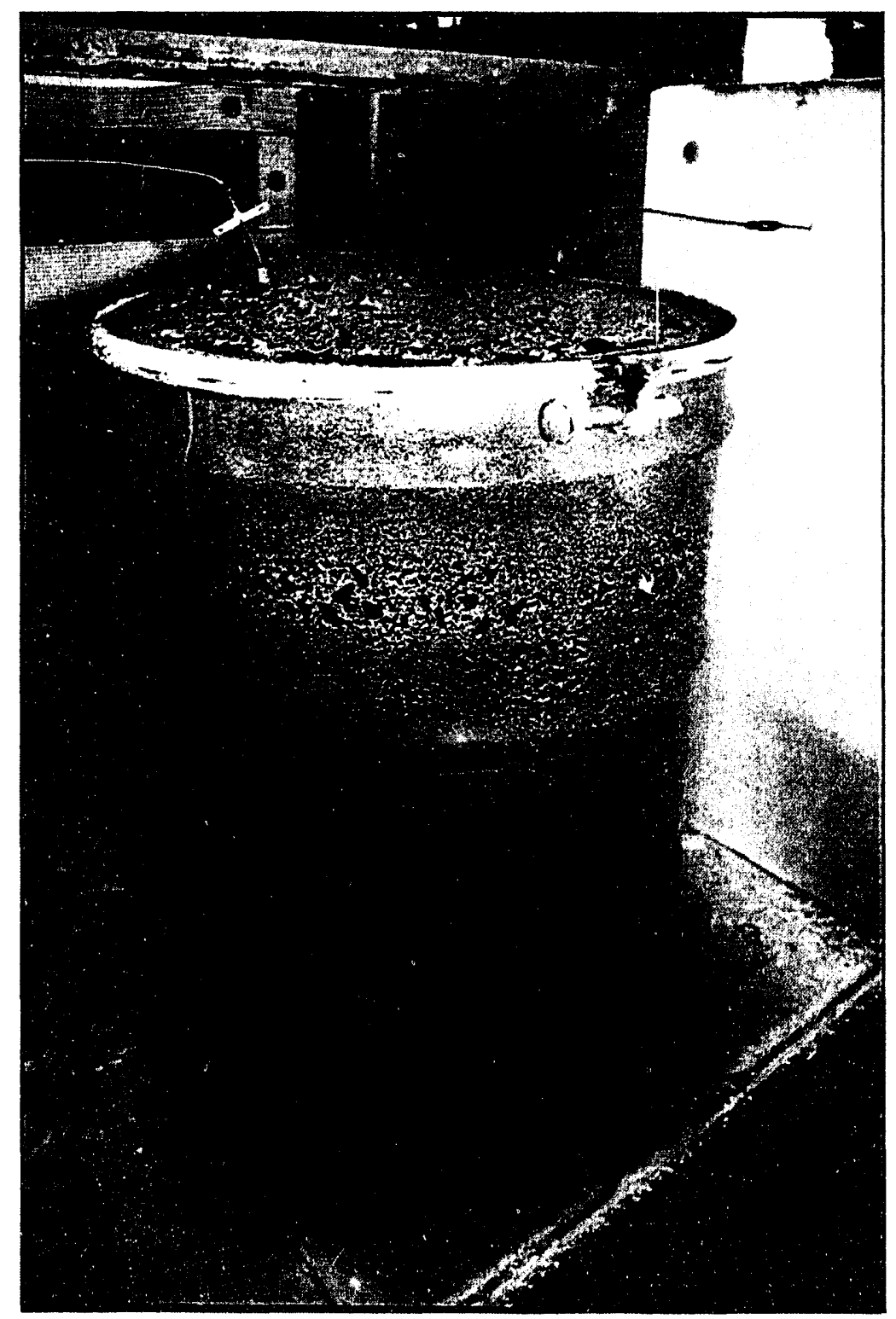

Photo 4: Overall view of the post test condition of the drum tested in WDE119A. 


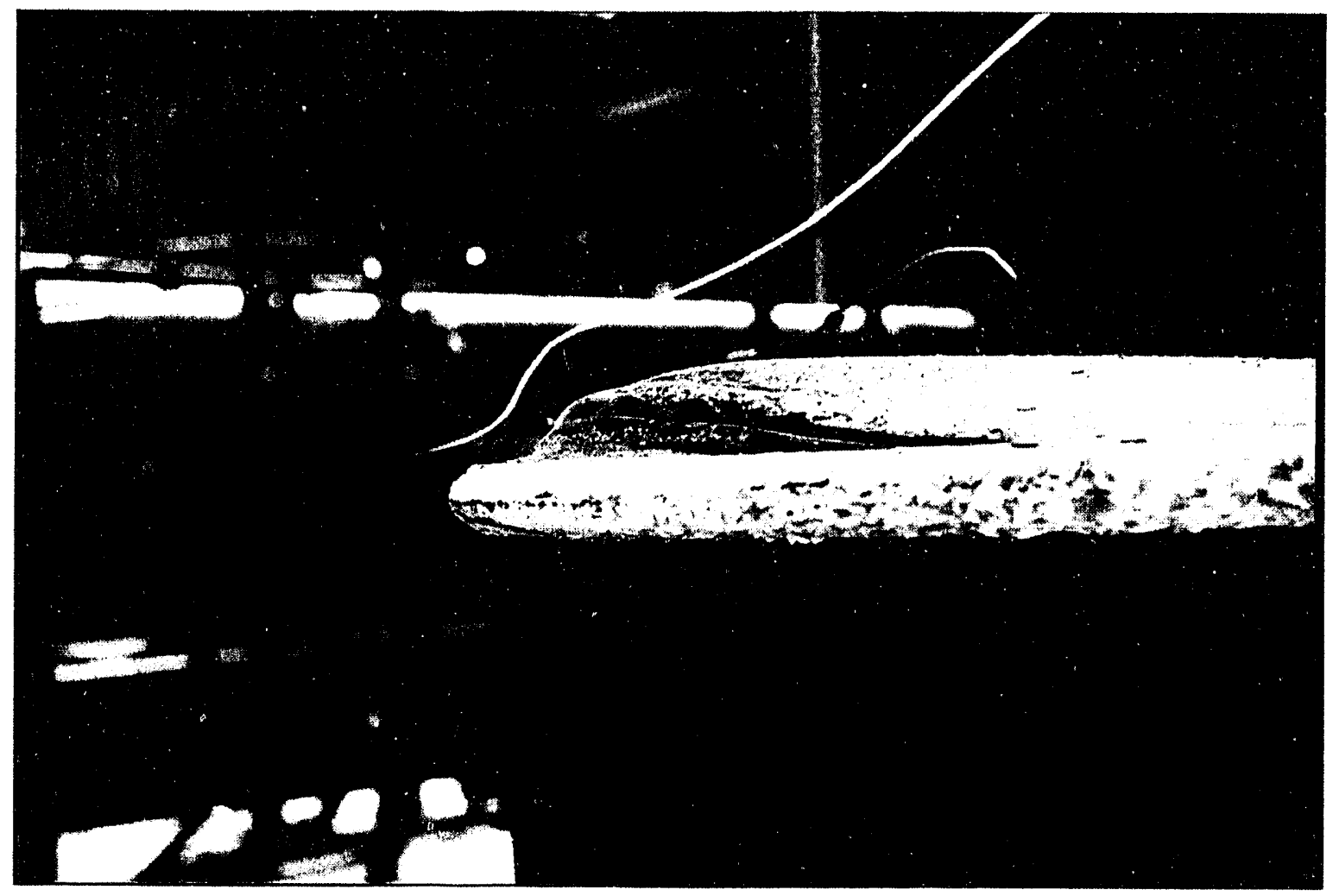

Photo 5: Close up view of the budge in the lid from the drum tested in WDE119A.

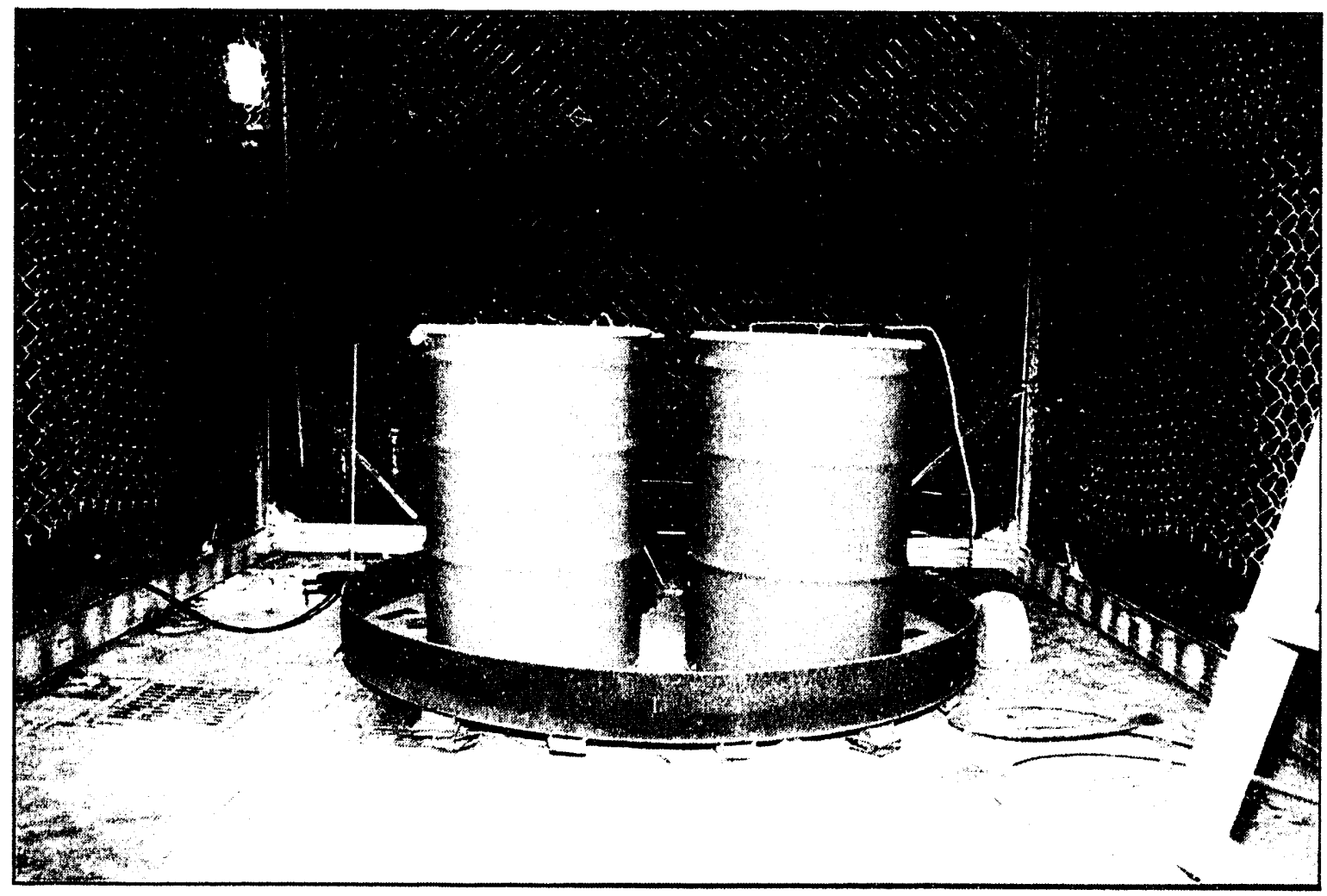

Photo 6: $\quad$ Overall view of set up used for Flammable Liquid Fire test WDPAN1. 


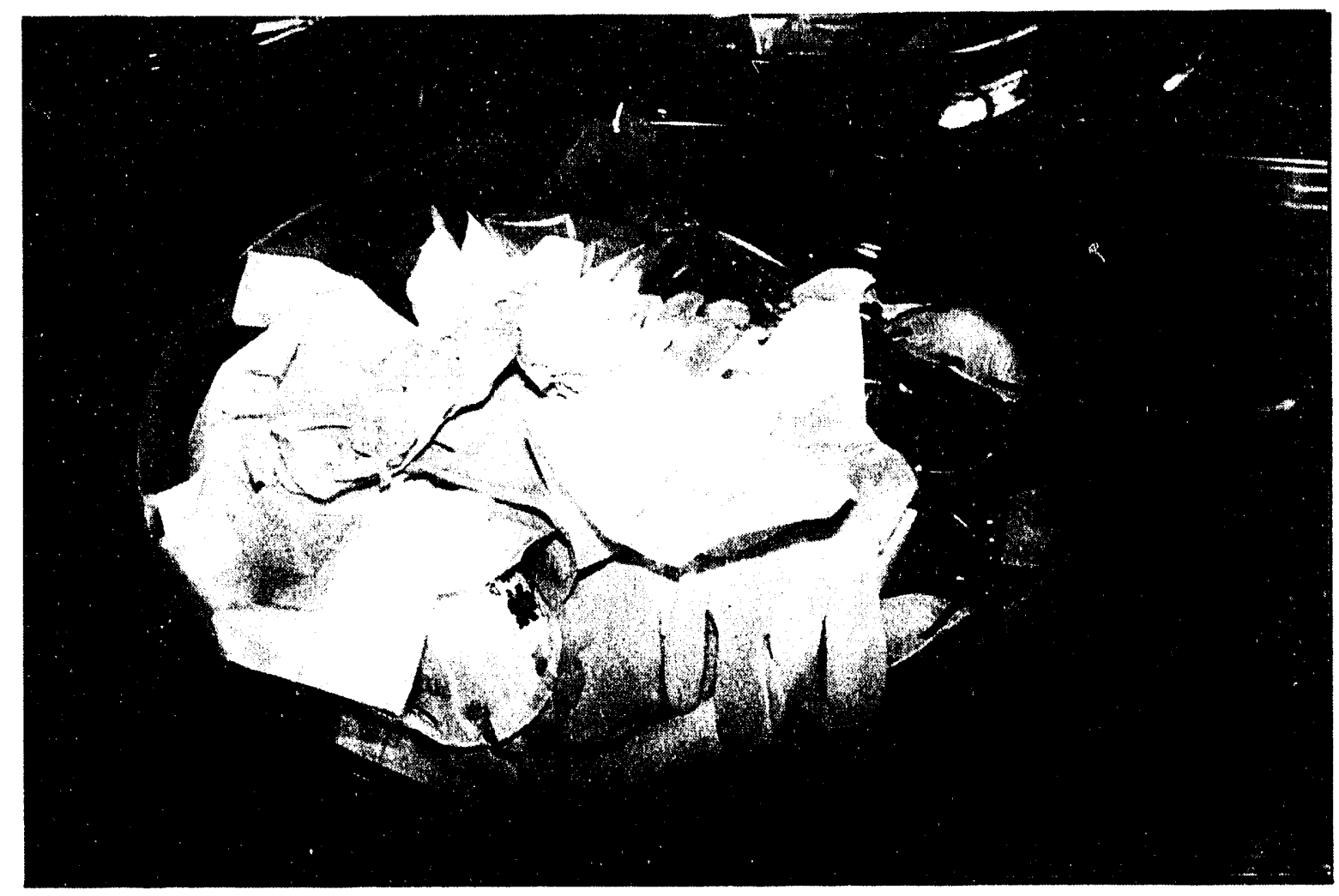

Photo 7: View of a drum with the standard loading used in test WDPAN1-5.

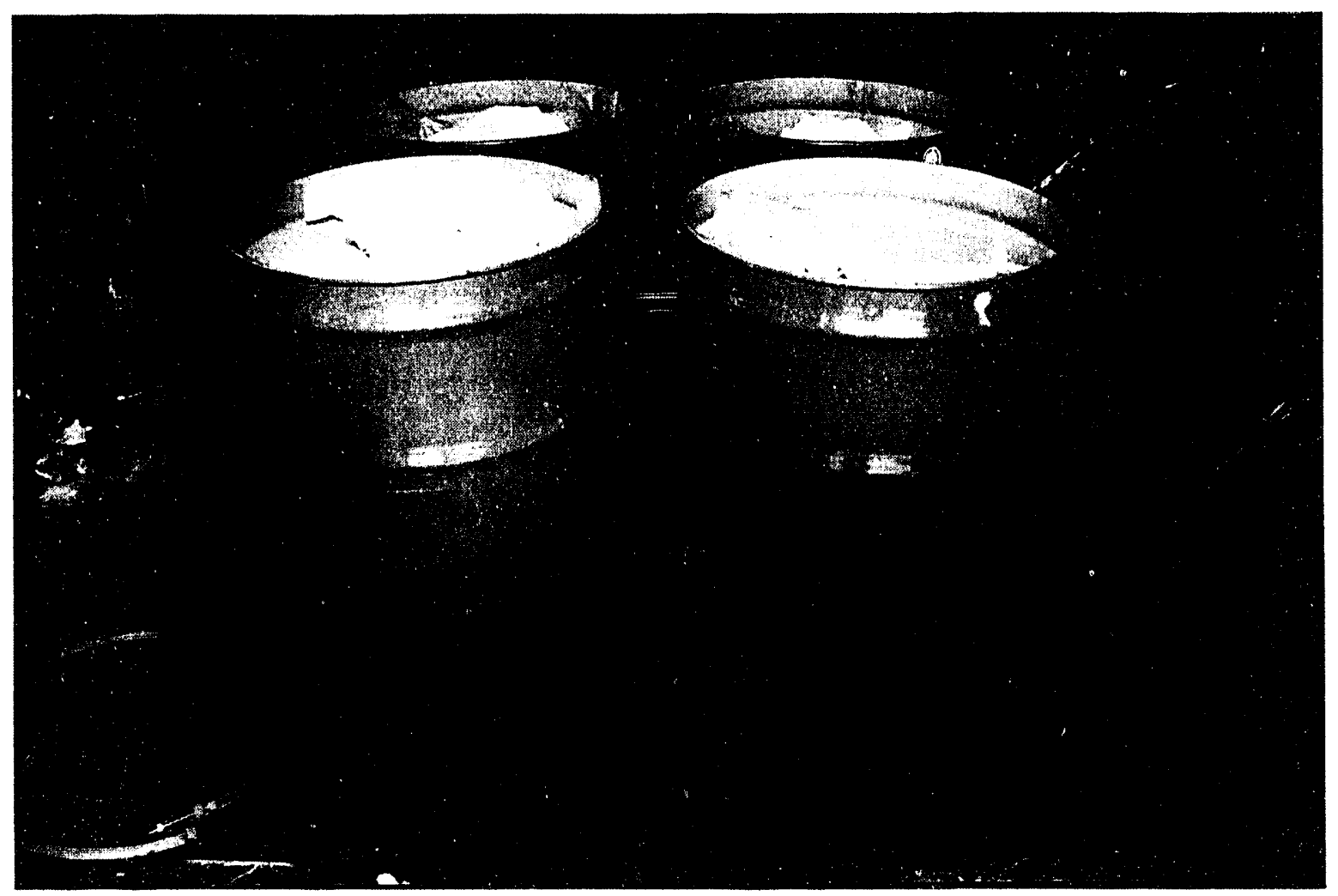

Photo 8: Overall view of drums showing standard loading and placement. 


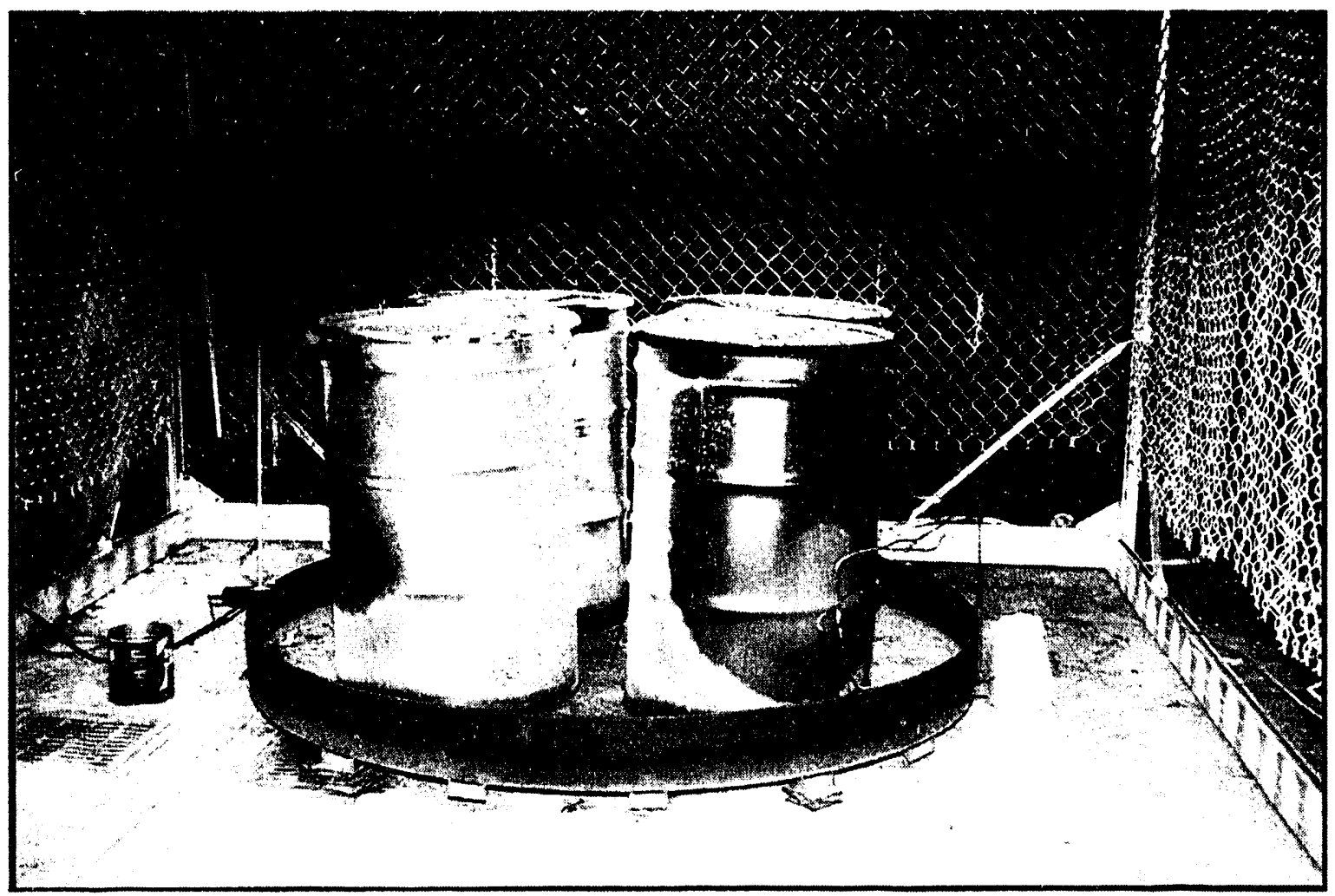

Photo 9: Condition of drums exposed to the alcohol fire from WDPAN1.

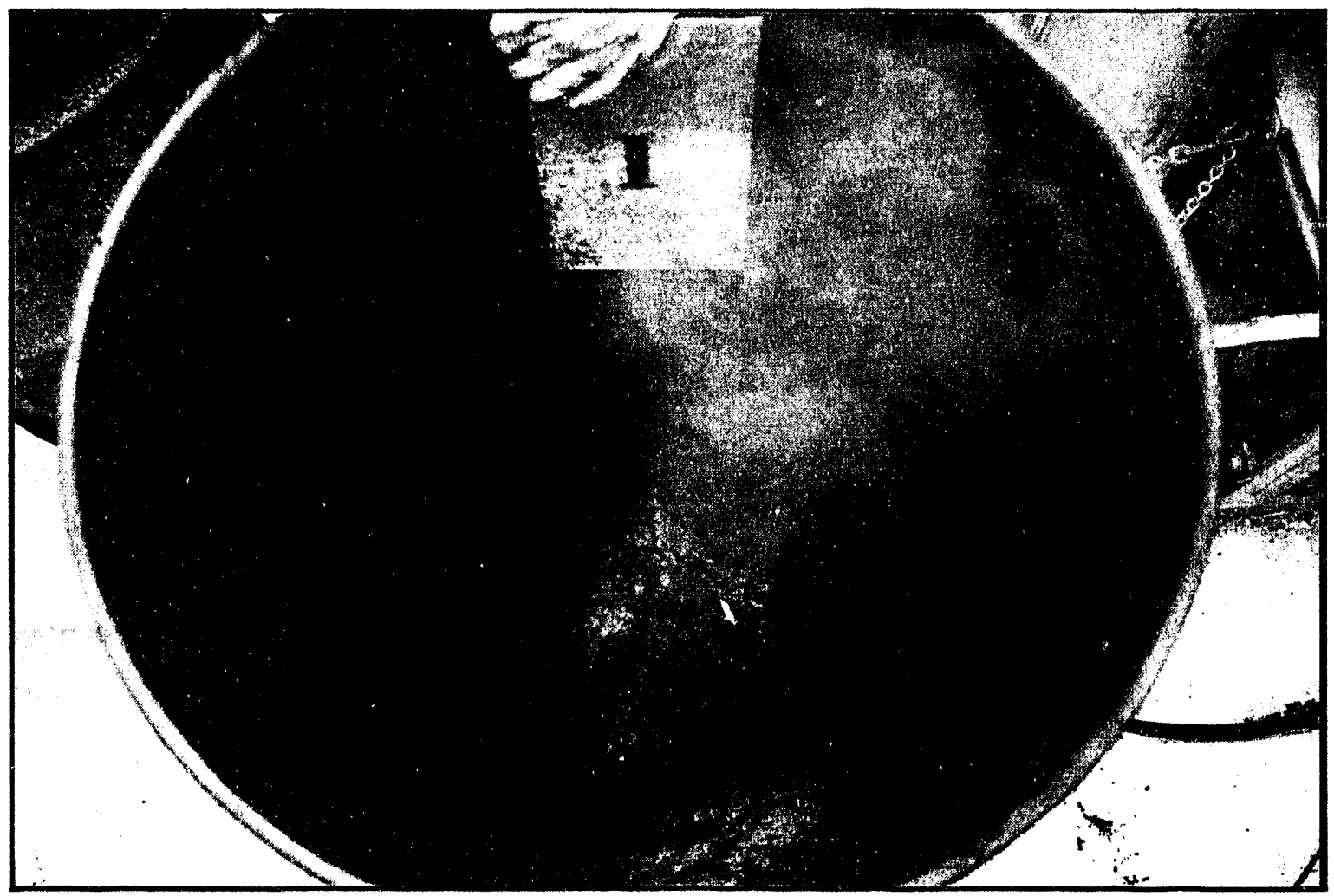

Photo 10: Condition of WDPAN1 drum 1 contents after the test fire. 


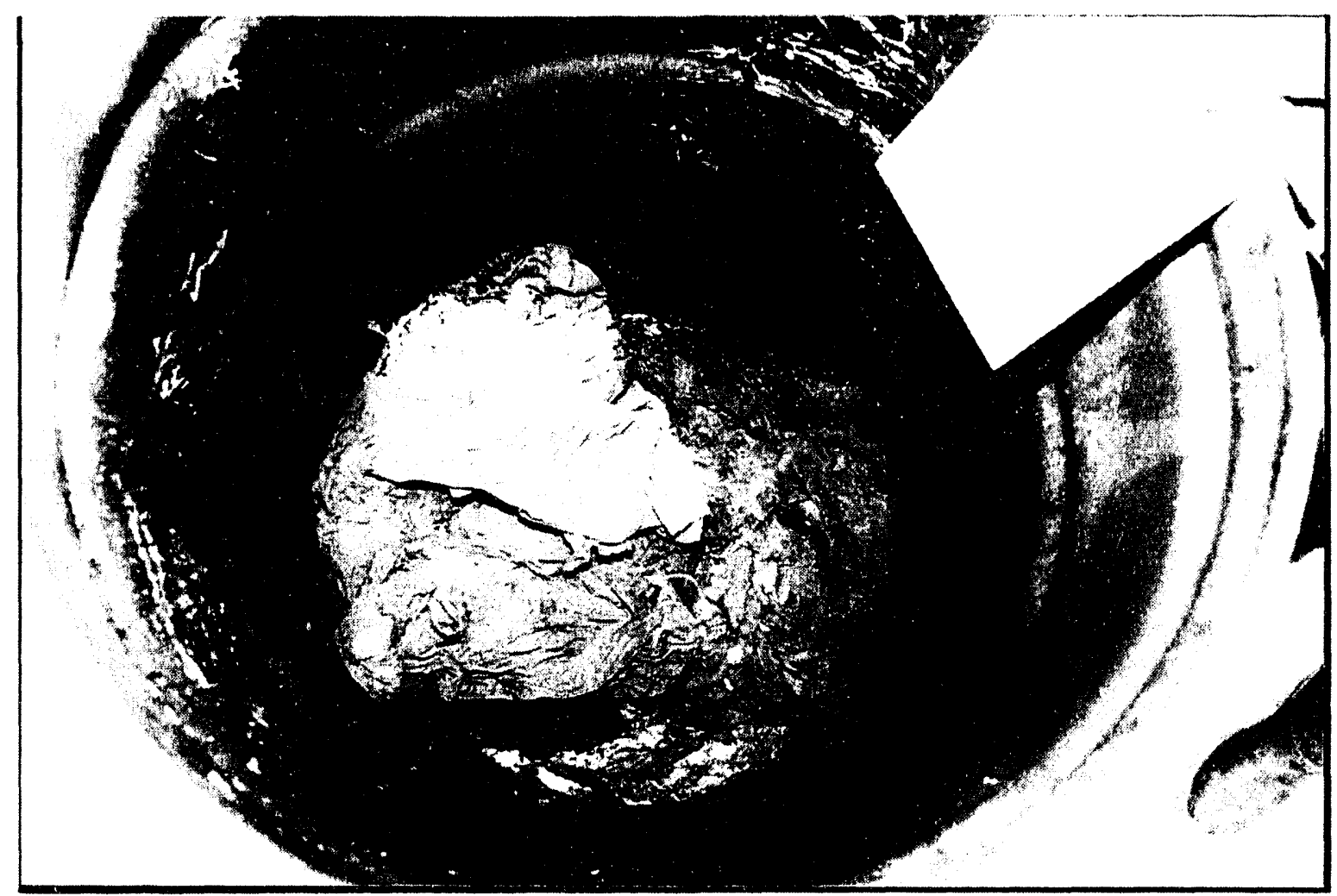

Photo 11: Condition of WDPAN1 drum 2 contents after the test fire.

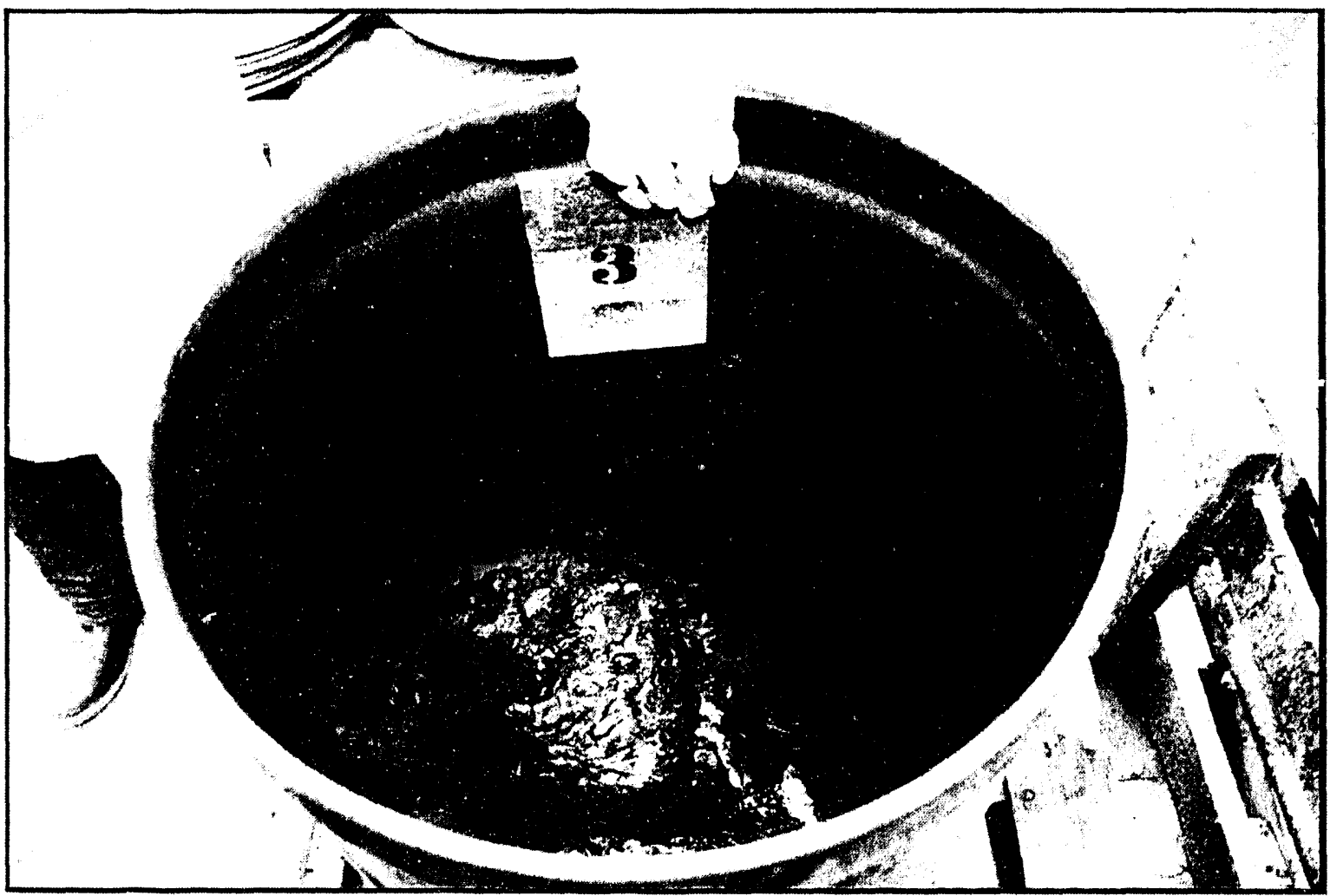

Photo 12: Condition of WDPAN1 drum 3 contents after the test fire. 


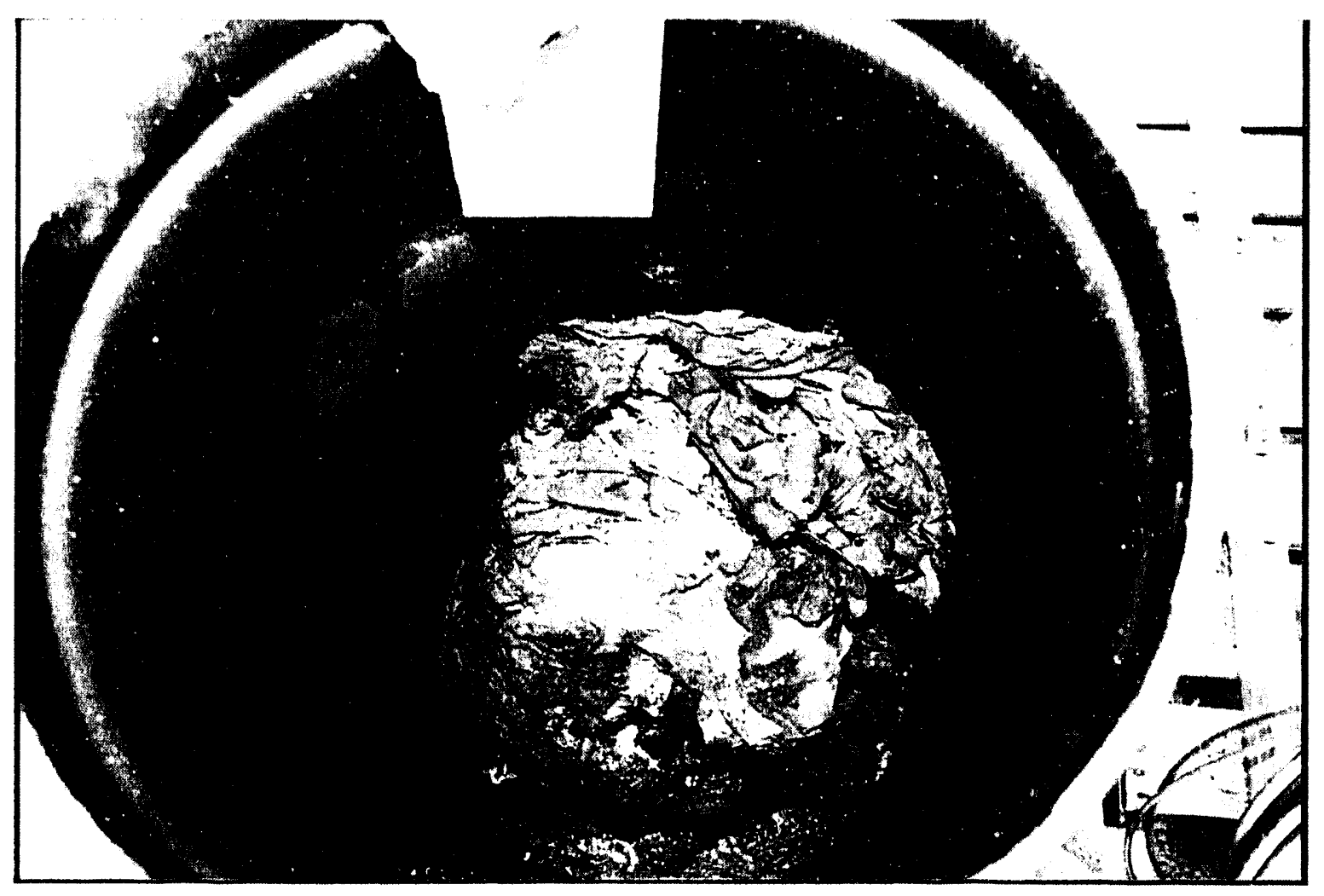

Photo 13: Condition of WDPAN1 drum 4 contents after the test fire.

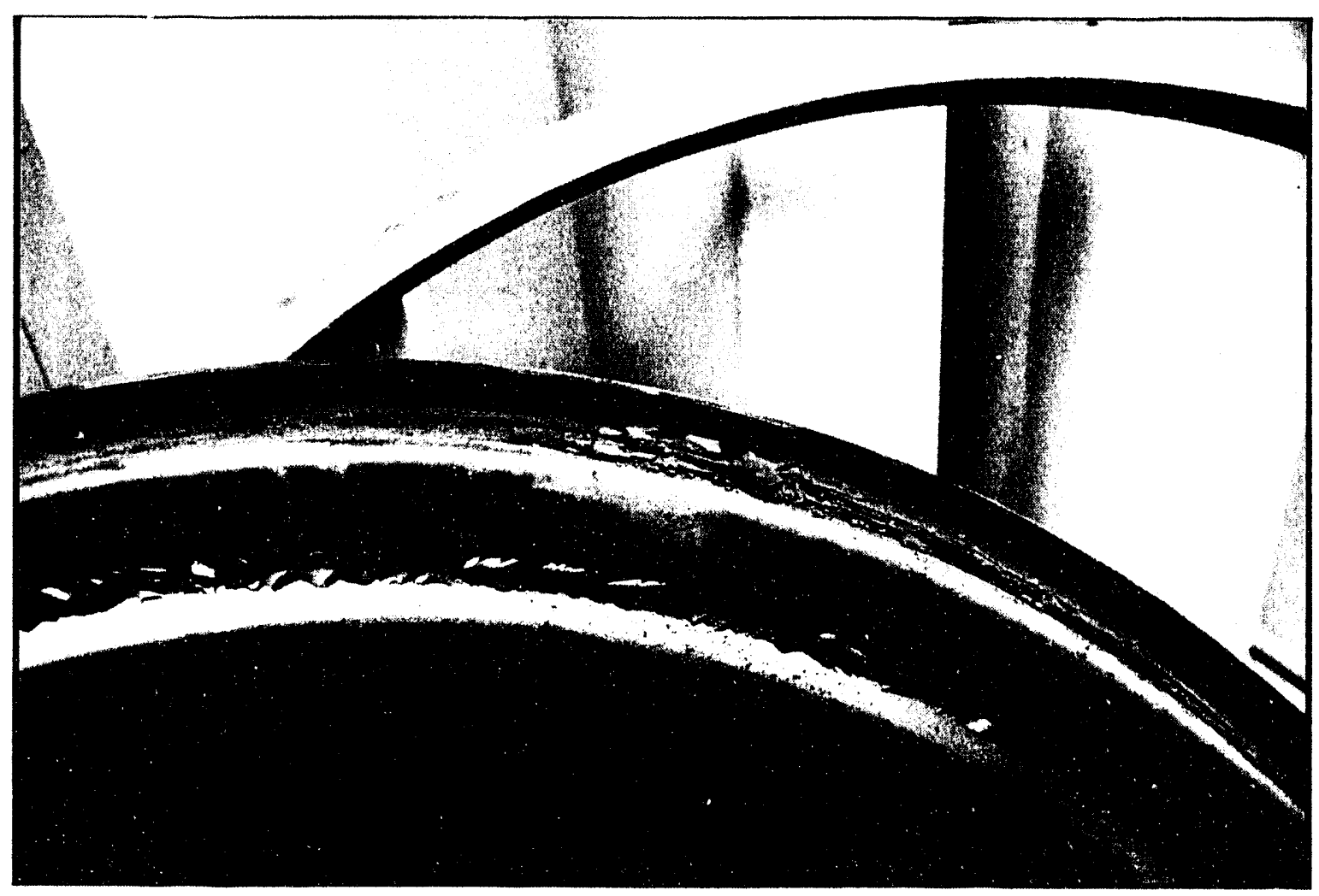

Photo 14: Charred remains of a lid seal from a drum tested in WDPAN1. 


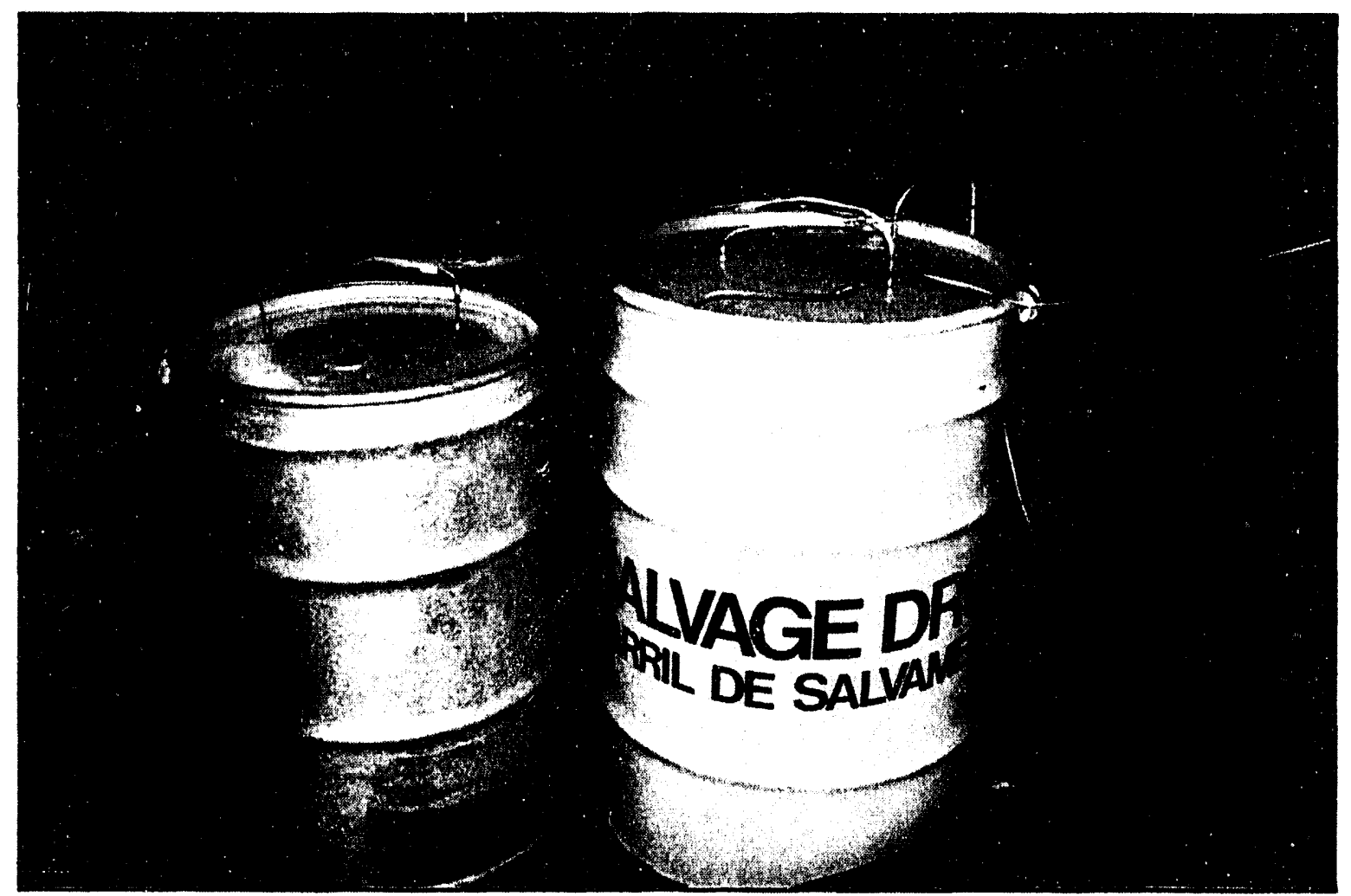

Photo 15: Overview of test set up for WDPAN2\&3.

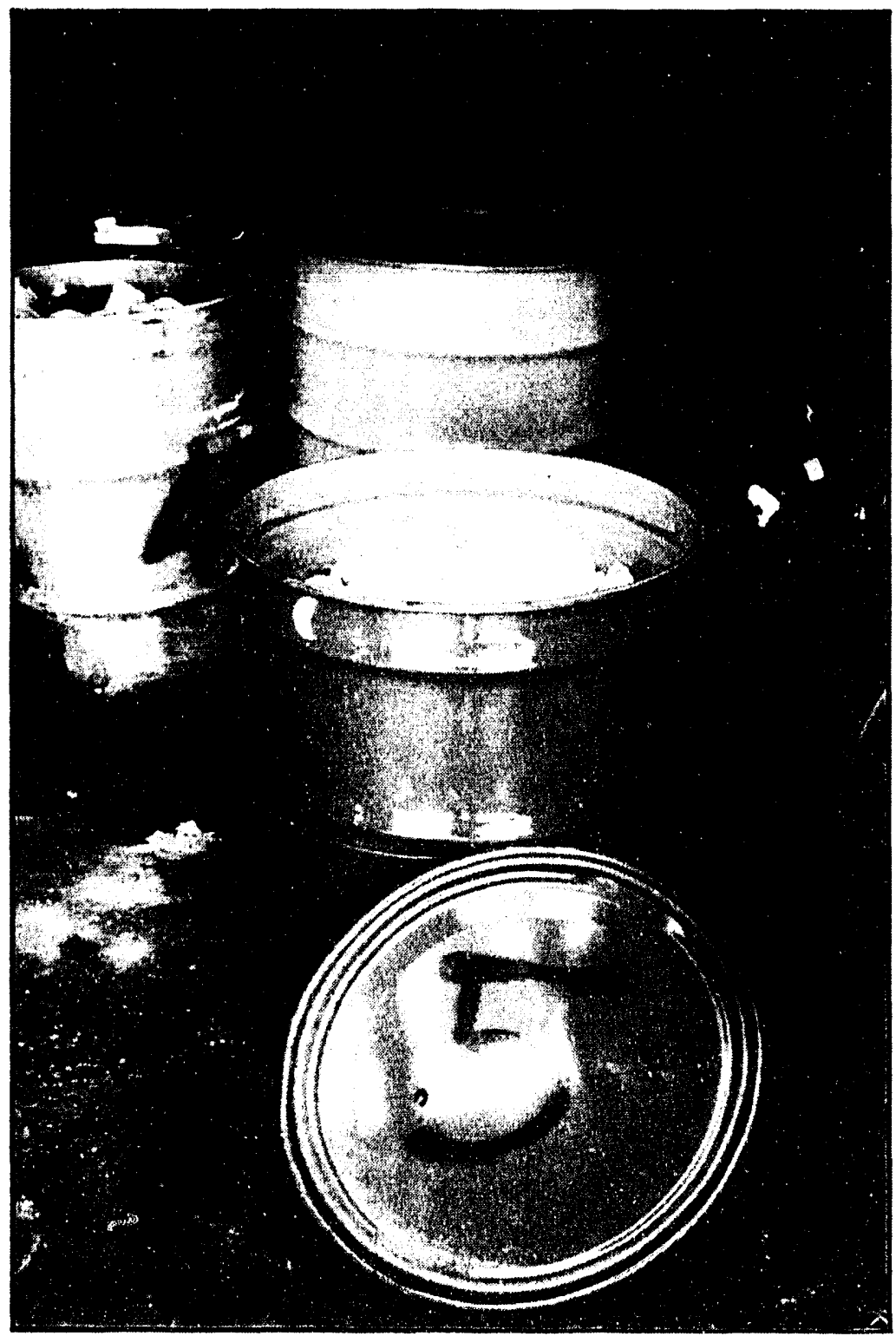

Photo 16: View of an inner drum, with standard loading, sealed inside a salvage drum. 


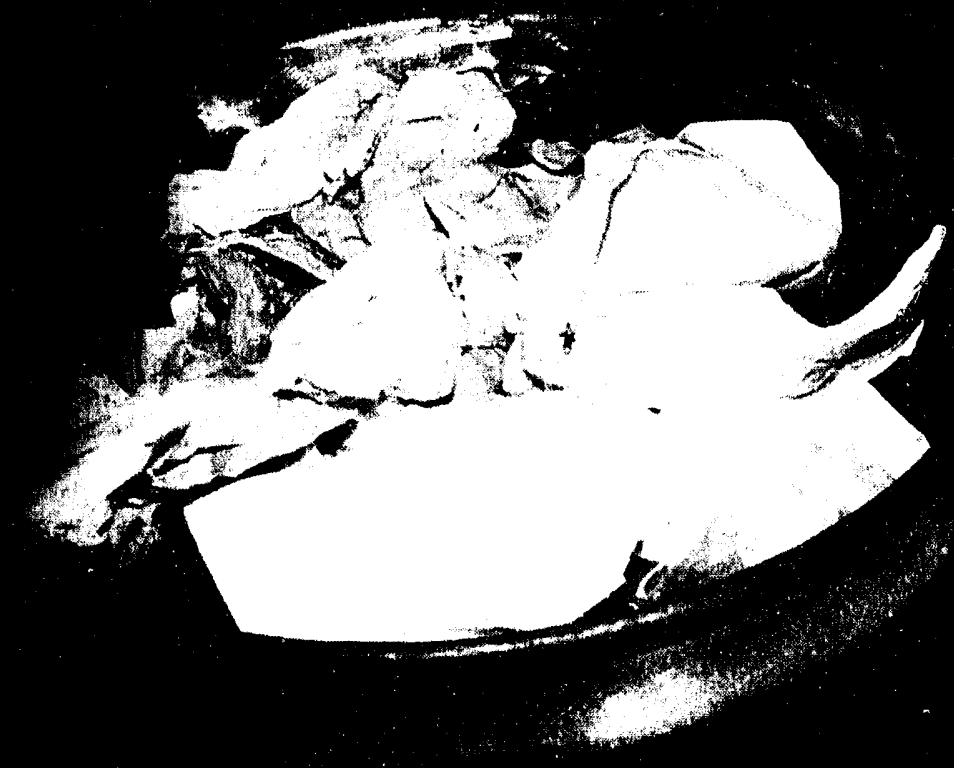

Photo 17: Standard loading of a TRU drum.

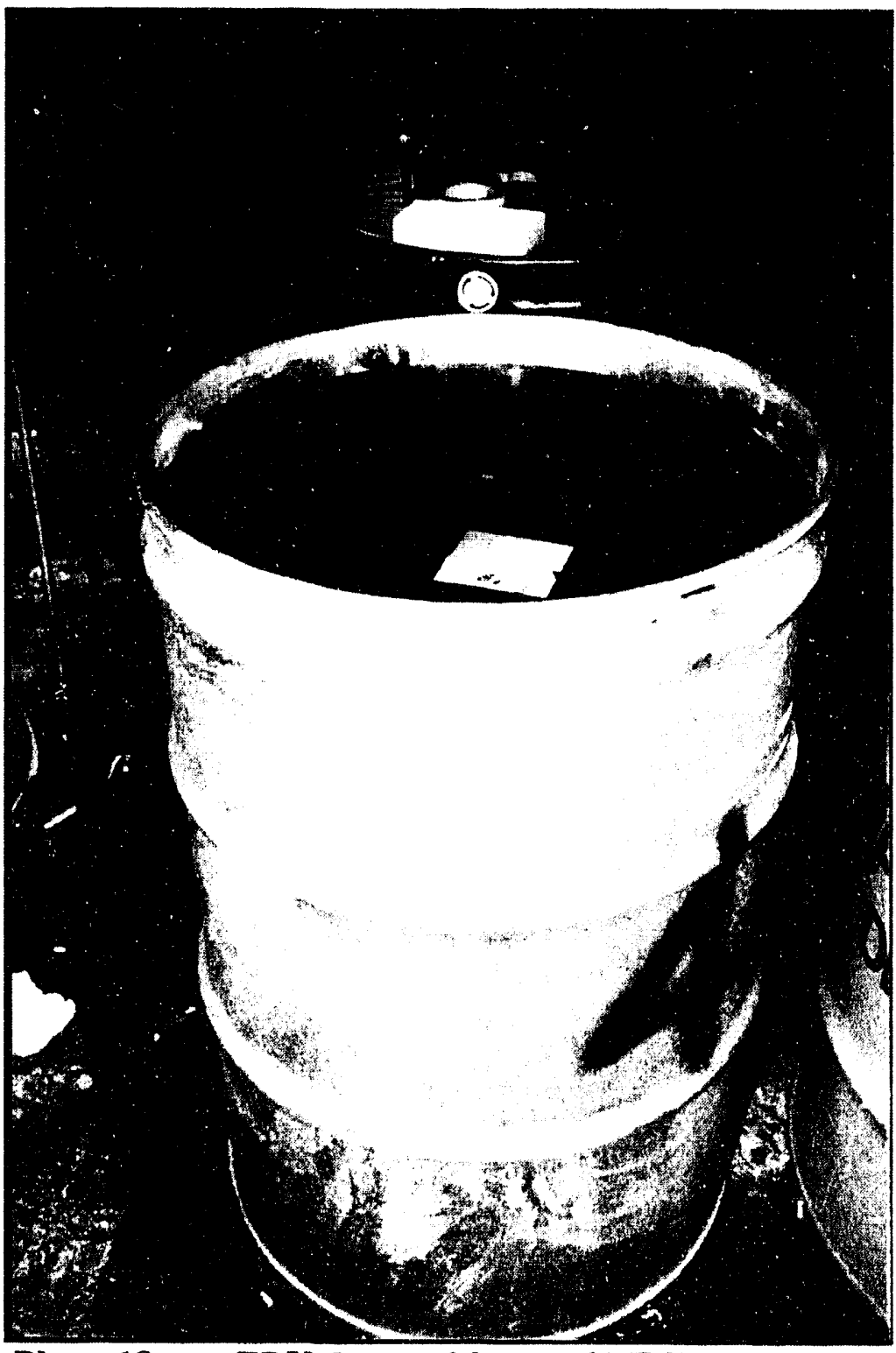

Photo 18: TRU drum with top of PE liner in place. 


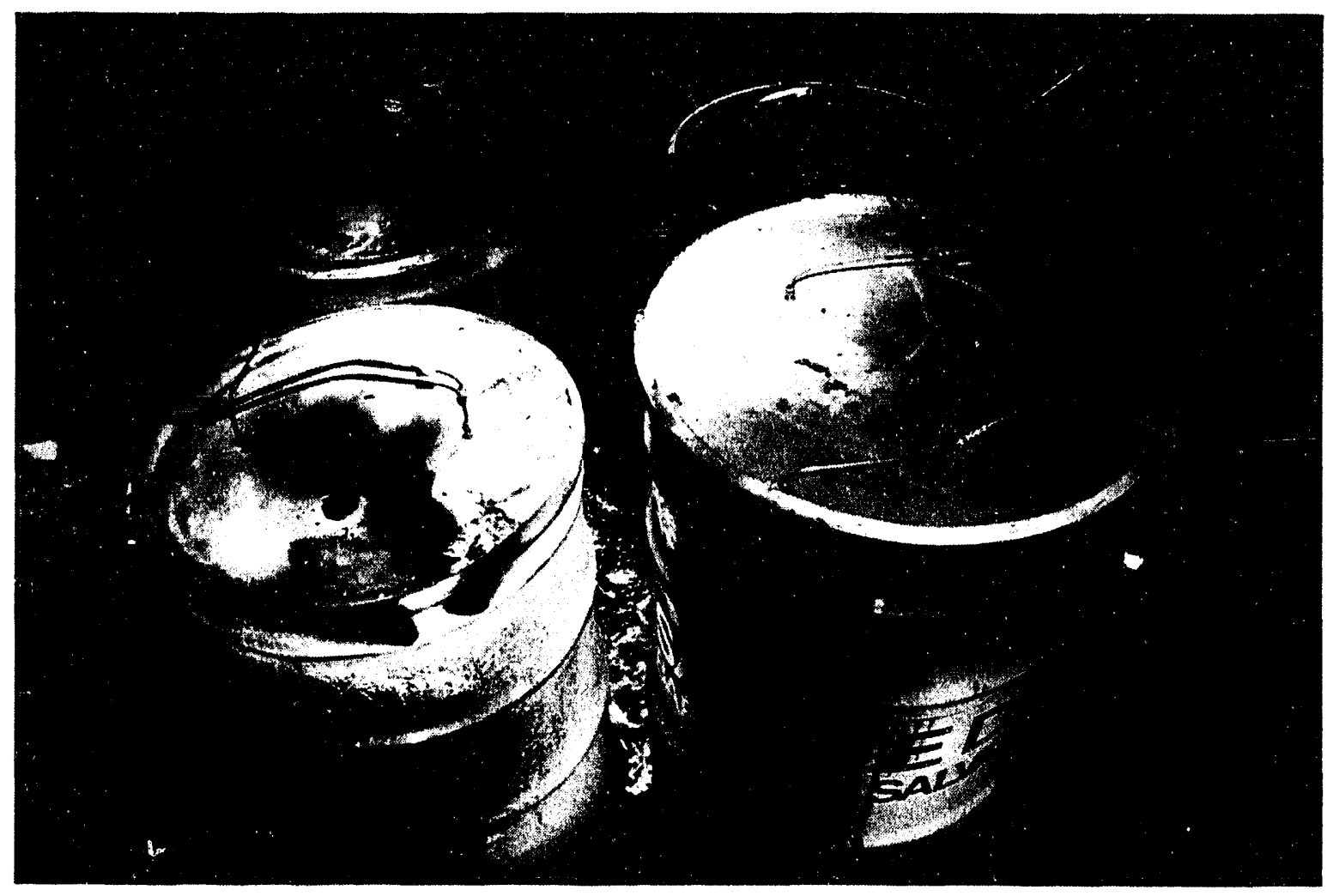

Photo 19: Post test condition of the drums tested in WDPAN2.

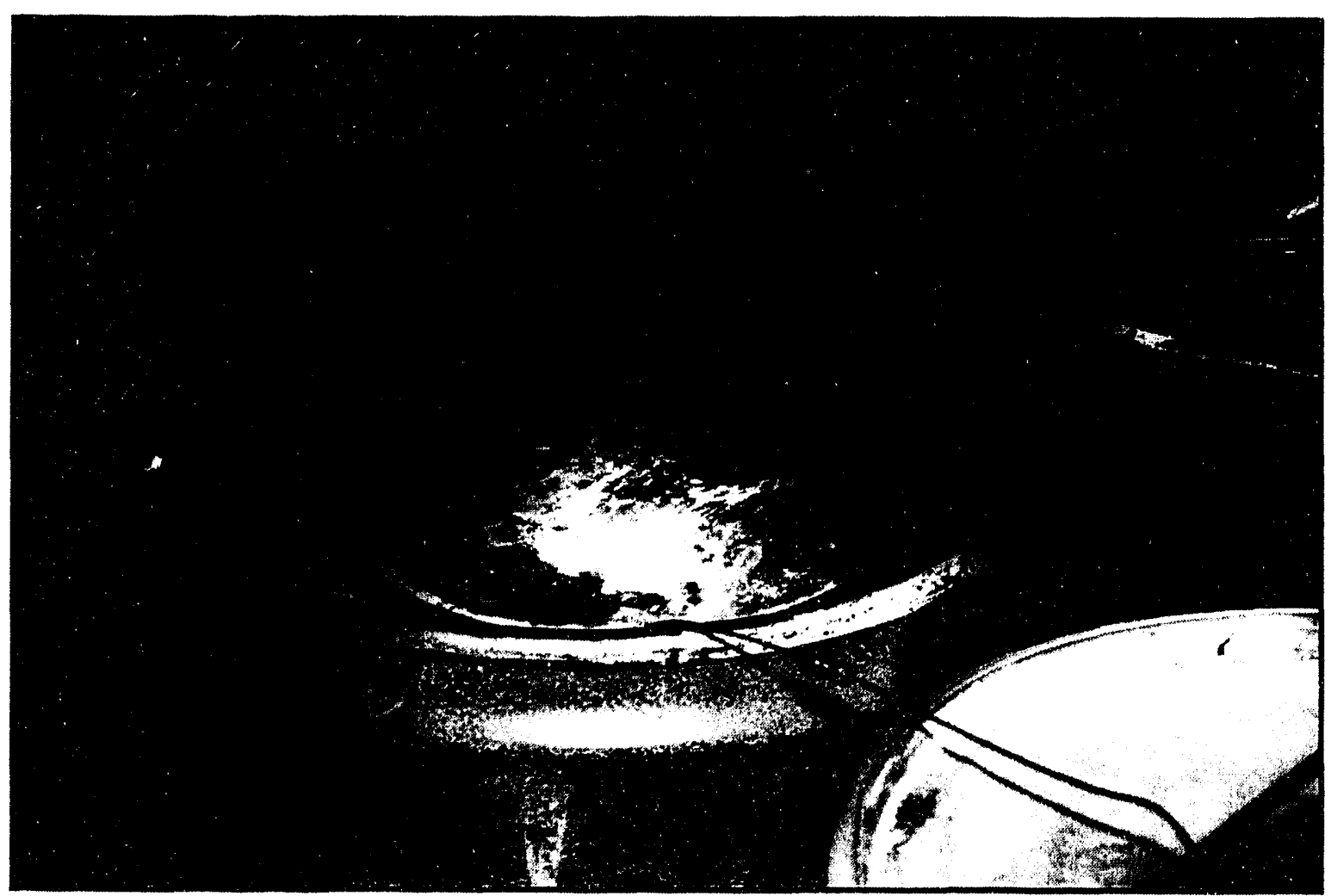

Photo 20: Post test condition and location of lid that blew off of drum 1 in test WDPAN2. 


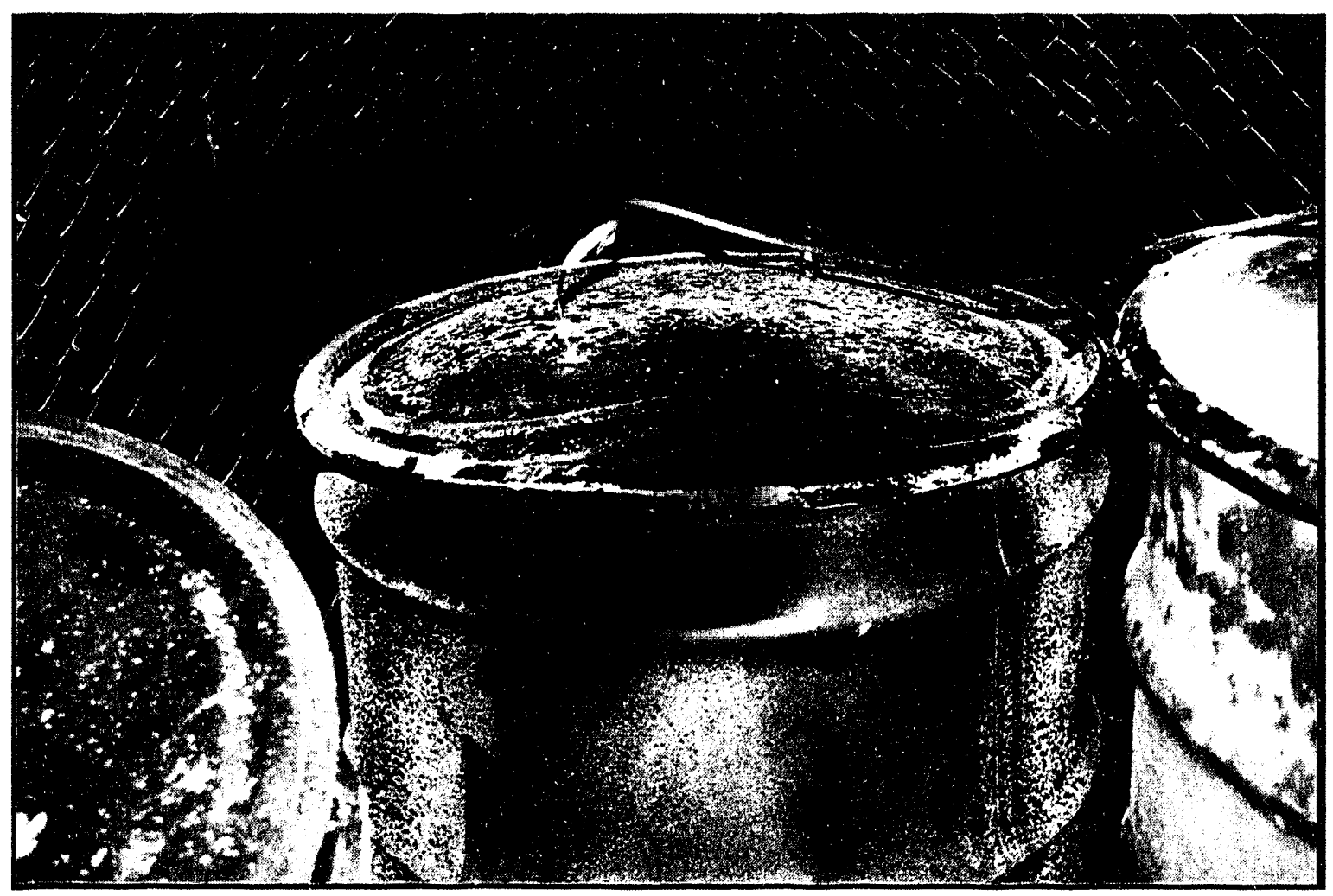

Photo 21: $\quad$ Post test condition of drum 2 tested in WDPAN2.

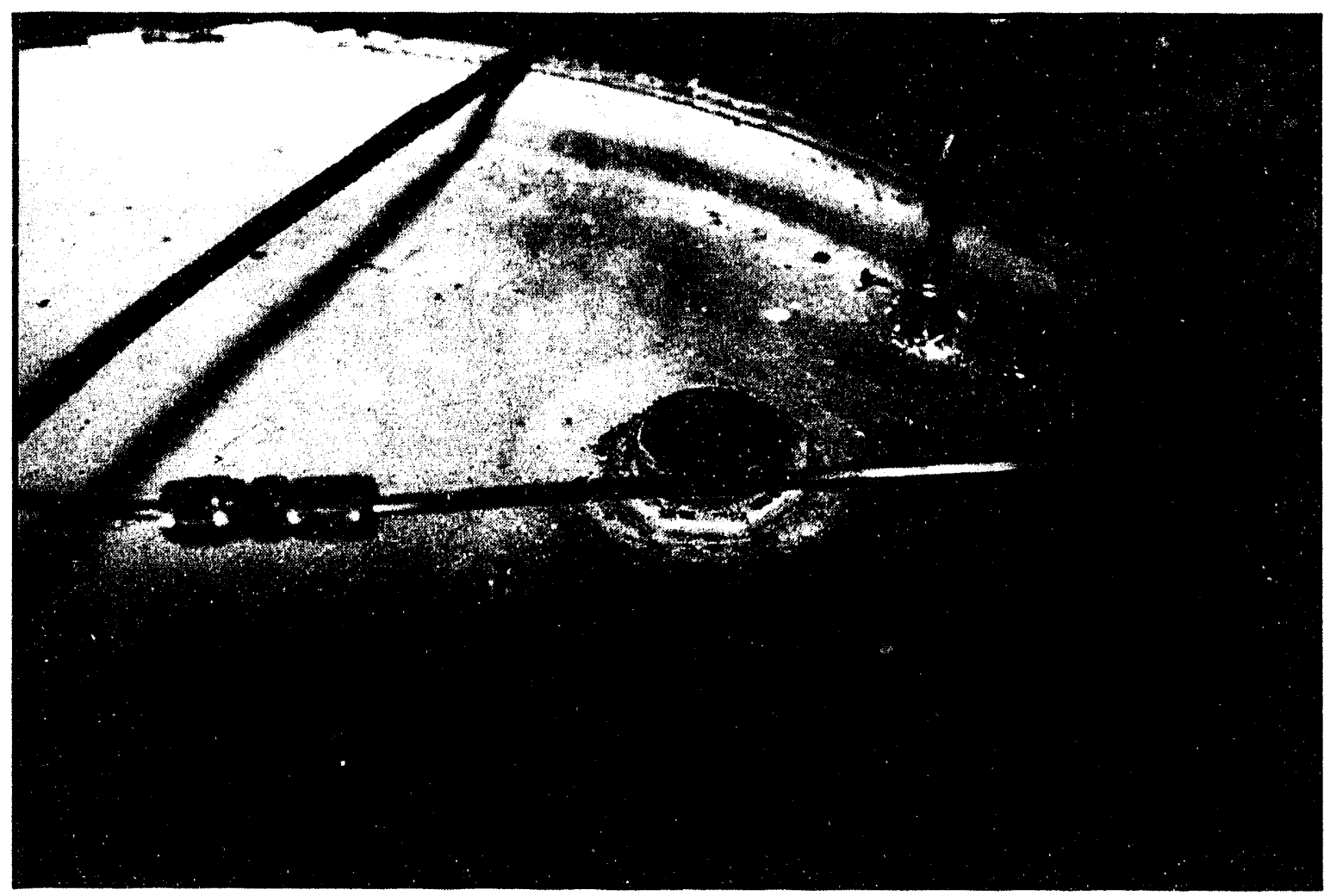

Photo 22: Opened bung hole after plastic plug melted and blew out during test WDPAN2. 


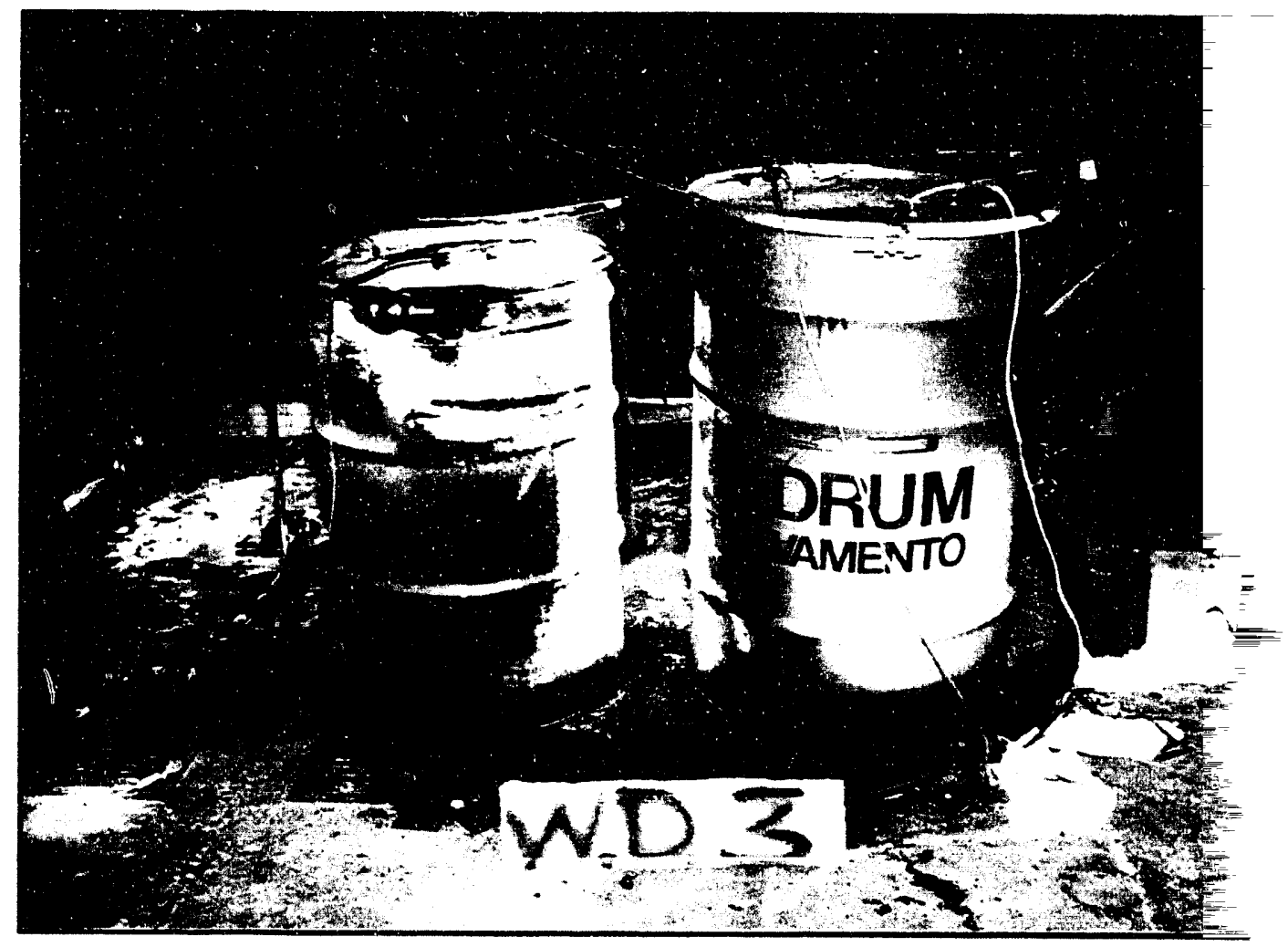

Photo 23: Post test condition of the drums used in WDPAN3.

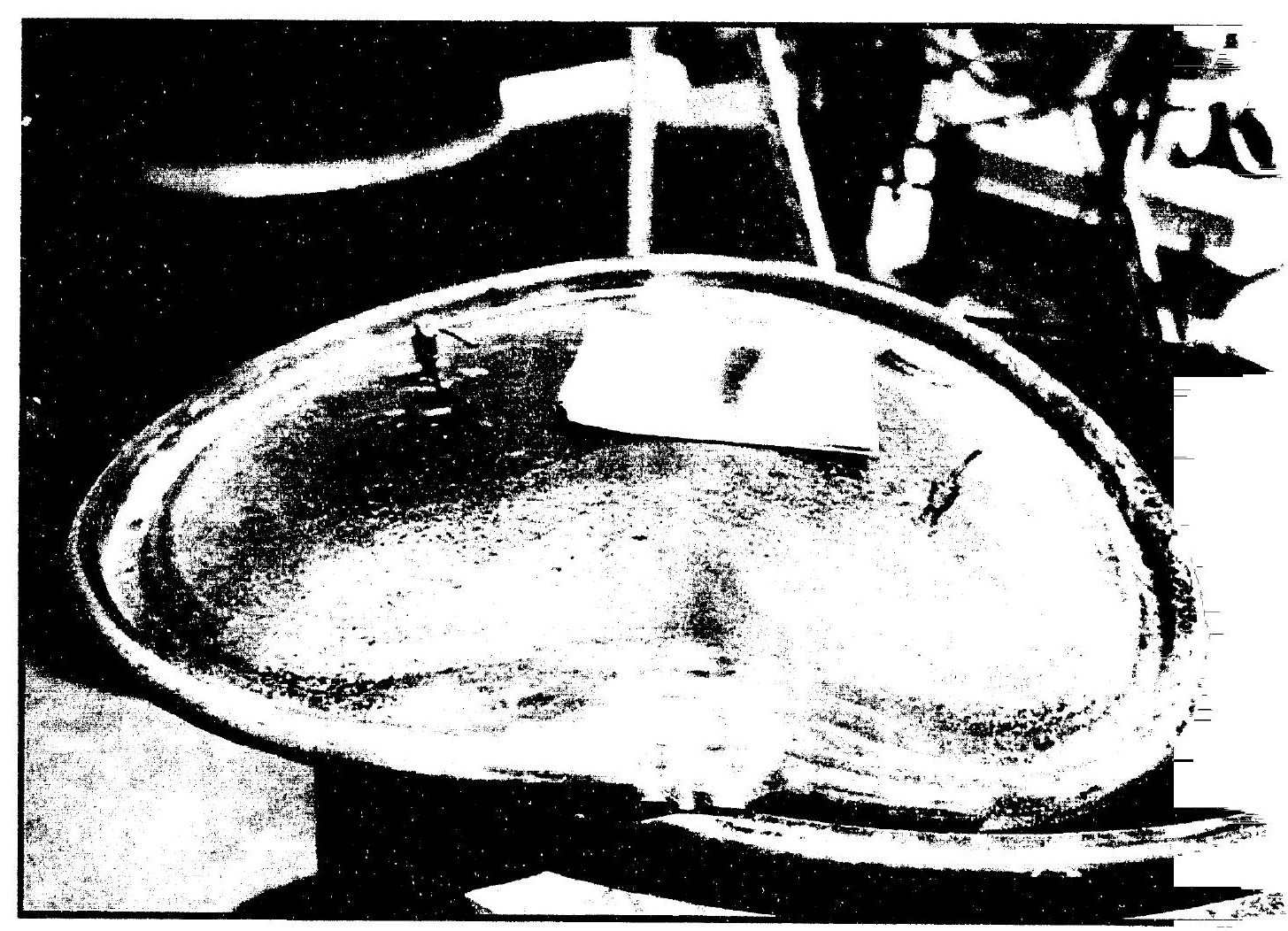

Photo 24: Post test condition of lid that blew off of drum 1 in test WDPA 


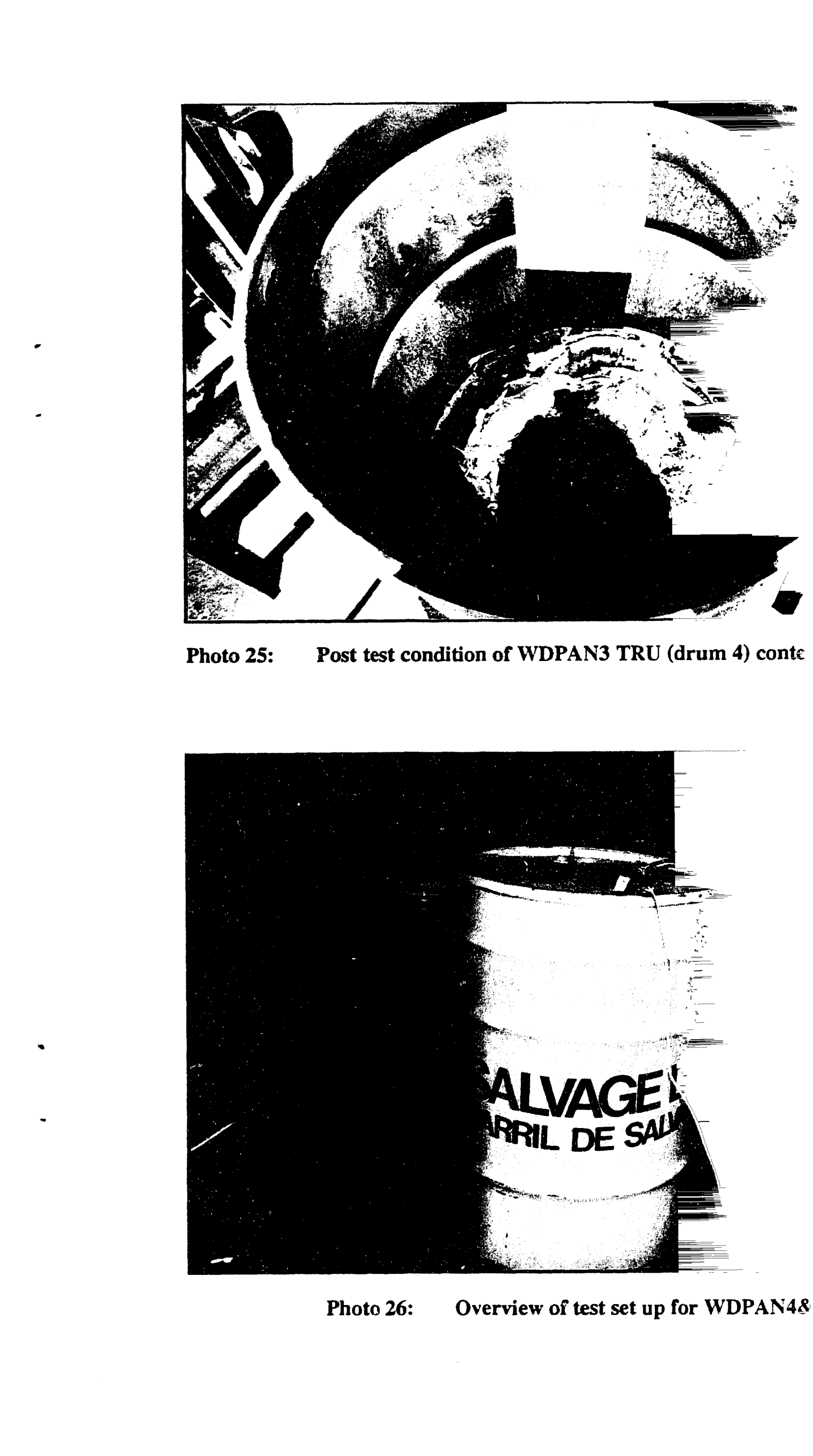



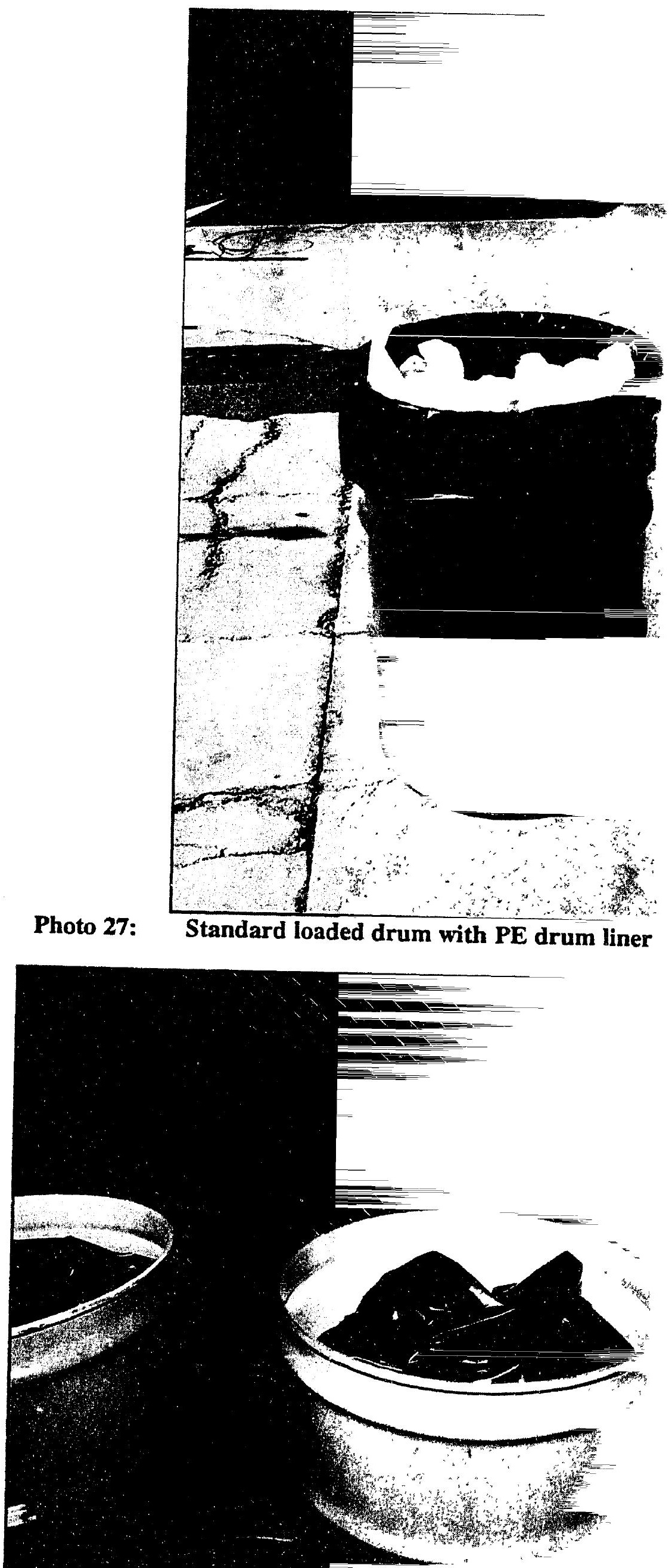

Photo 28: Typical folding in of drum liner before 


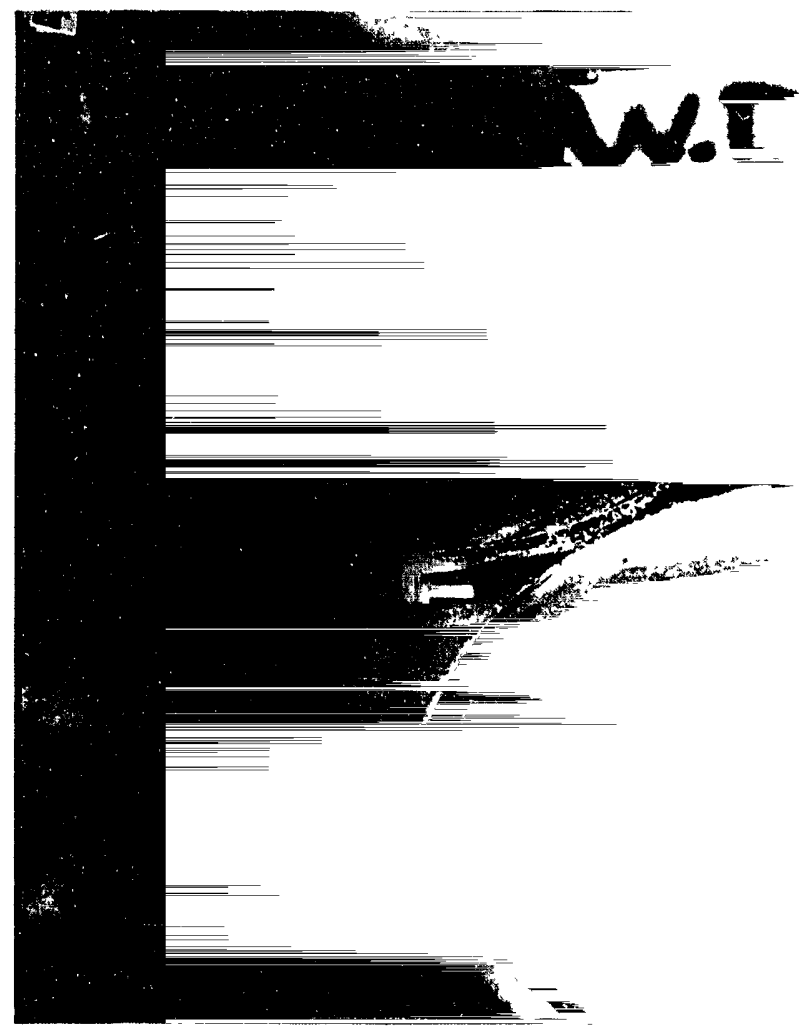

Photo 29: Post test condition o

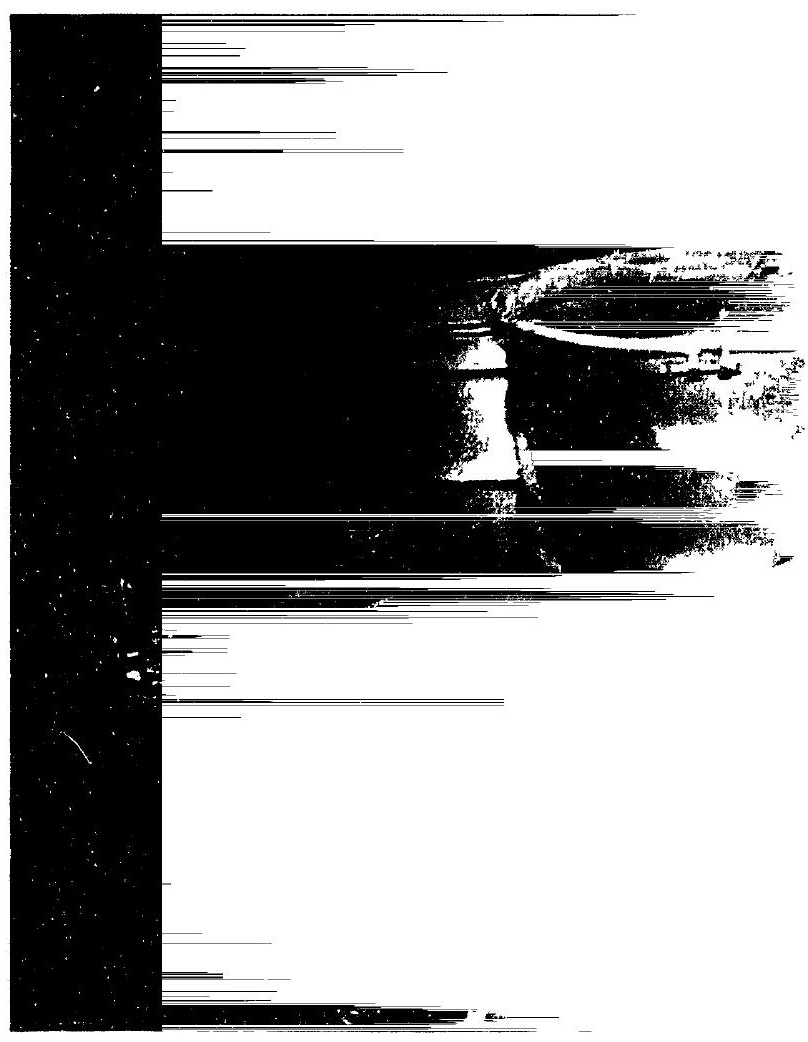

Photo 30: Post test condition o 


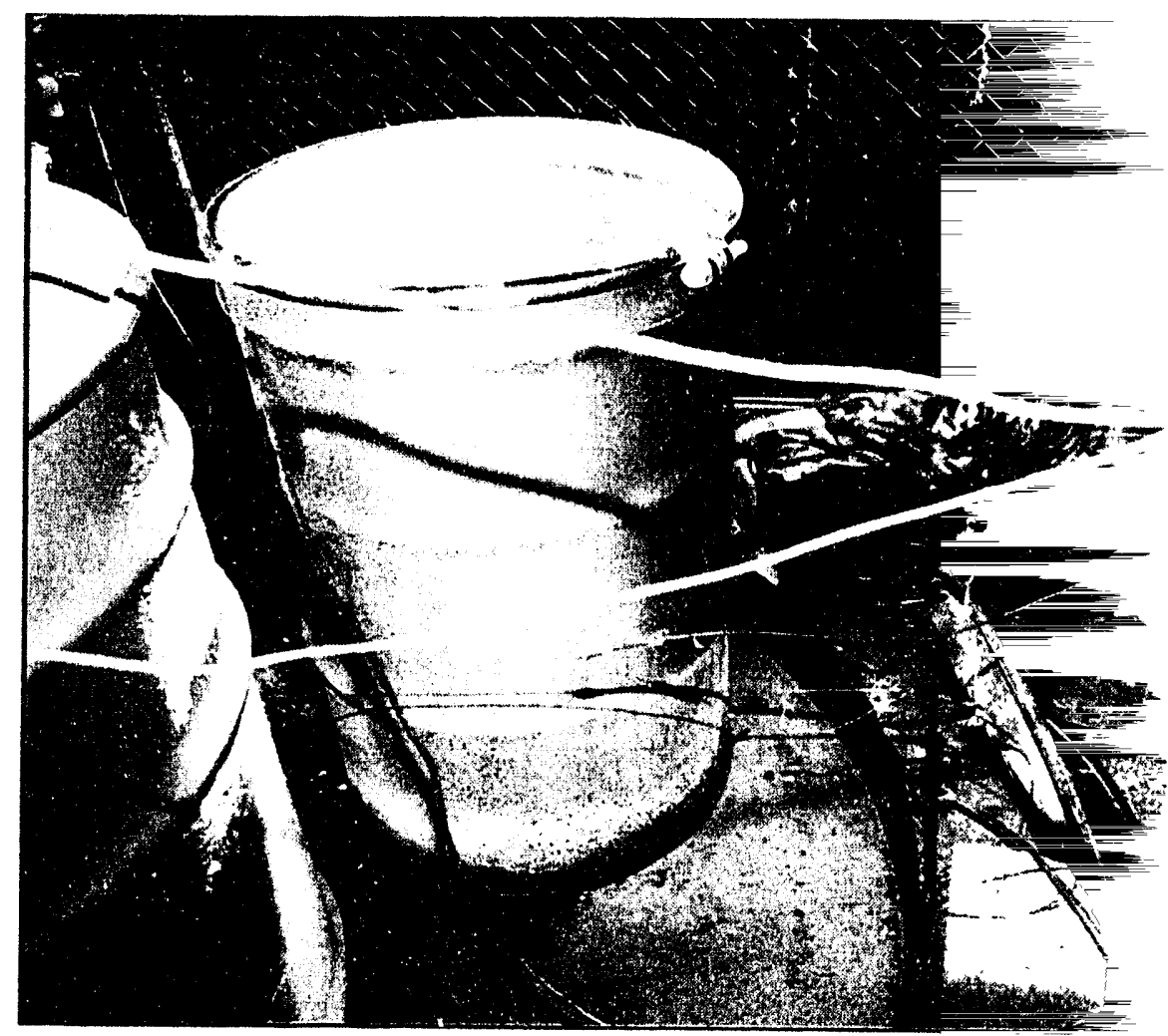

Photo 31: Location and condition of the lid that blew off of $\mathrm{dr}$

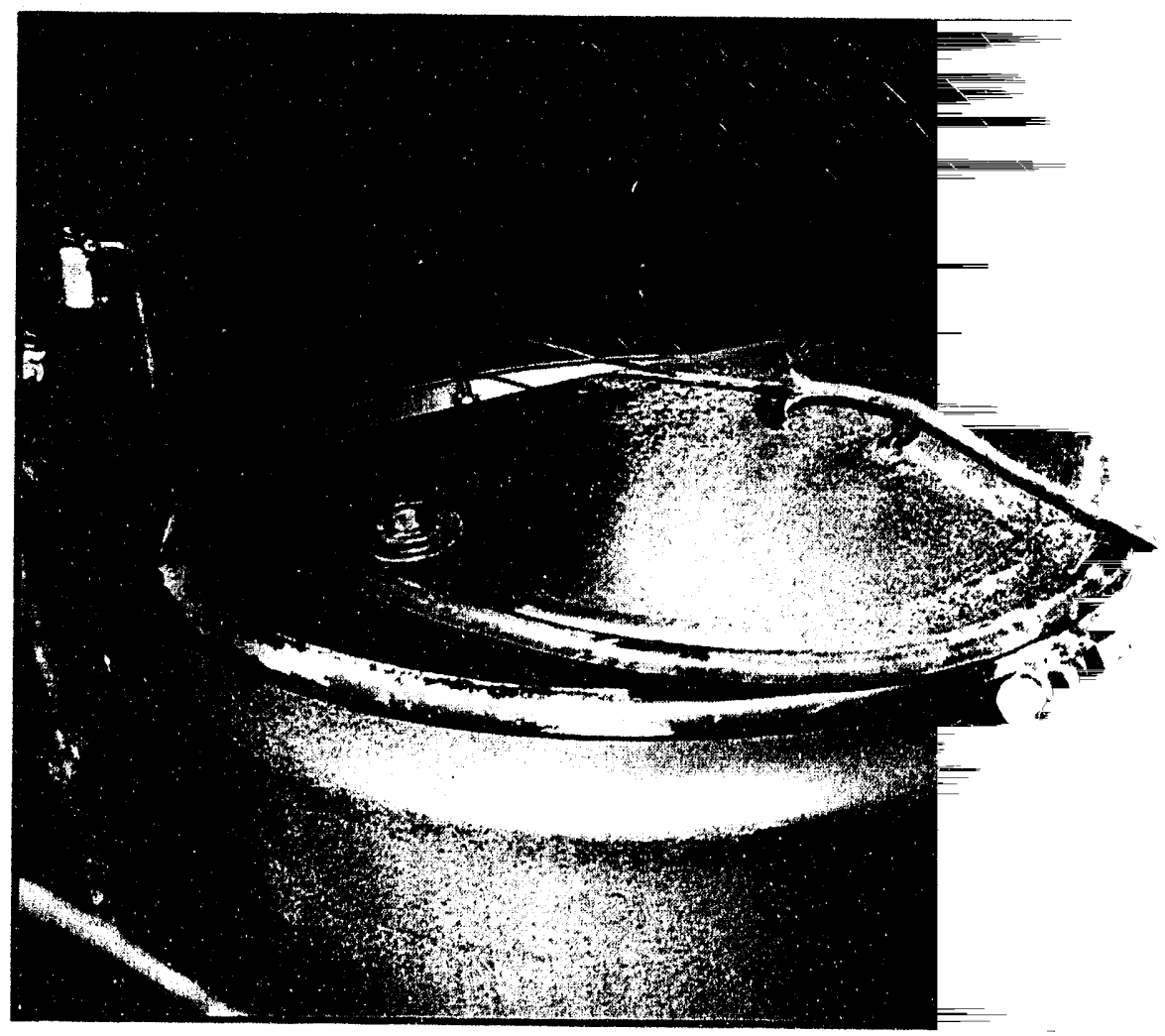

Photo 32: Lid from drum 2, of test WDPAN5, after it was place 


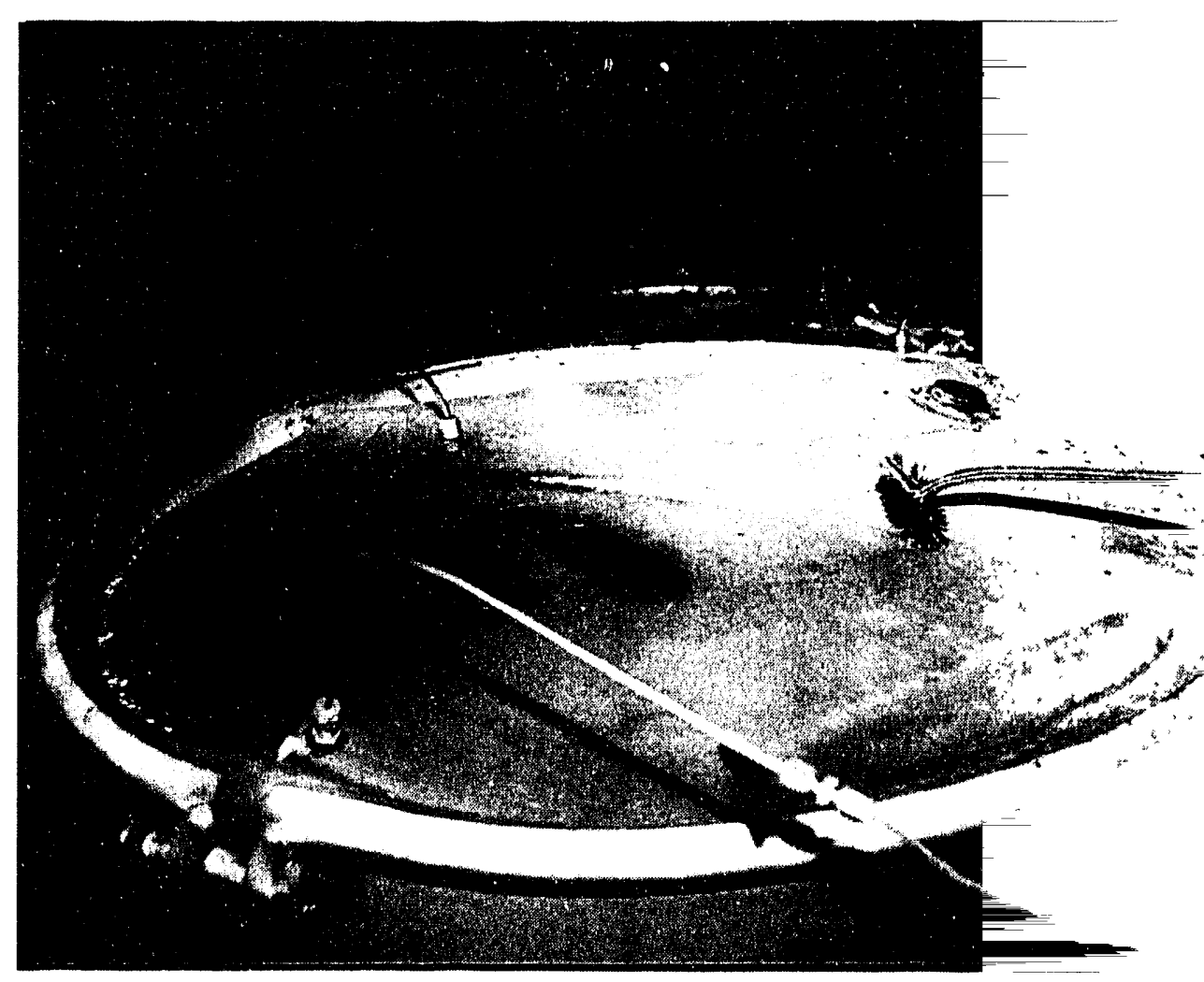

Photo 33: Bulge in the top of the salvage drum tested WD:

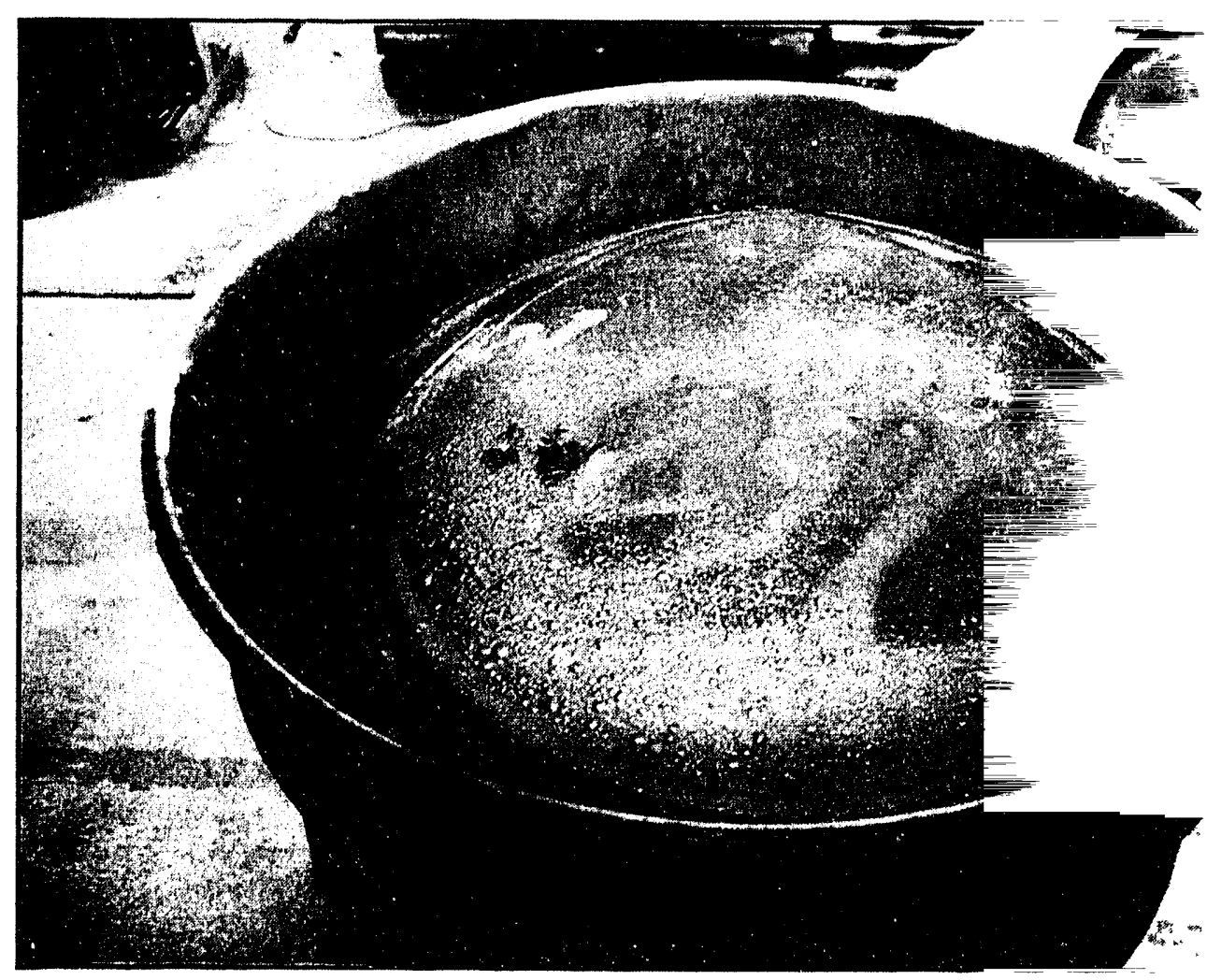

Photo 34; Bulge in the top of the inner drum tested WDP 


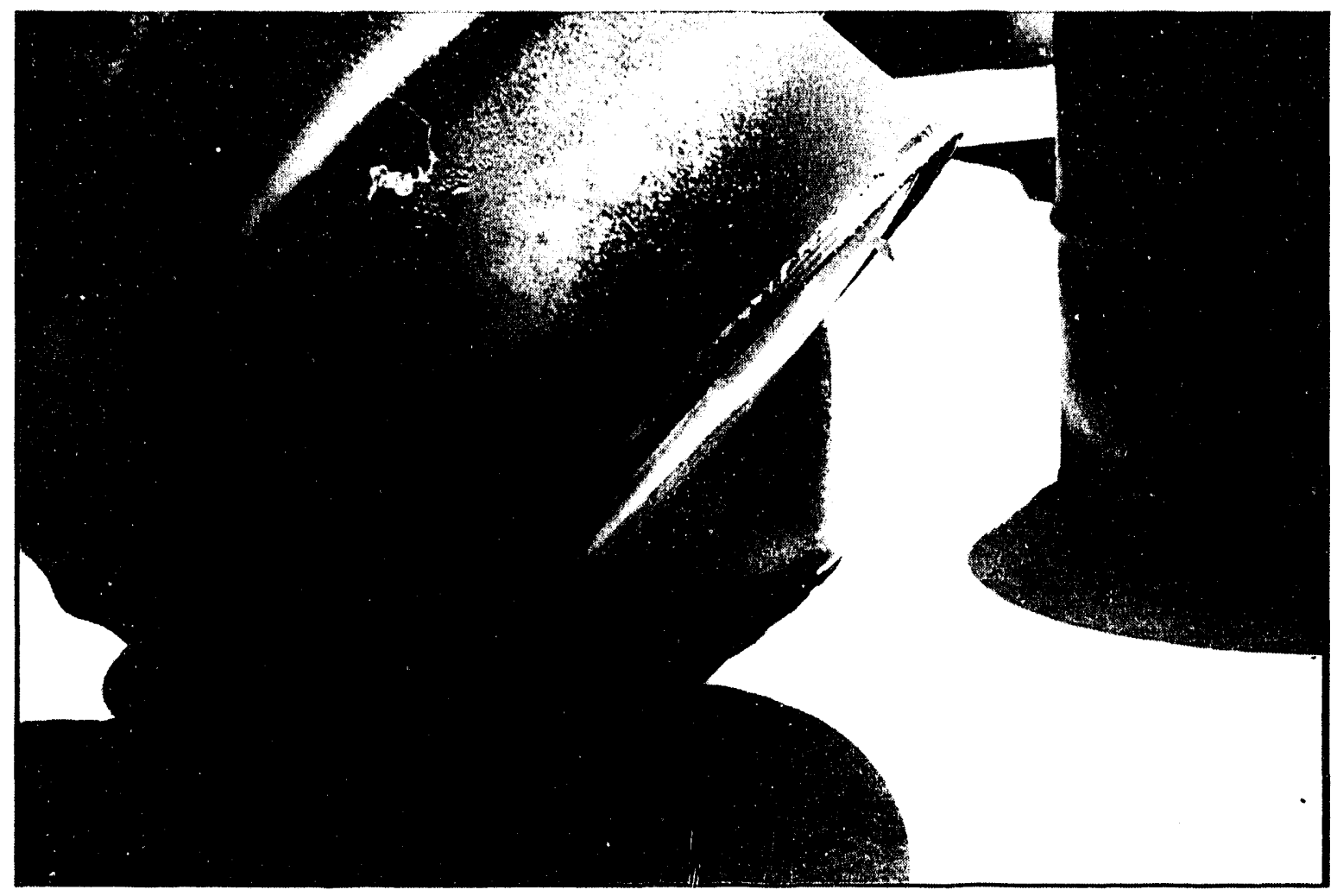

Photo 35: Bulge in the bottom of the salvage drum tested WDPAN5. 
ATTACHMENT 1 
Date: 7 Jun 19

FILENAME CHANNEL LOCATION

WDPAN 1

- WDPAN I

$\times$ WDPAN 1

- WDPAN1

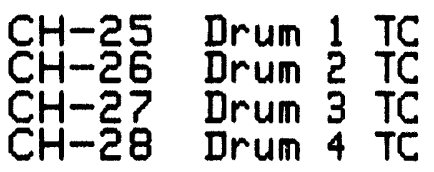

Time: 10:02:43 UNIT OF MEASURE SCALE

Degrees Celsius 1000 Degrees Celsius 1000 Degrees Celsius 1000 Degrees Celsius 1000

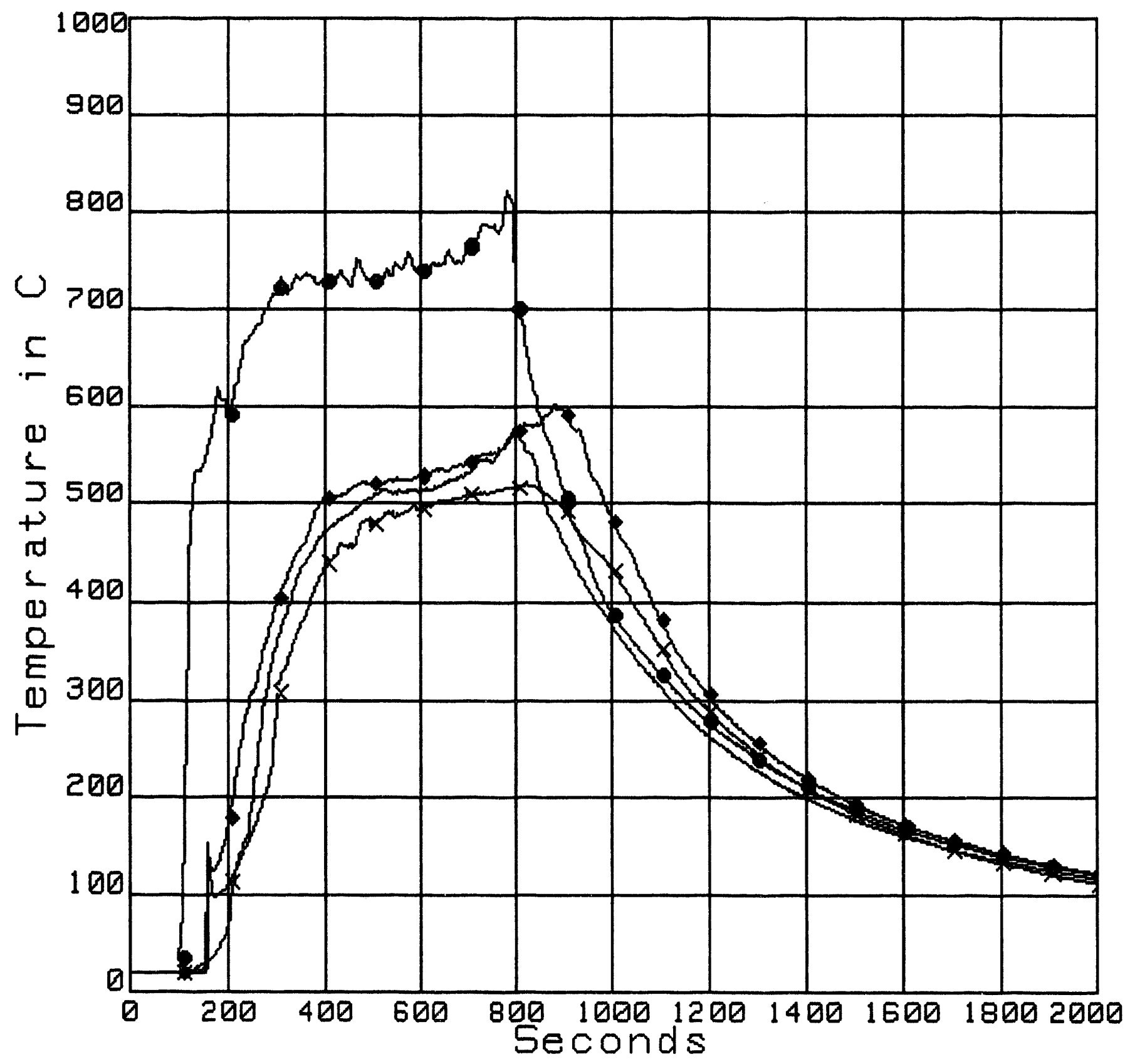


Date: 7 Jun 19

Time: 10:02:43

FILENAME CHANNEL LOCATION UNIT OF MERSURE SCRLE WDPRN 1 - WDPAN 1

$\times$ WDPAN 1

- WDPANI

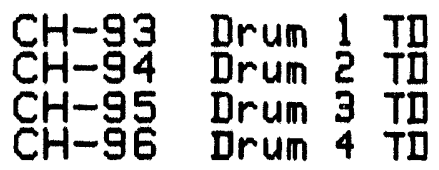

PSI

PSI

P5I

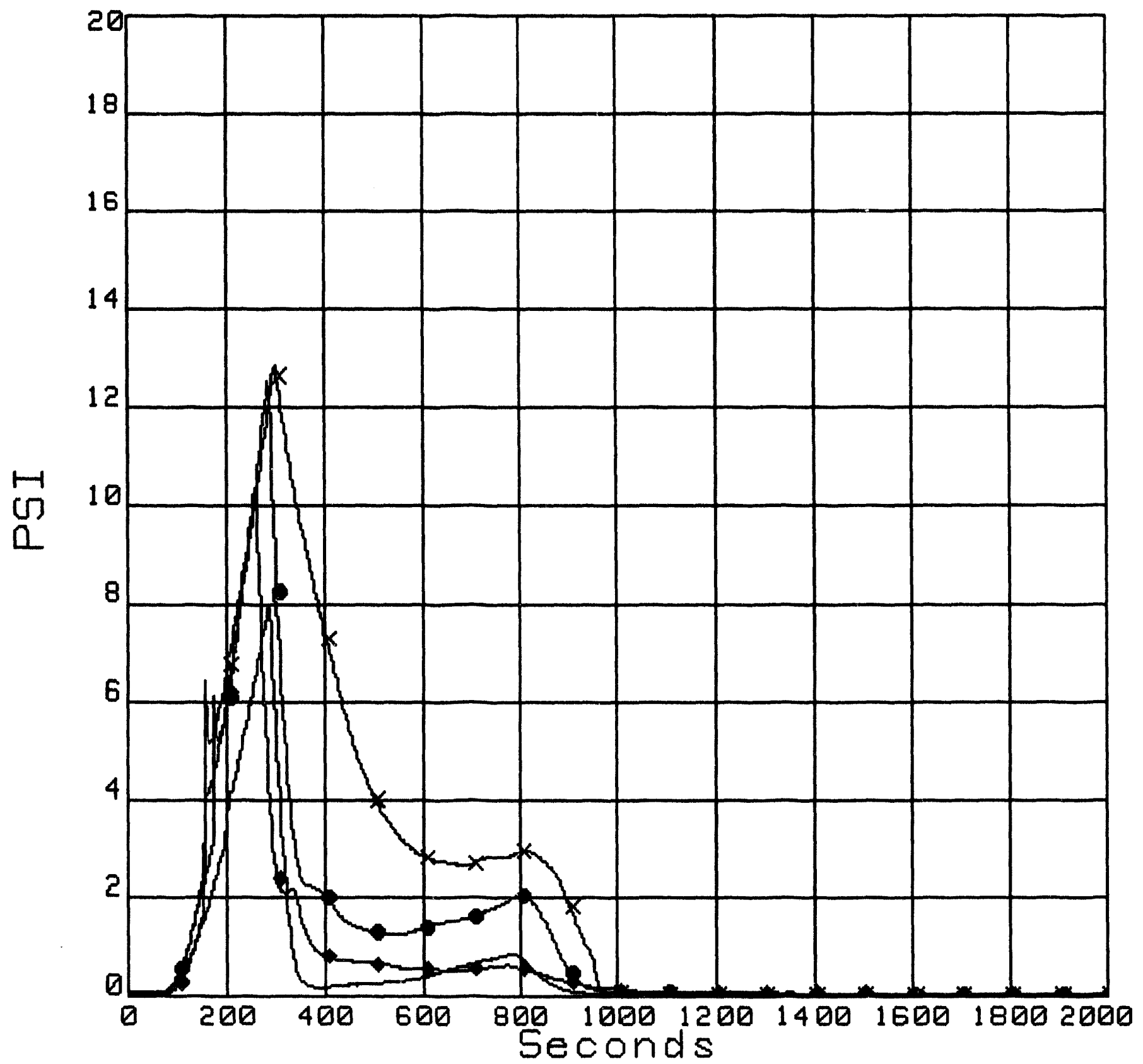


Date: 7 Jun 19

FILENAME CHANNEL LOCATION

WDPAN 1

- WDPANI
$\begin{array}{ll}\mathrm{CH} \\ \mathrm{CH}-25 & \text { Drum } 1 \text { TC } \\ \mathrm{Crum} & \mathrm{T}\end{array}$
Time: 10:02:43 UNIT OF MEASURE SCRLE Degrees Celsius 1000

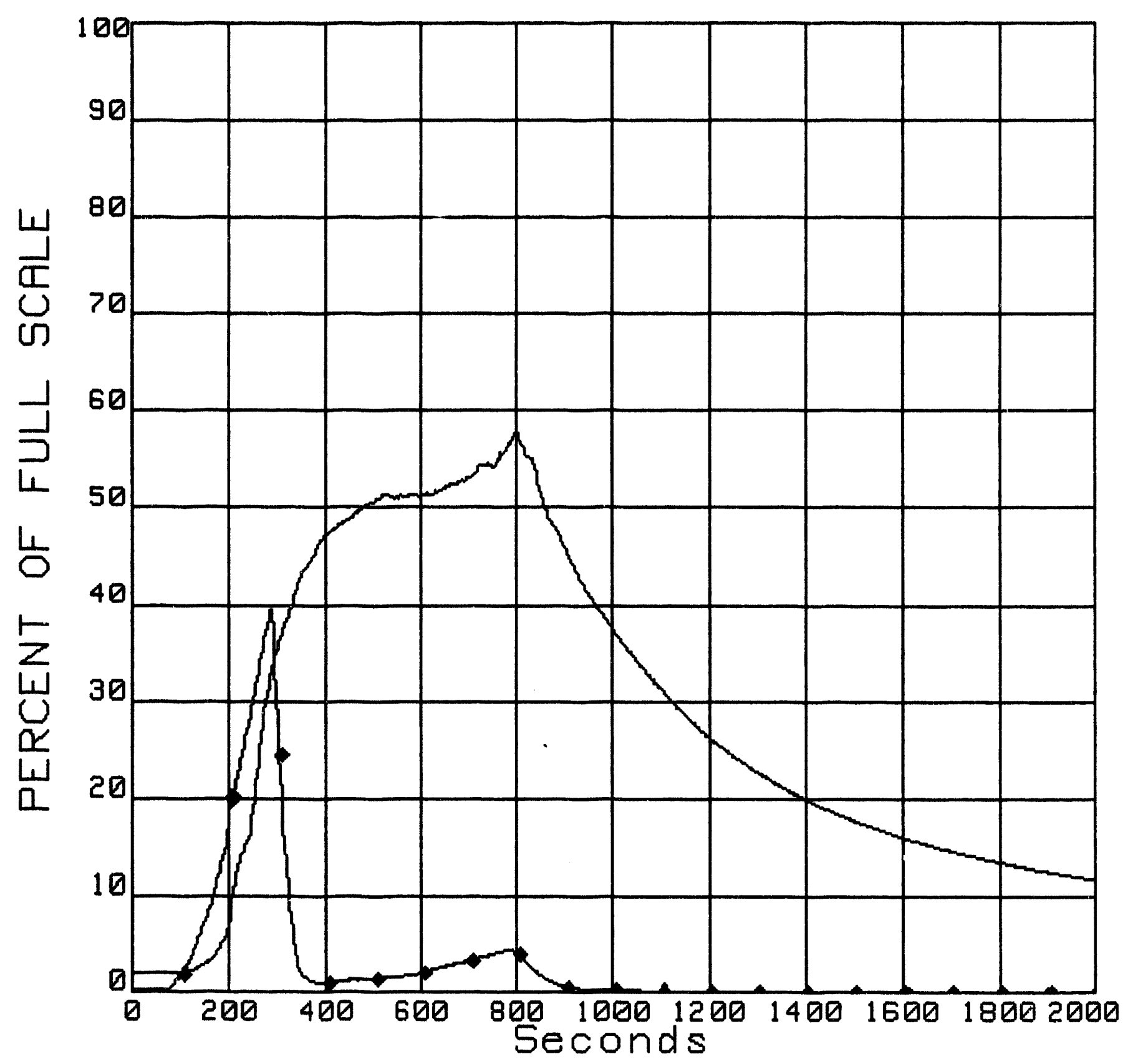


Date: 7 Jun 19

FILENAME CHANNEL LOCATION

WDPAN 1

- WDPAN 1

Time: 10:02:43 UNIT OF MEASURE SCALE Degrees Celsius 1000 PSI

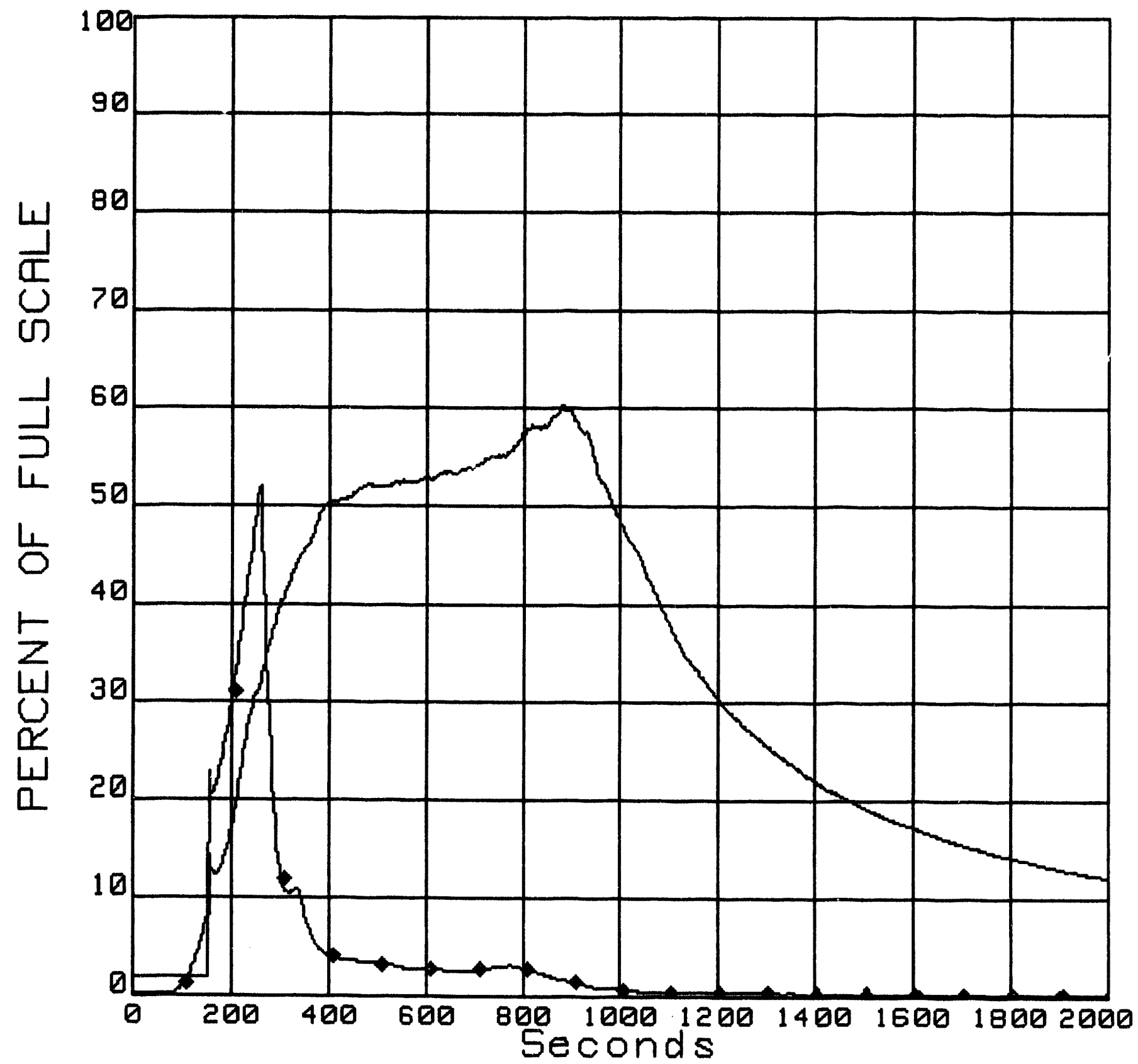


Date: 7 Jun 19

Time: 10:02:43

FILENAME CHANNEL LOCATION UNIT OF MEASURE SCALE WDPAN 1

- WDPAN!

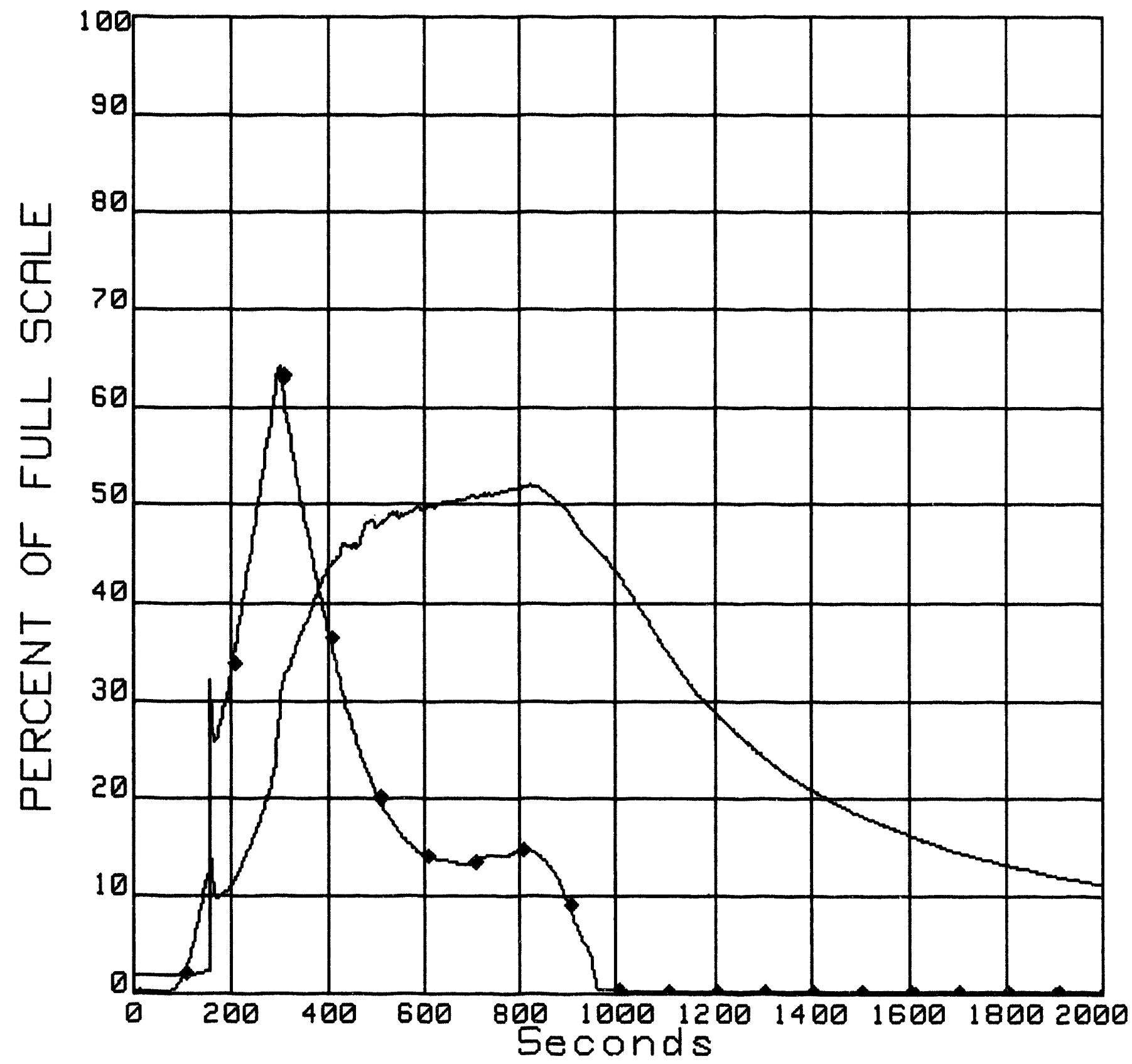


Date: 7 Jun 19

FILENAME CHANNEL LOCATION

WDPRN 1

- WDPRN 1
Time: 10:02:43 UNIT OF MEASURE SCALE Degrees Celsius $\quad 1000$

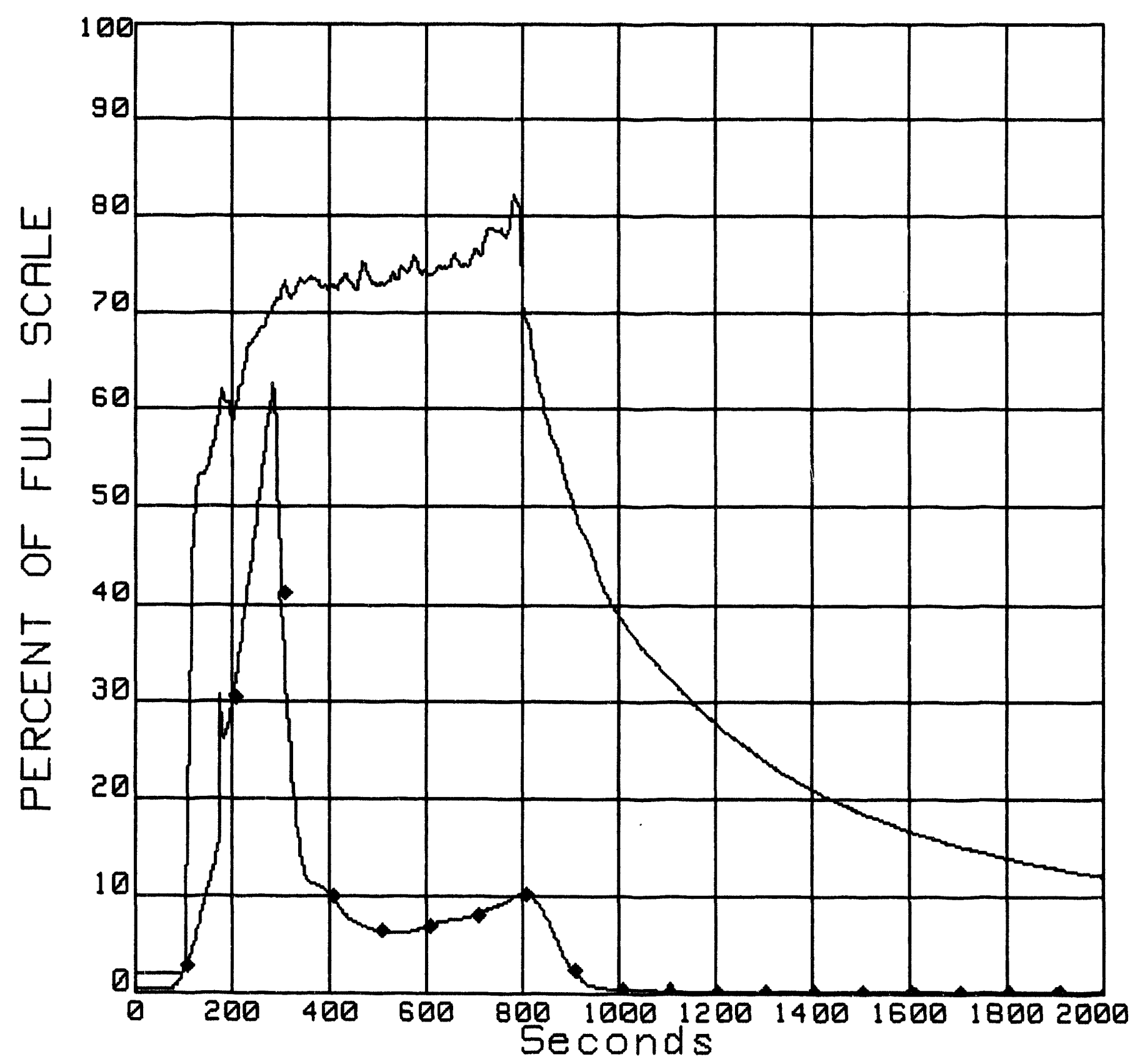


Date: 7 Jun 19

CH-2̇ Ambient Rir

\section{WDPAN 1}

Degrees Celsius : 10:02:43

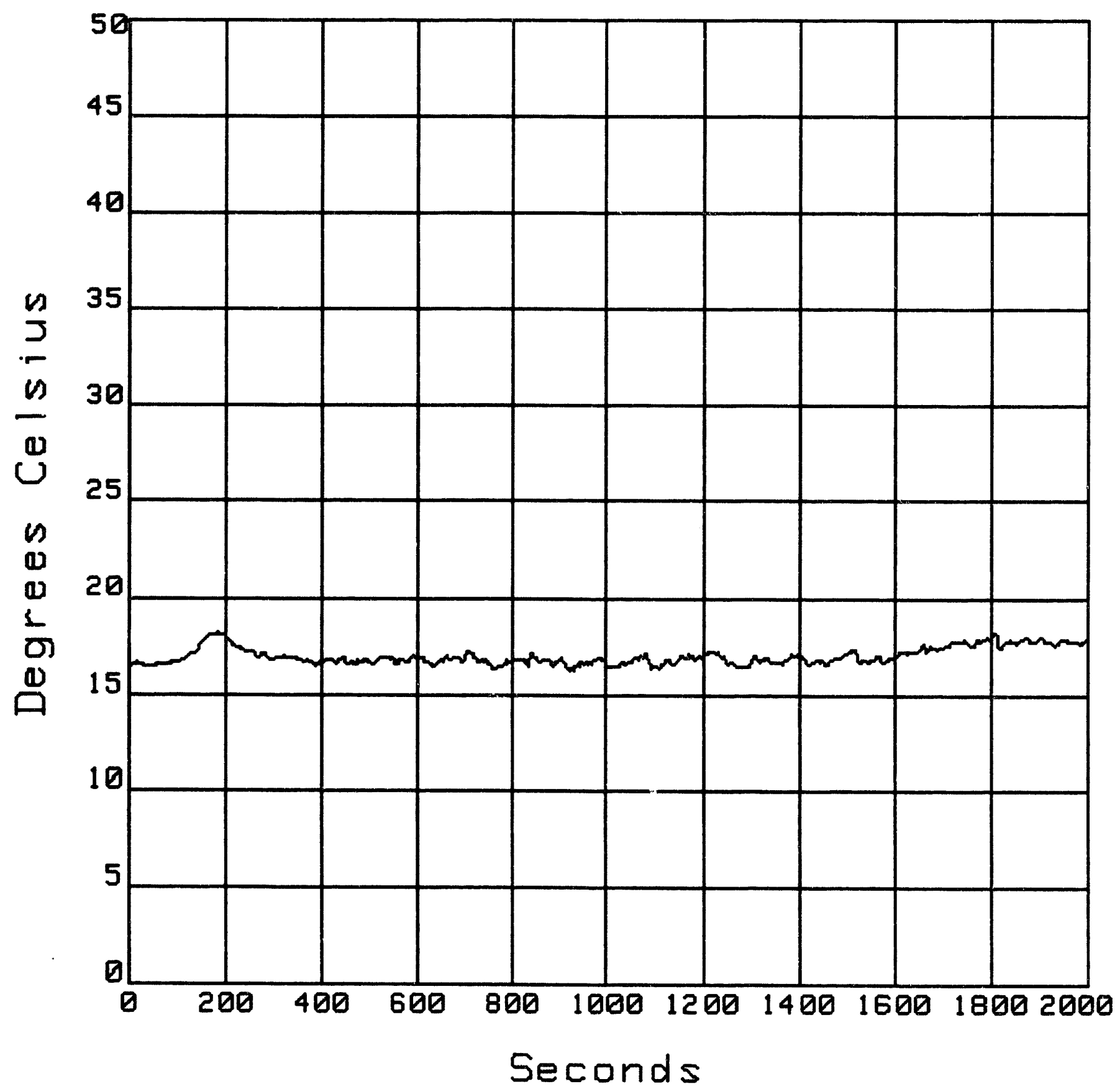

No. of channels $=27$ 
Ratei Z Jun 19

WDPAN 1

Degrees Celsius : 10:02:43

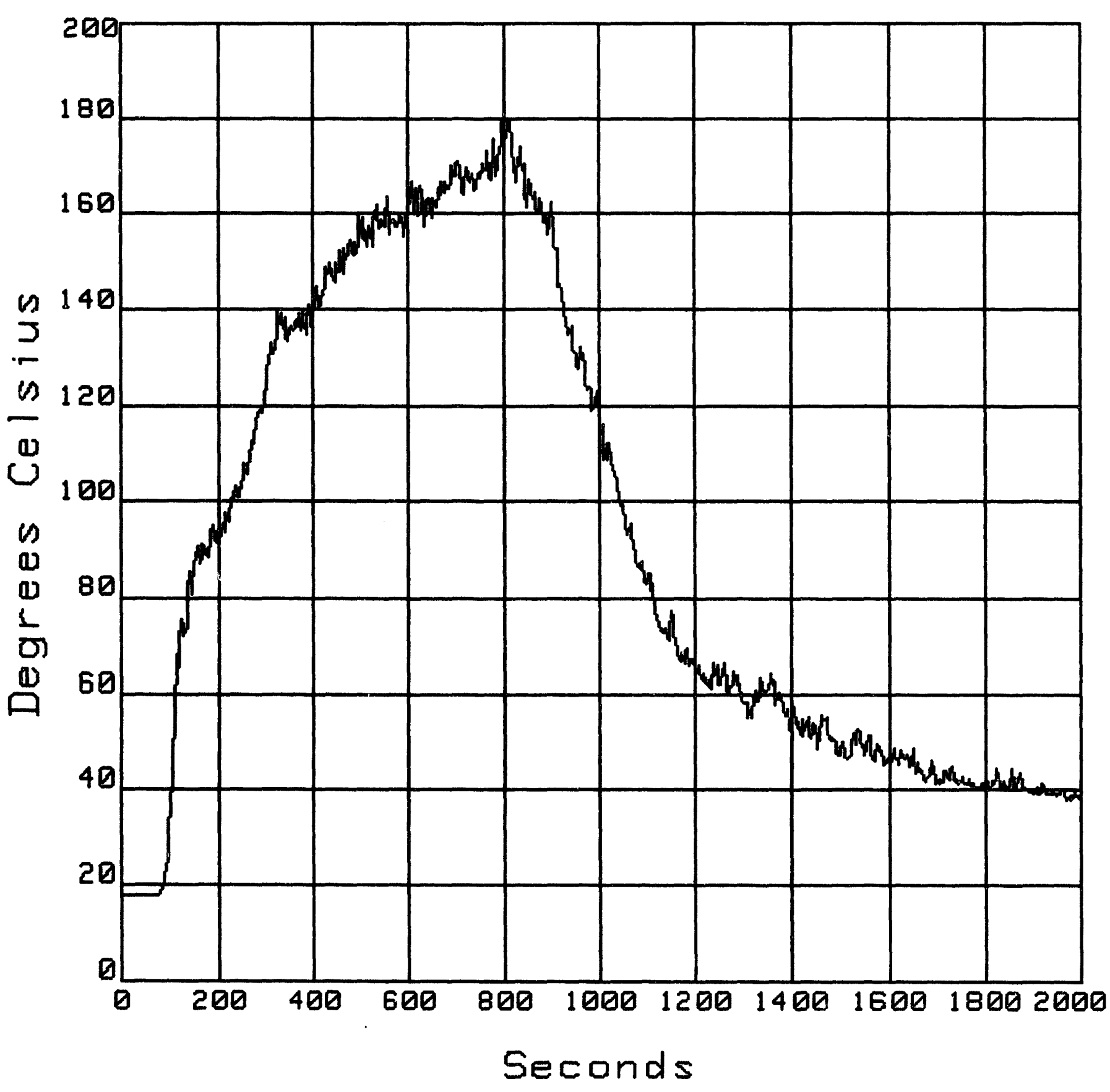

No. of channels $=27$ 
Date: 7 Jun 19

WDPAN 1

Degrees Celsime: 10:02:43

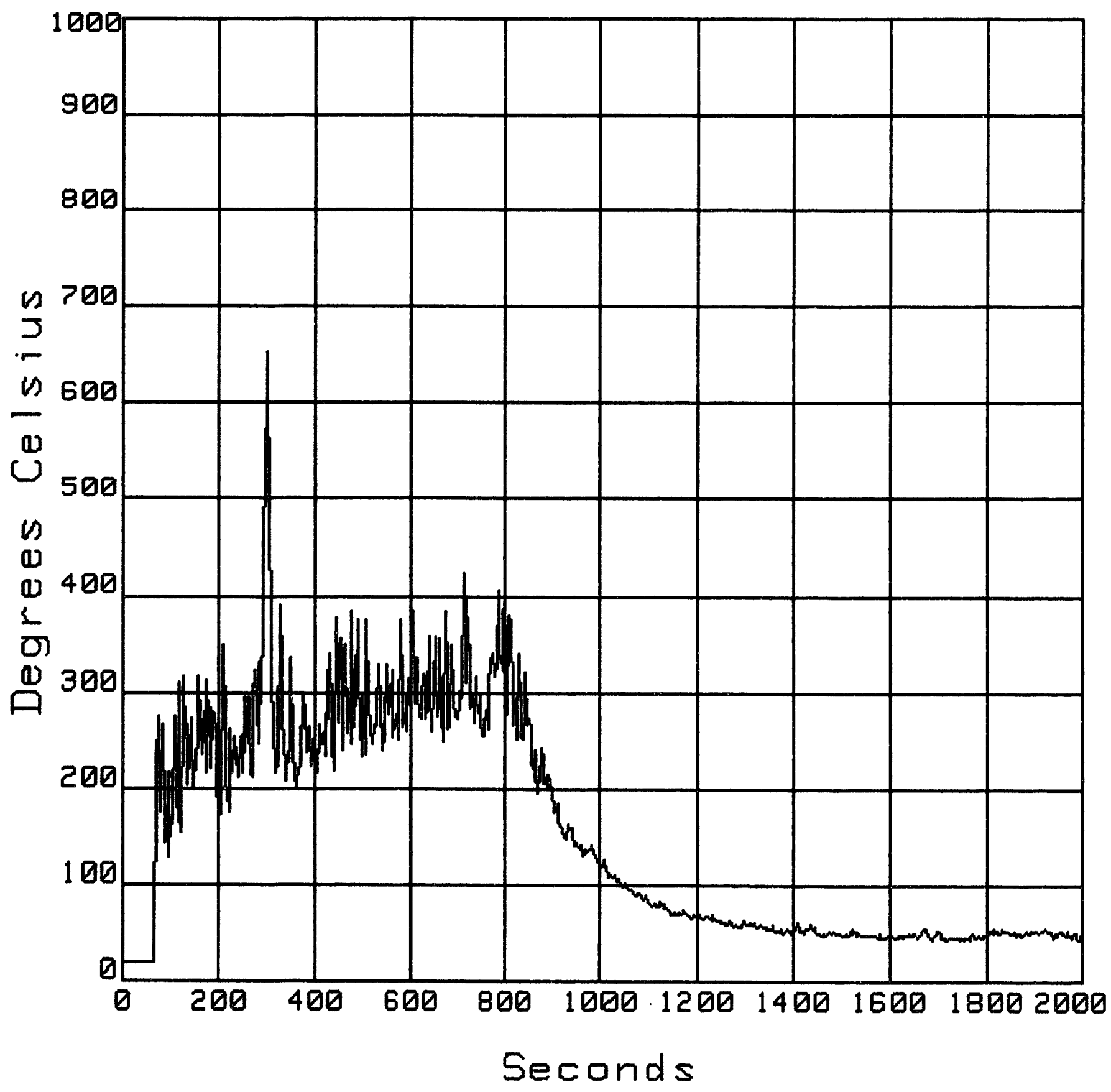

No. of channels $=27$ 
Date: 7 Jun 19

WDPAN 1

Degrees Celsime: 10:02:43

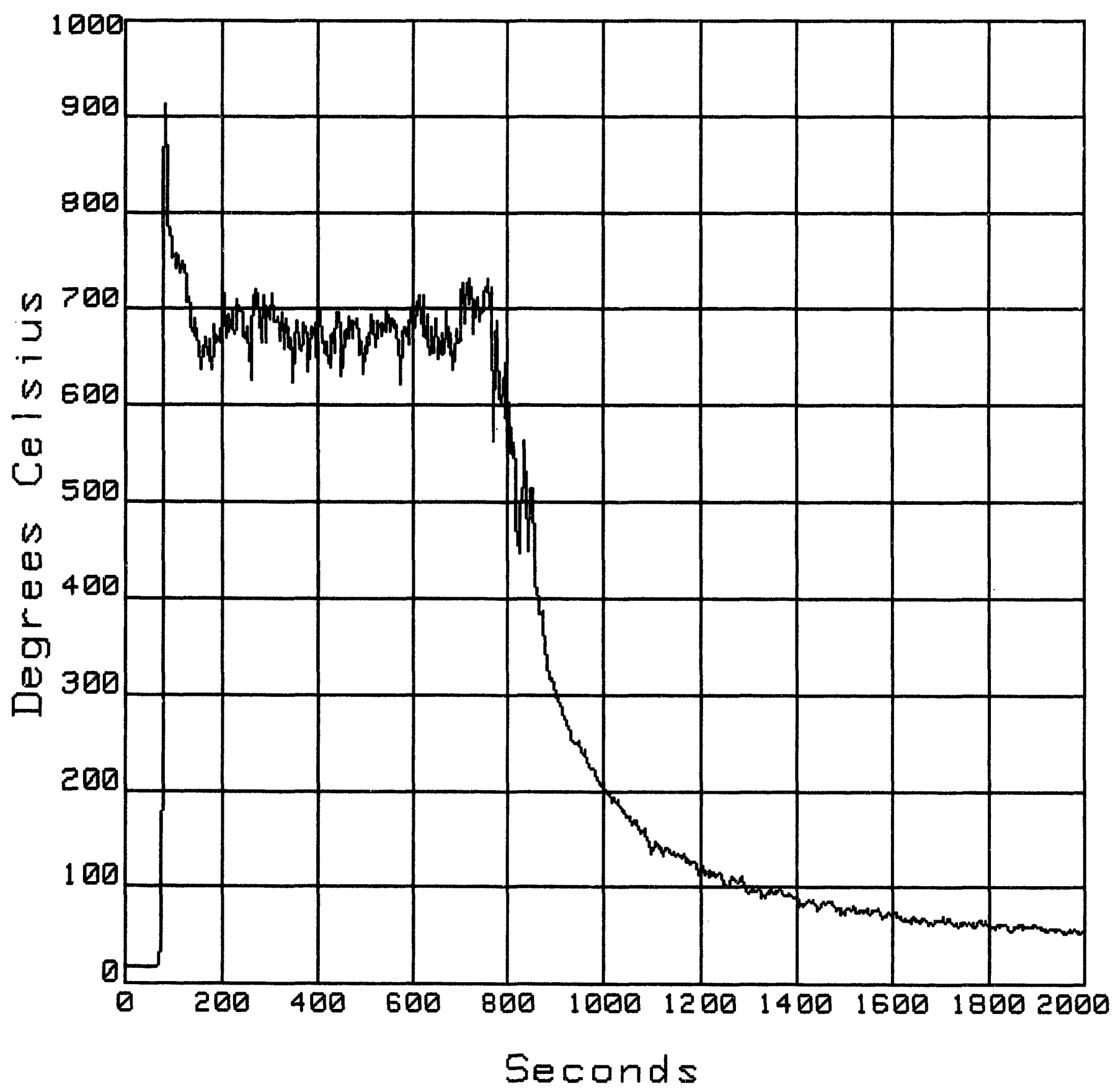

No. of channels $=27$ 
Date: $\mathrm{P}$ Jun 19

WDPAN 1

Degrees Celsius : 10:02:43

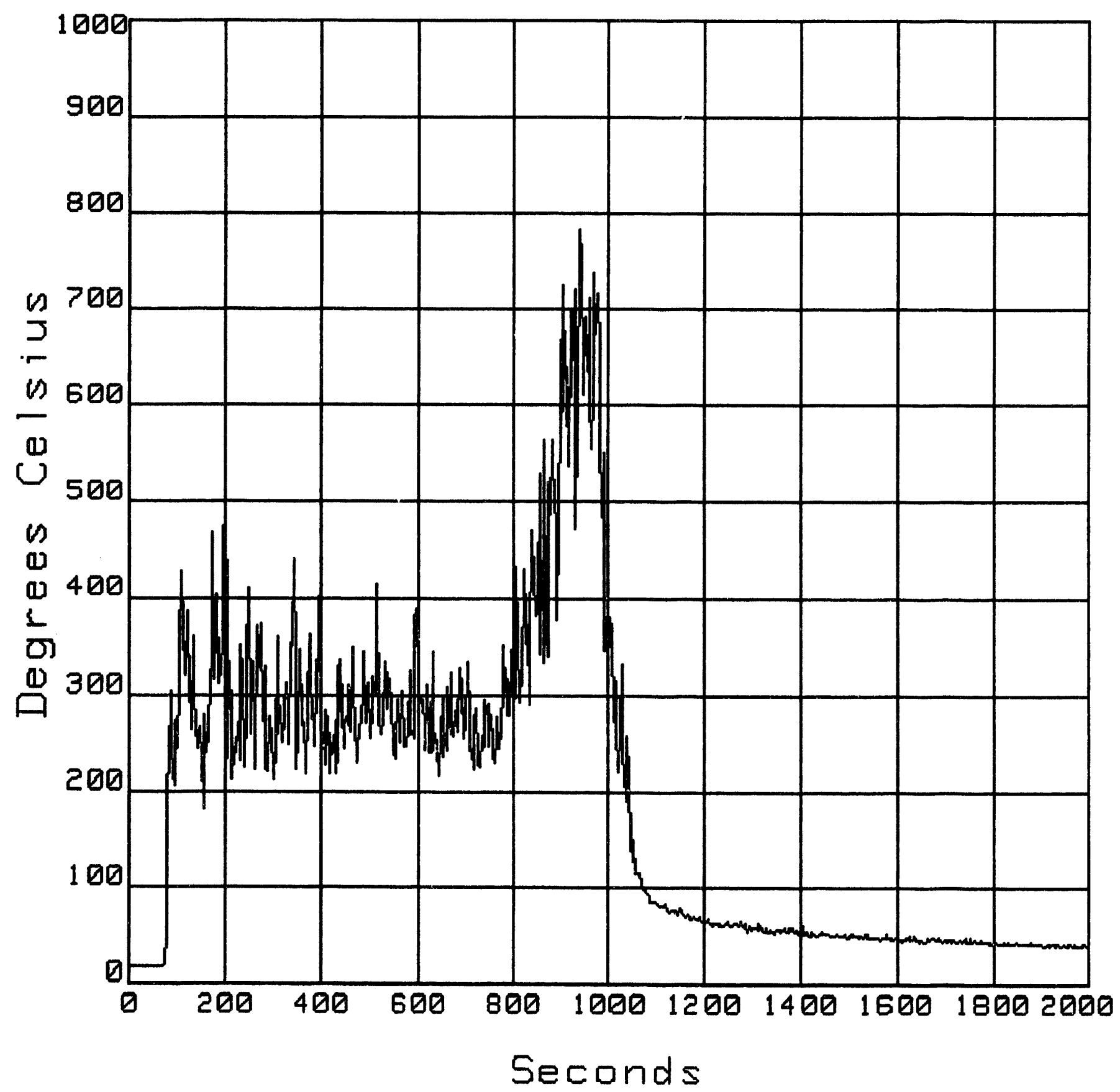

No. of channels $=27$ 
Date: $\underset{\text { Drum } 19}{\text { Jun }}$

WDPAN 1

Degrees Celsime: 10:02:43

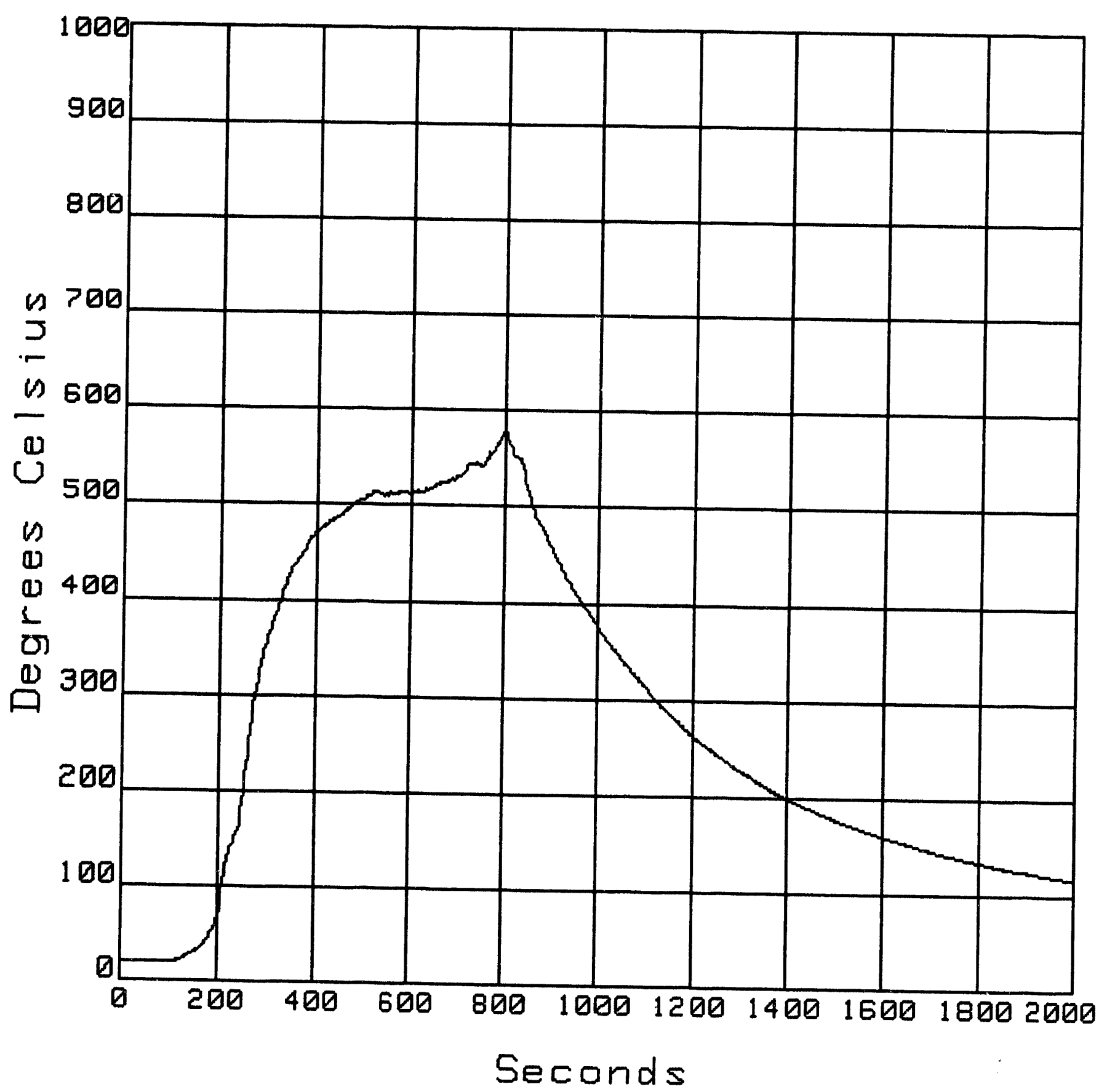

No. of channels $=27$ 
Date: $\operatorname{DJun}_{\text {Drum }} 2^{19} \mathrm{TC}$

WDPRN 1

Degrees Celsime $\begin{aligned} & \text { Time: } 02: 43 \\ & 1000\end{aligned}$

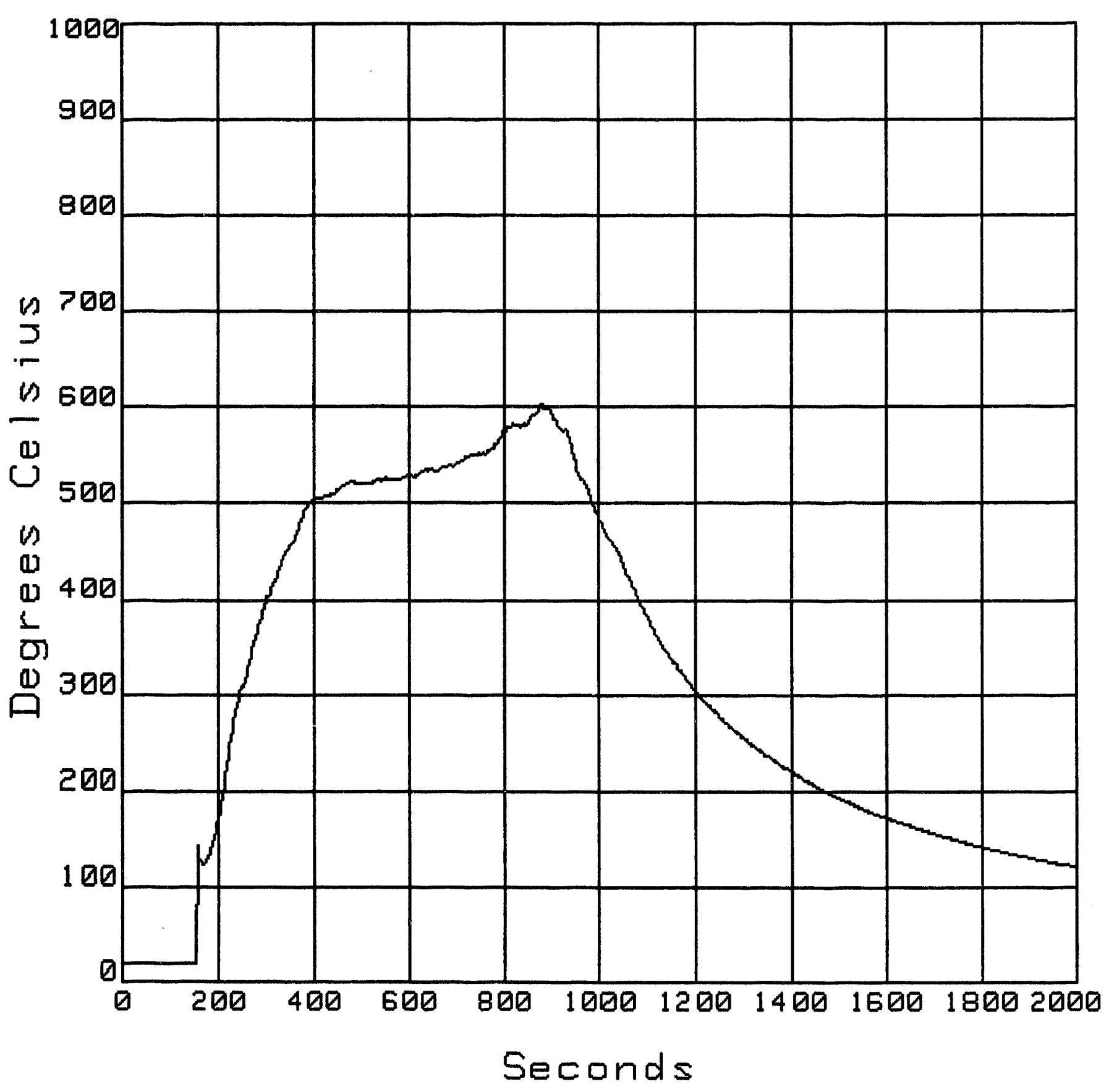

No. of channels $=27$ 
Date: $\quad$ Jun 19

WDPAN 1

Degrees Celsime: $10: 02: 43$

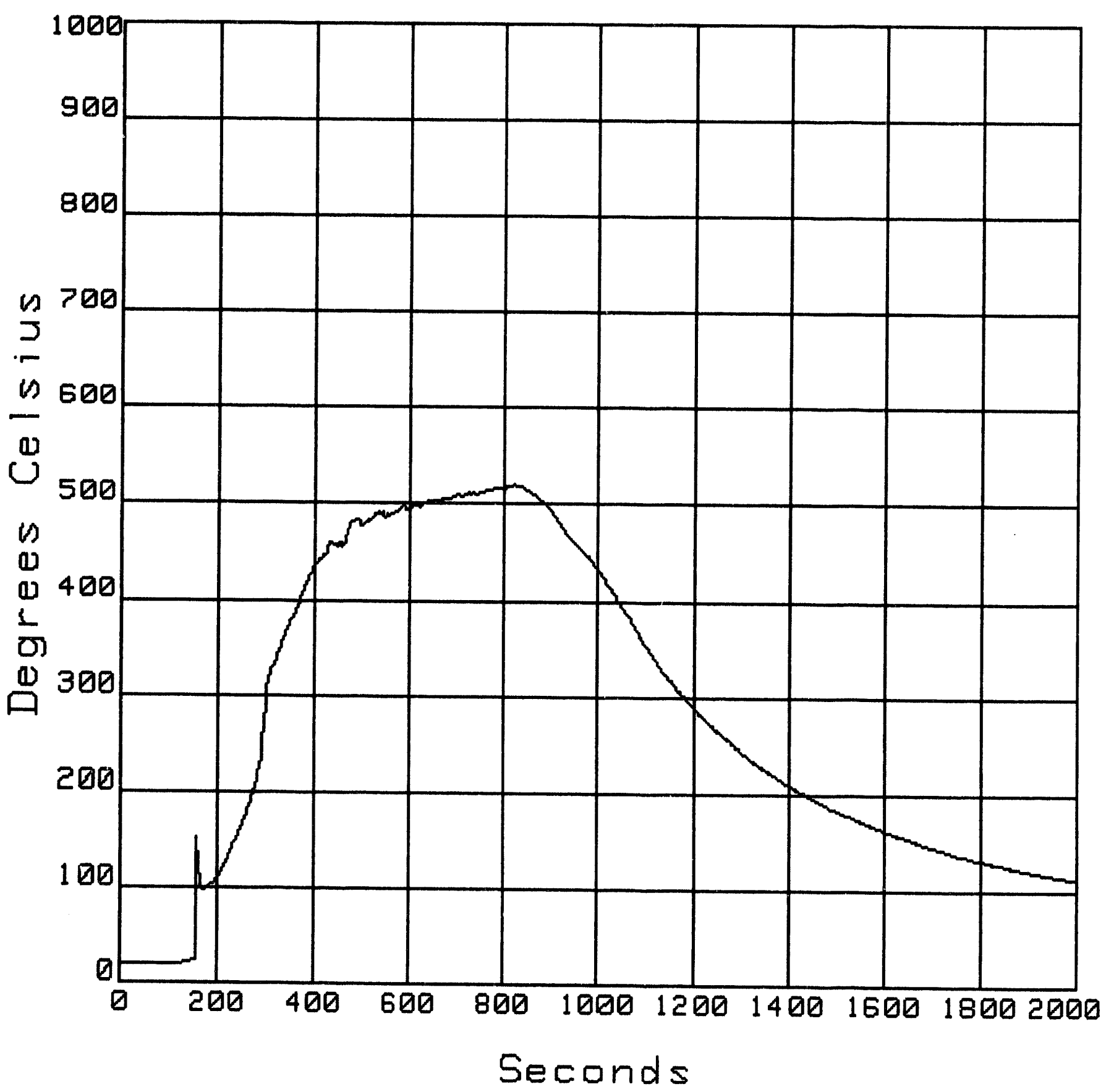

No. of channels $=27$ 
Date: $\quad$ T Jun 19

WDPAN 1

Time: 10:02:43

Degrees Celsius

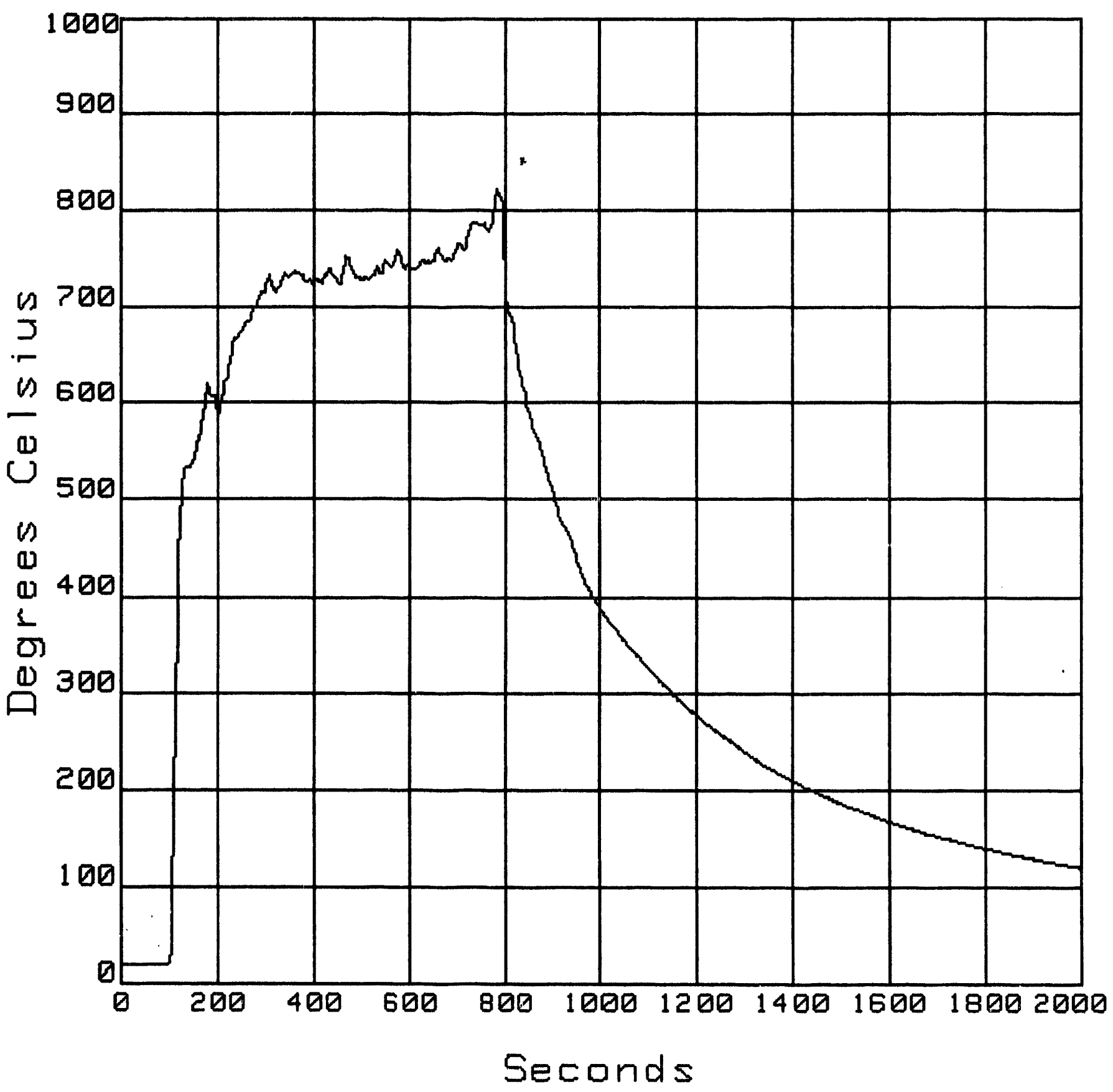

No. of channels $=27$ 


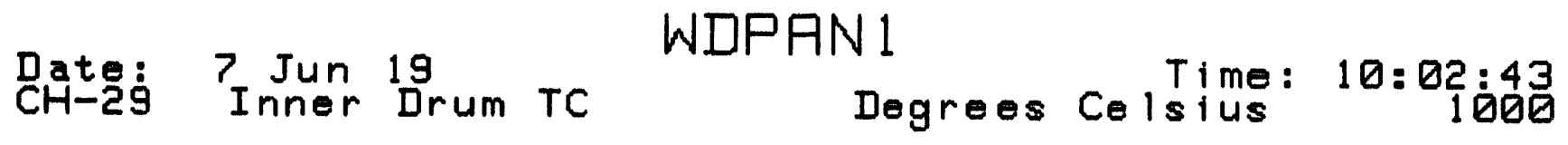

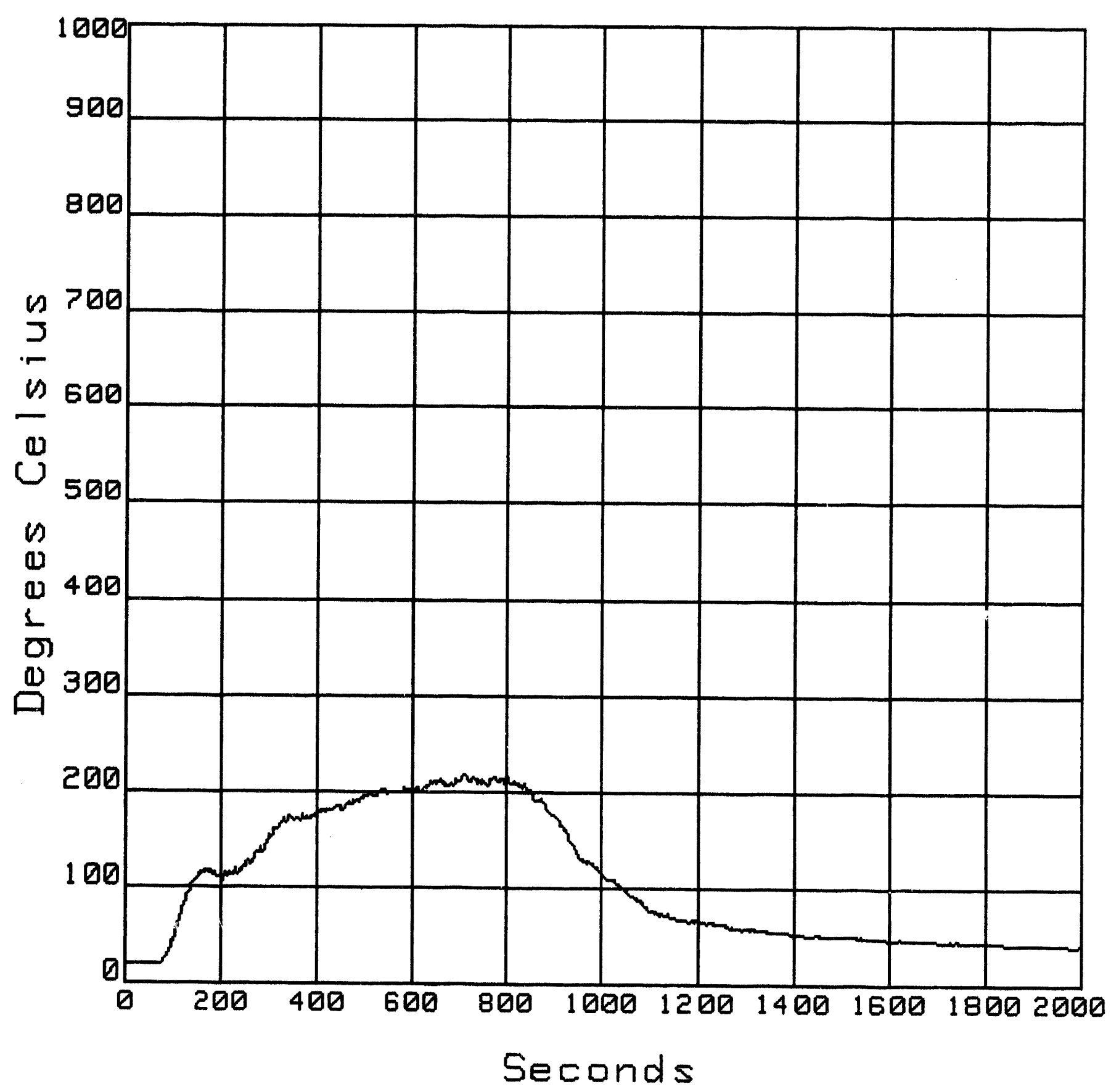

No. of channels $=27$ 
Date: ? Jun 19 TH

WDPAN 1

CH-80 O2 ERST END $\% 02$

Time: 10:02: 23

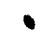

$\rightarrow$

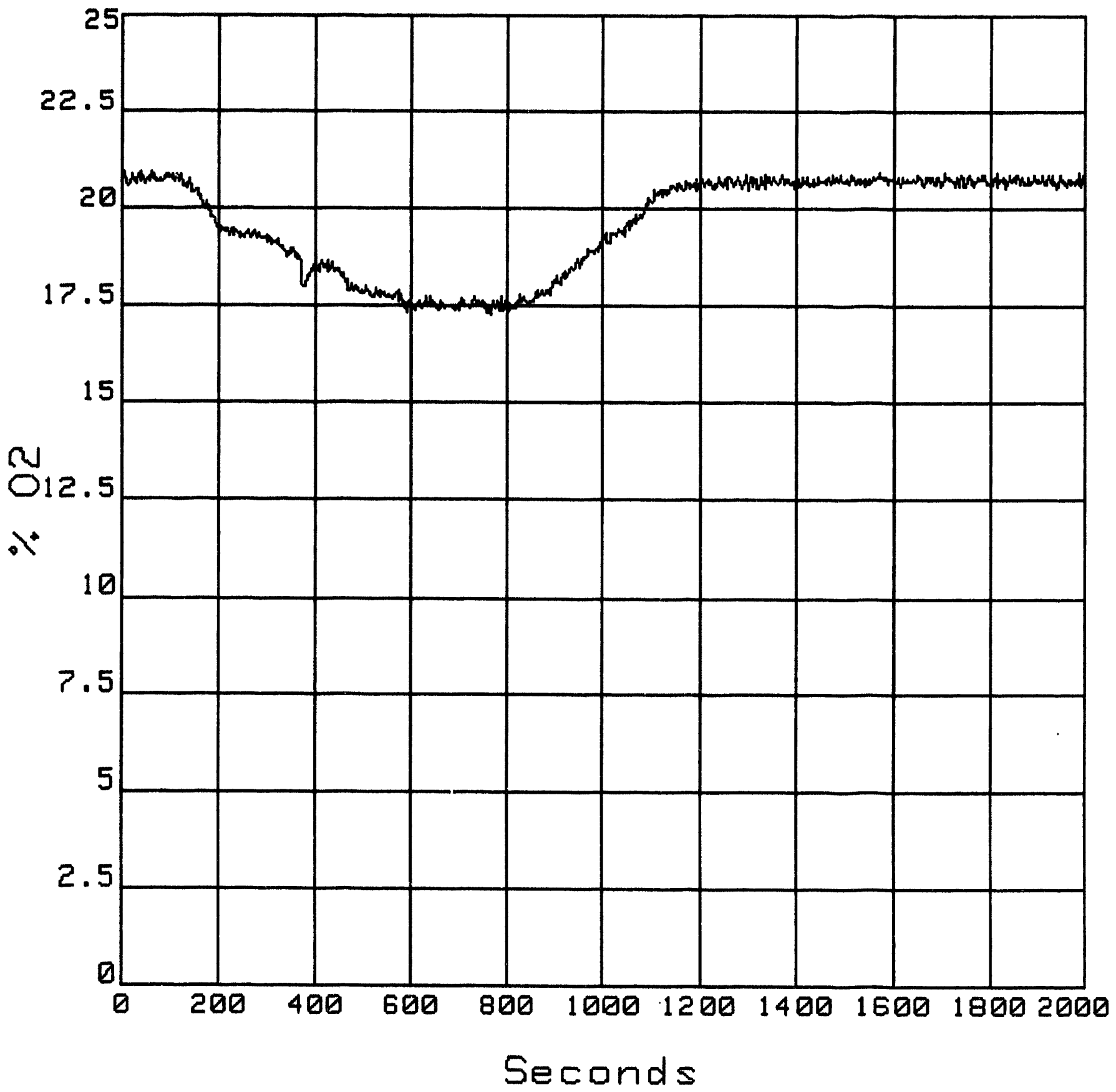

No. of channels $=27$ 
Rate: 7 Jun 19 ENT END

WDPAN 1

$\% \operatorname{CO} 2$

Time: 10:02:43

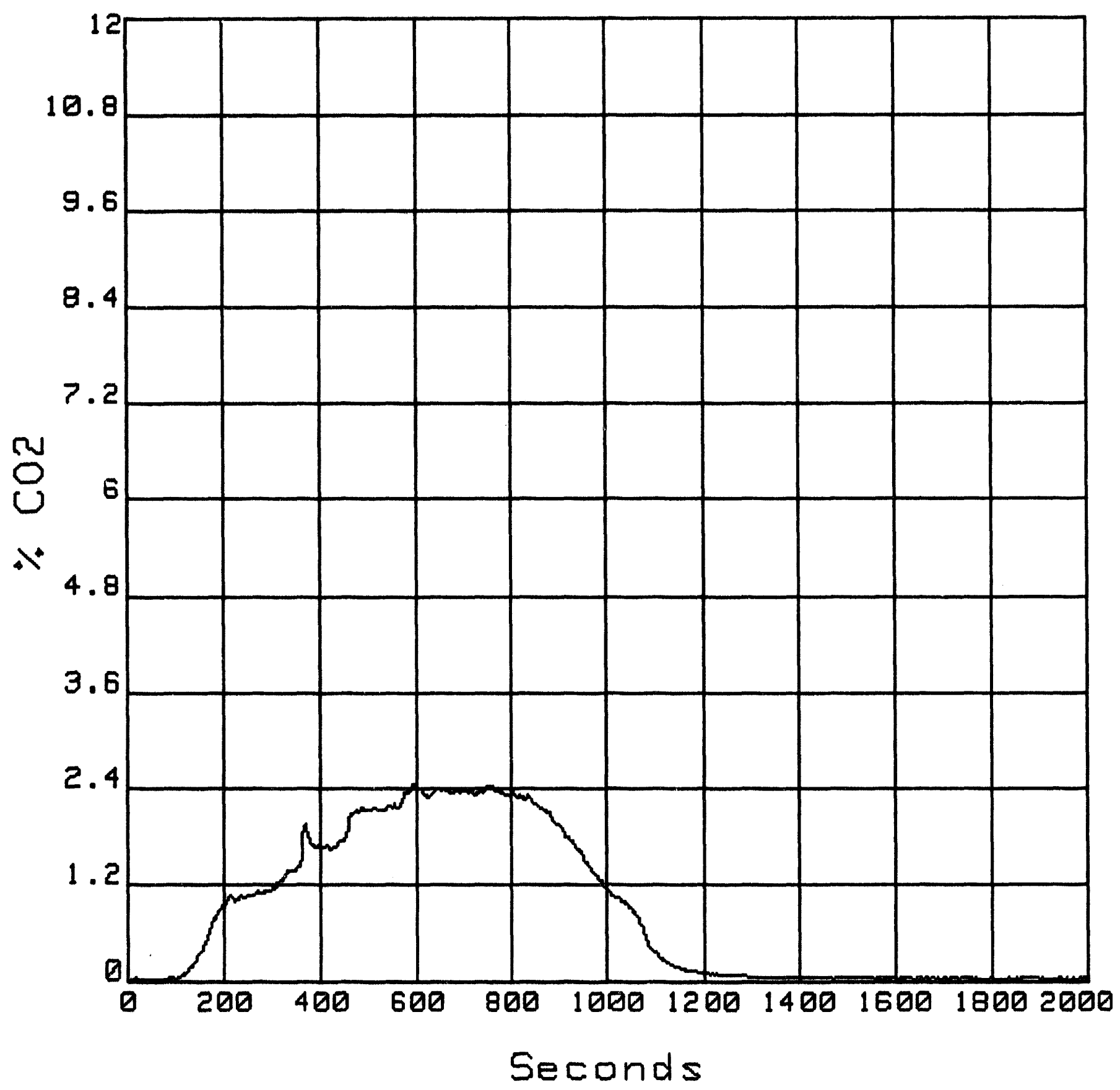

No. of channels $=27$ 
$\begin{array}{ccc}\text { Date: } & \text { WDPAN J Jun 19 } & \text { Time: } 10: 02: 43 \\ \text { CH-82 } & \text { CO ERST END } & \% \text { co }\end{array}$

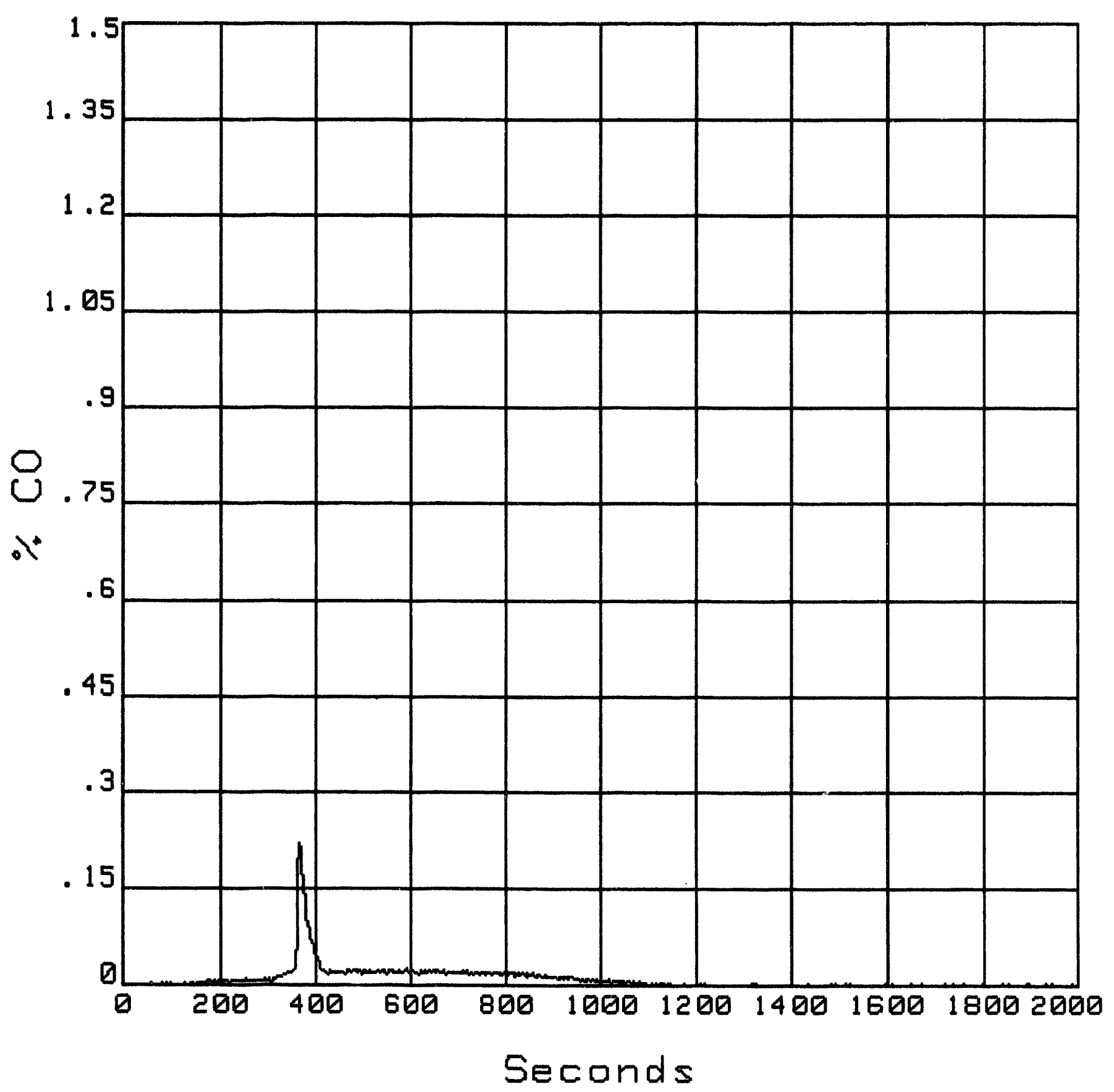

No. of channels $=27$ 


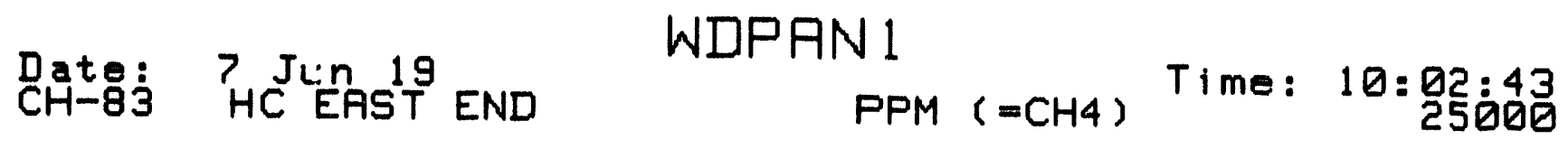

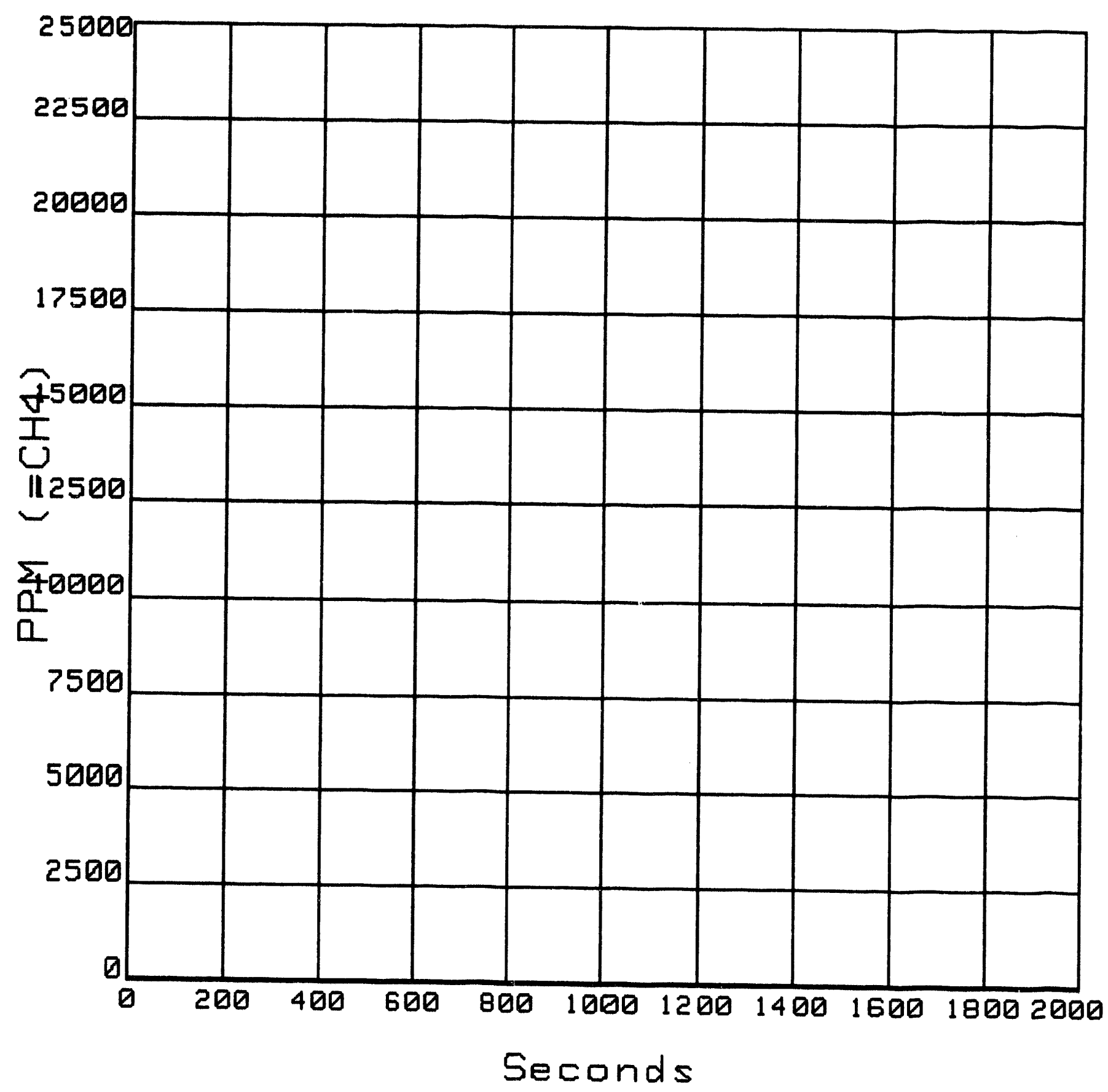

No. of channels $=27$ 
Date: 7 Jun 19 OL WEST END

WDPAN 1

$\% 02$

Time: 10:02: $\frac{43}{25}$

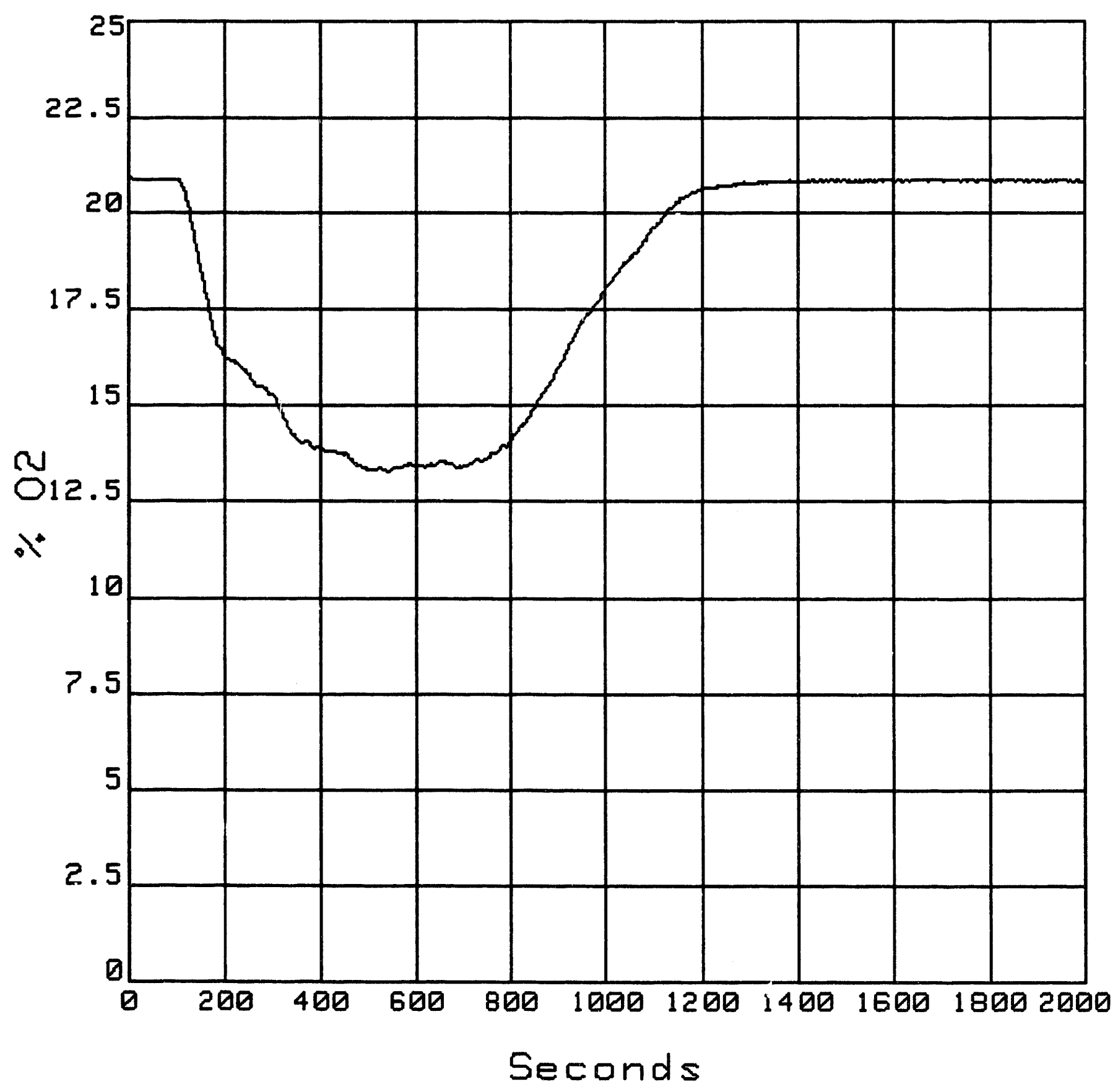

No. of channels $=27$ 
$\begin{array}{ccc}\text { Date: } & \text { WDPAN } 19 \\ \text { CH-85 COZ WEST END } & \% \text { CO2 Time: 10:02:43 } \\ 13\end{array}$

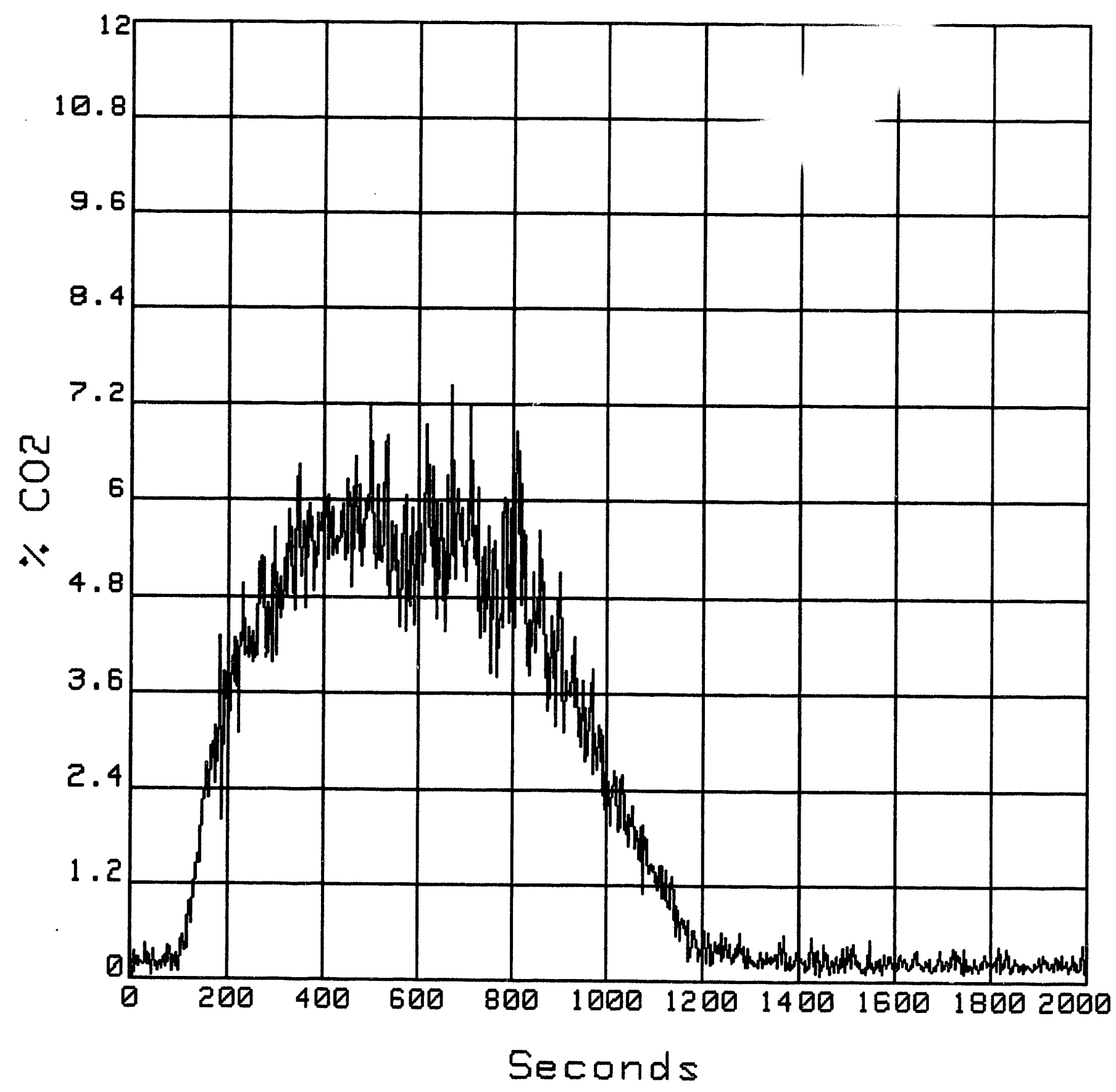

No. of channels $=27$ 


\section{WDPAN 1}

Date: ? Jun 19 TH

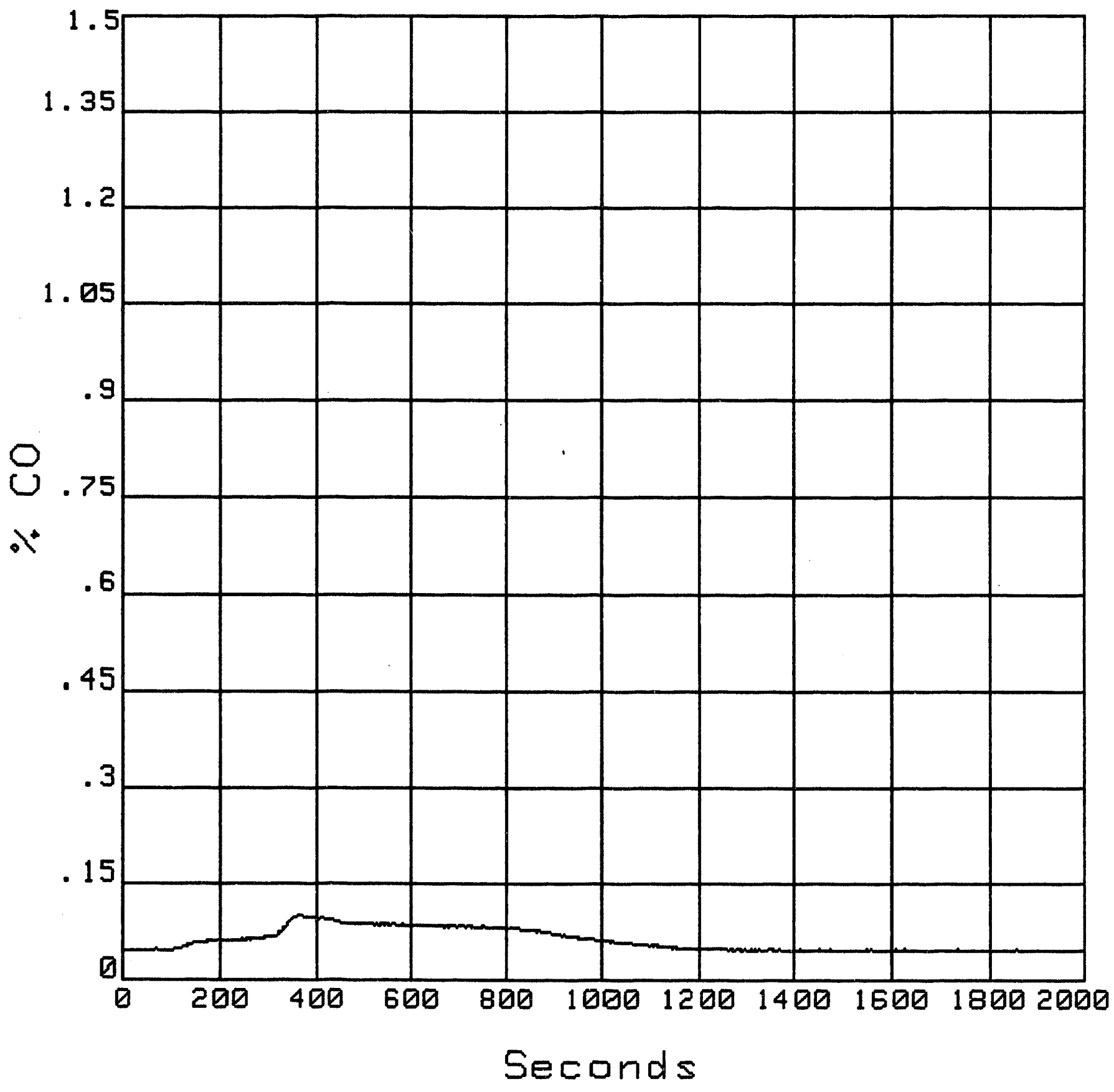

No. of channels $=27$ 
Date: THJun 19 TCND

WDPRN 1

PPM ( $=\mathrm{CH} 4)$ Time: 10:02:43

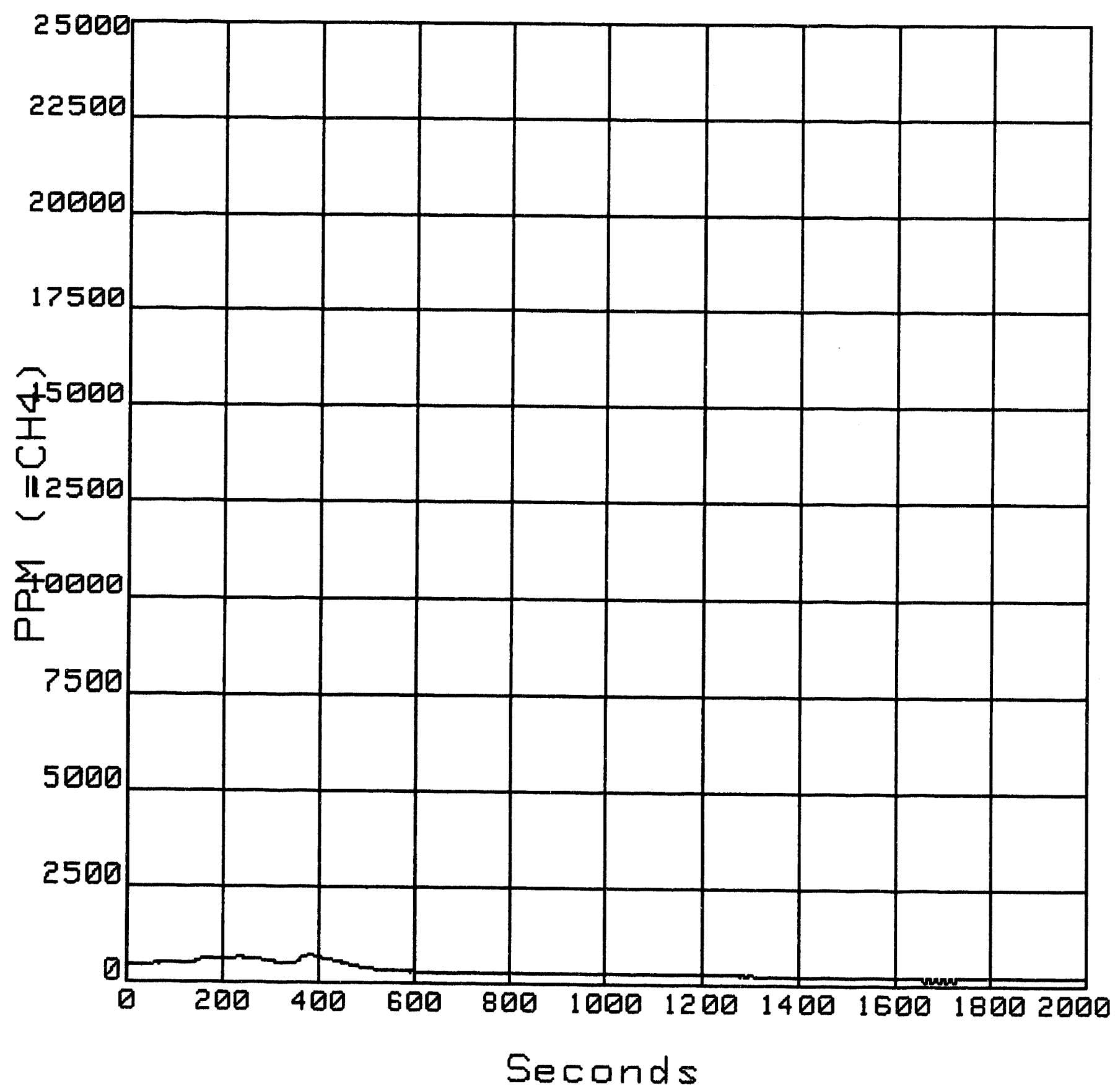

No. of channels $=27$ 
Date: 7o Jun 19 Duct Node

WDPAN 1

$\% 02$

Time: 10:02: $\frac{43}{25}$

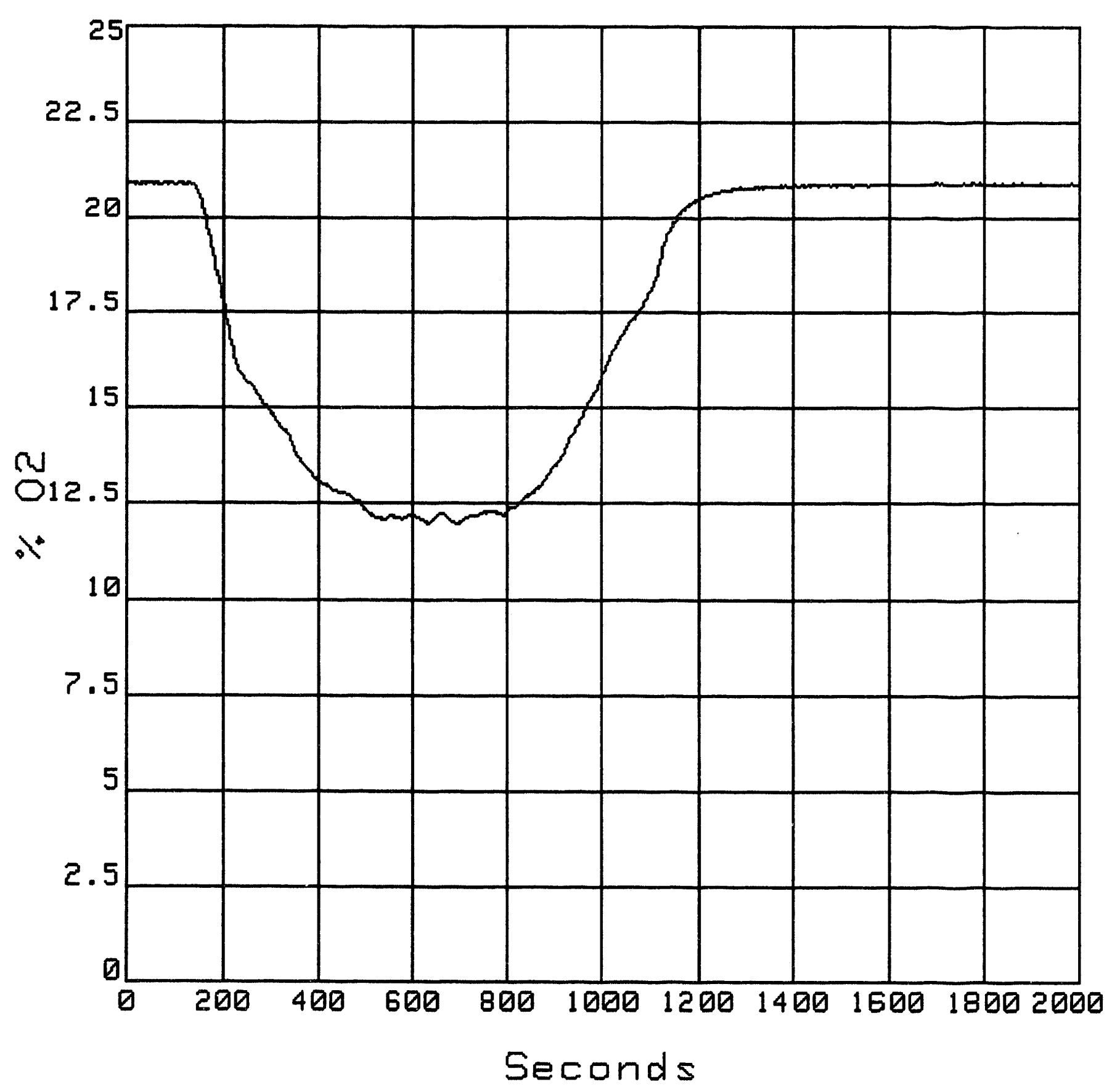

No. of channels $=27$ 


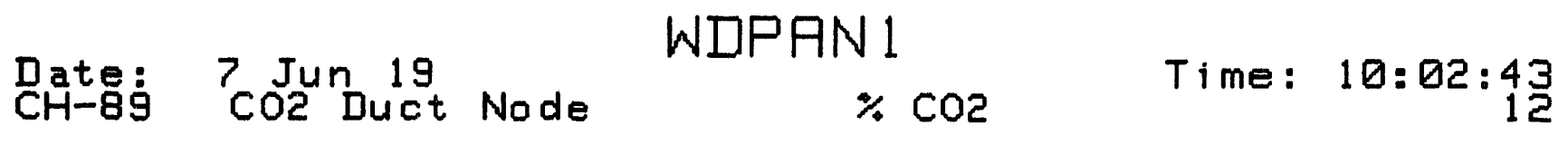

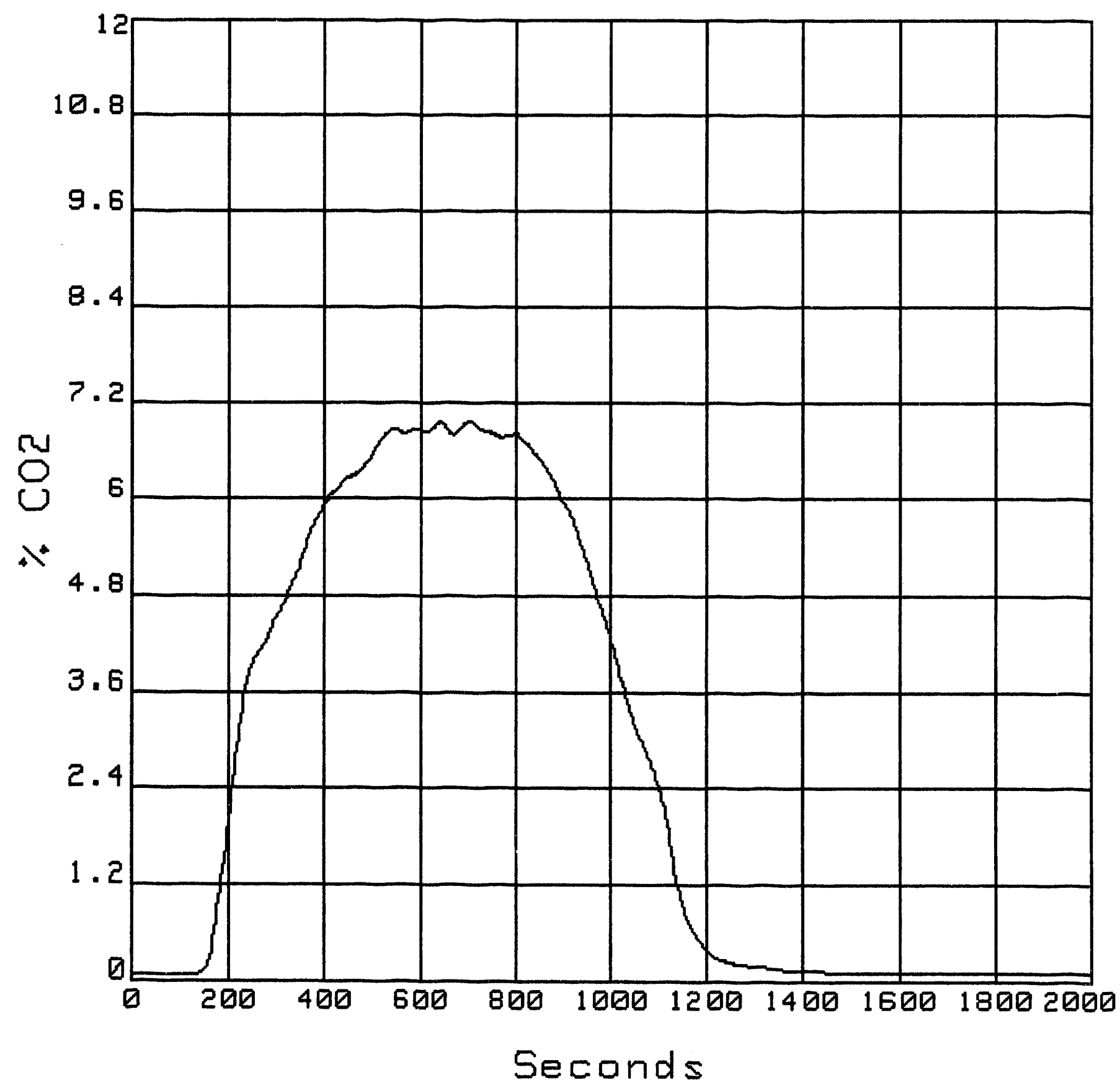

No. of channels $=27$ 
$\begin{array}{cccc}\text { Date: } & \text { WDPAn } 19 & \text { Time: } 10: 02: 43 \\ \text { CH-9un } & \text { Co Duct Node } & \% \text { co } & \text { Time }\end{array}$

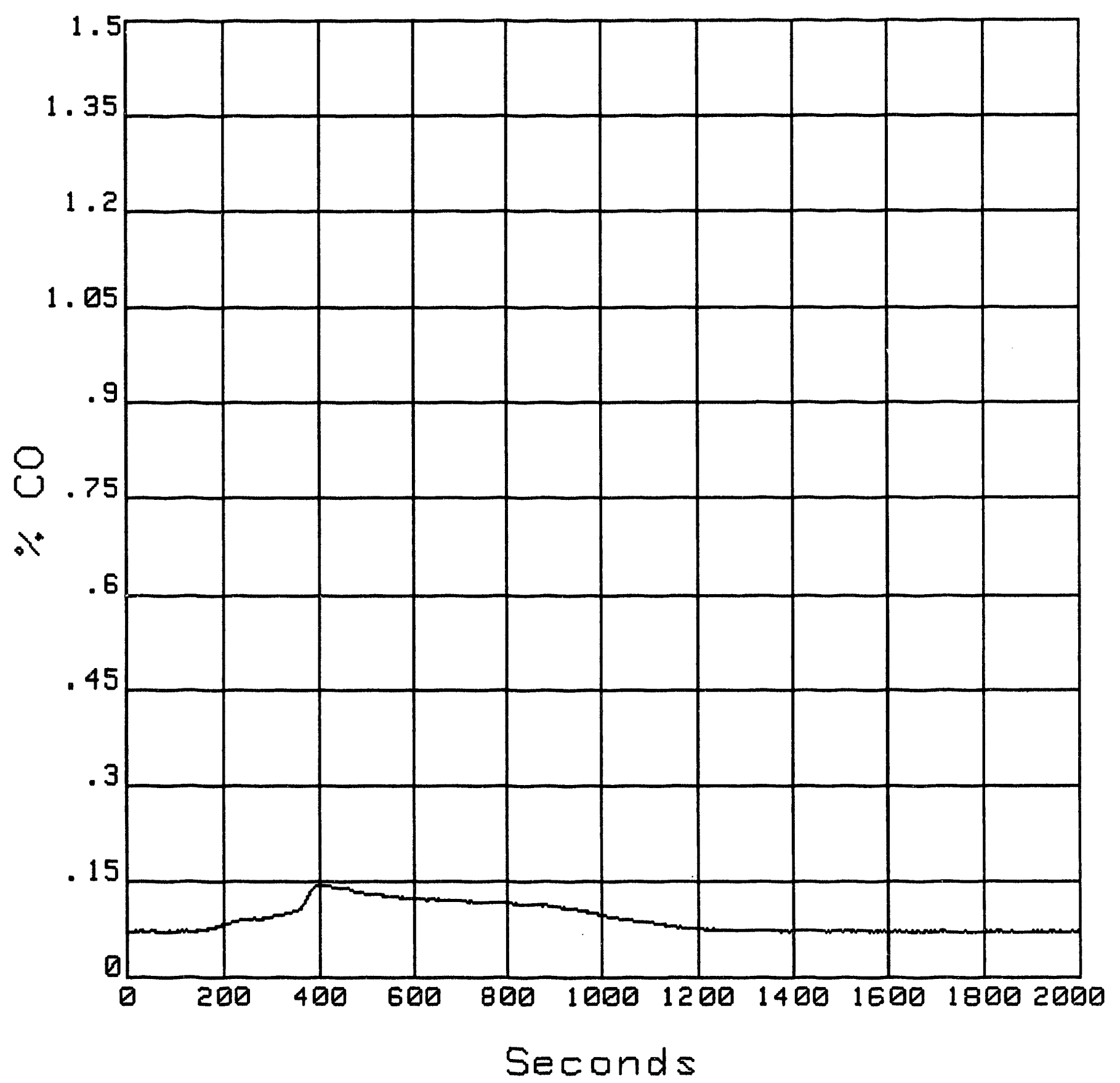

No. of channels $=27$ 
Date: PHun 19 Node

WDPAN 1

PPM ( $=\mathrm{CH} 4)$ Time: 10: $\frac{02: 43}{2500}$

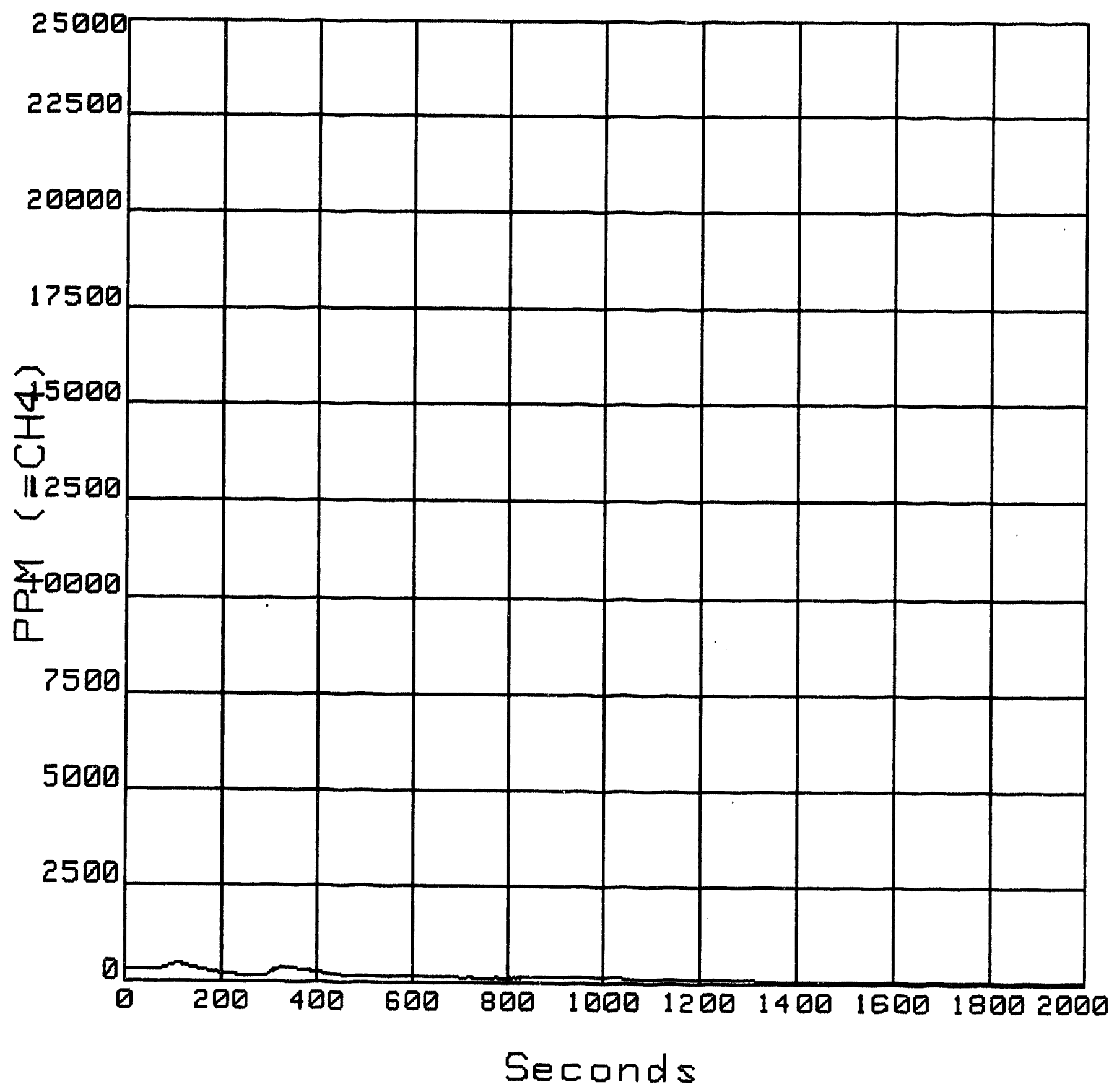

No. of channels $=27$ 
Date: $\quad$ Jun 19

WDPAN 1

PSI

Time: 10:02:43

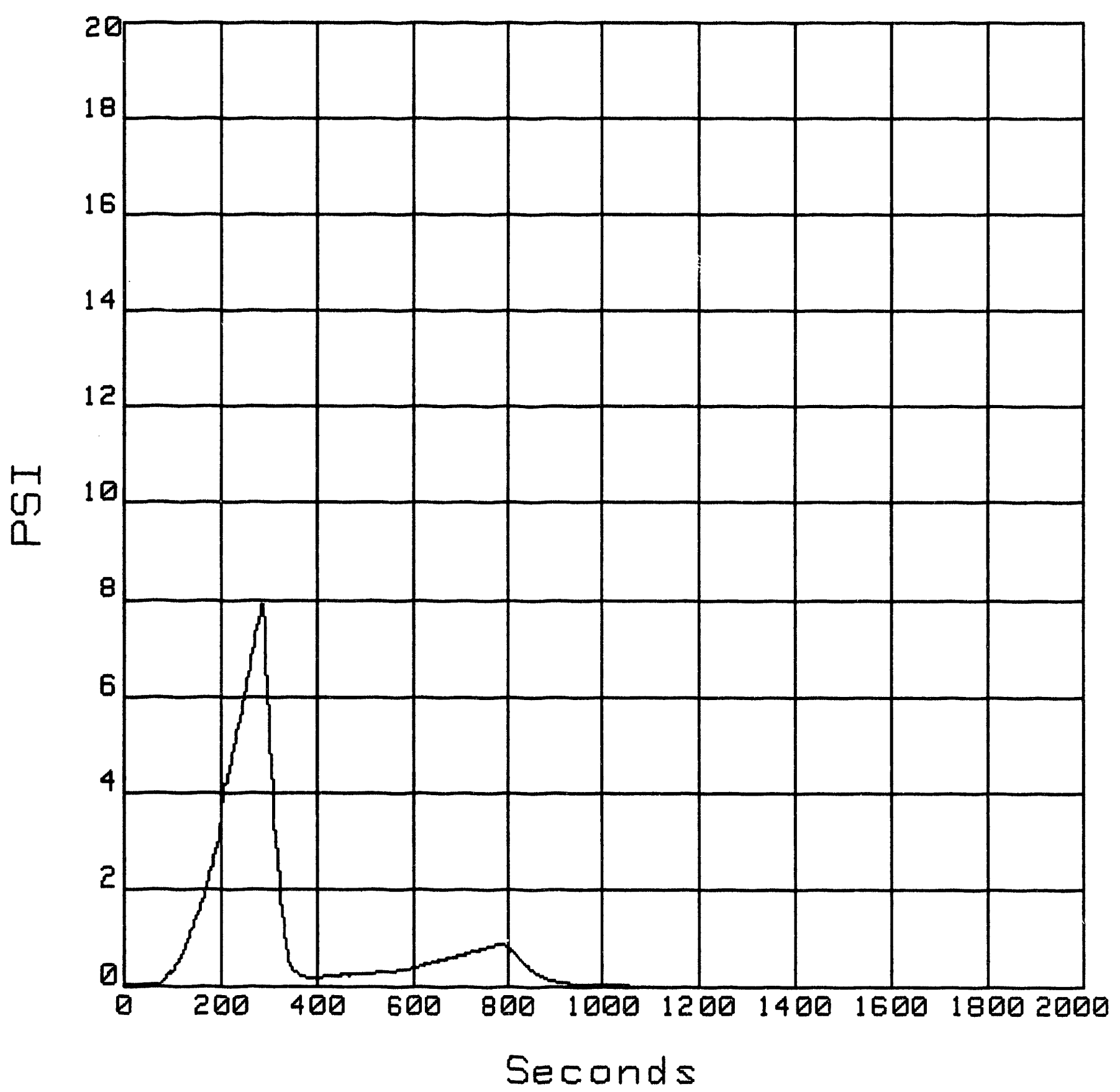

No. of channels $=27$ 

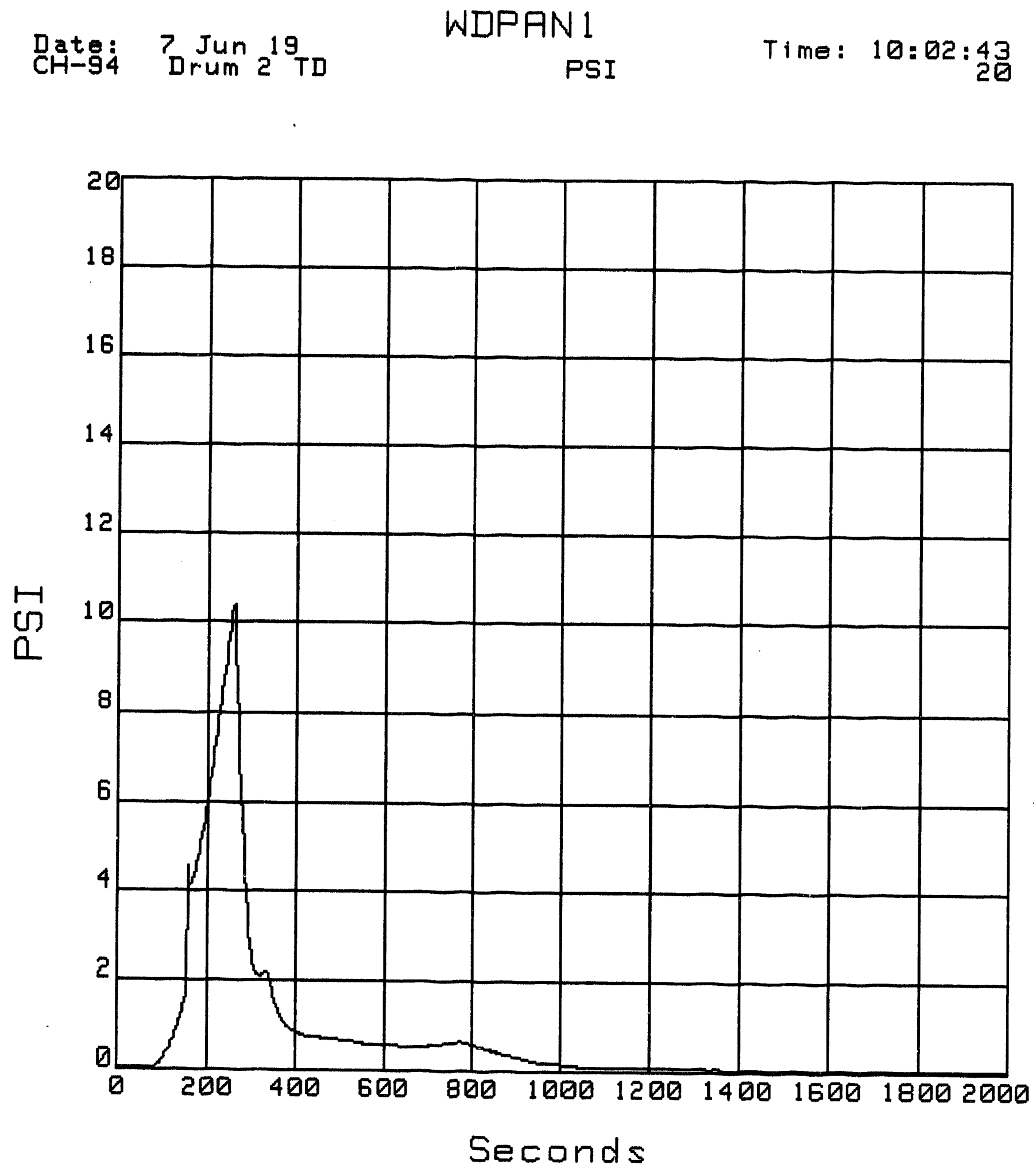

No. of channels $=27$ 

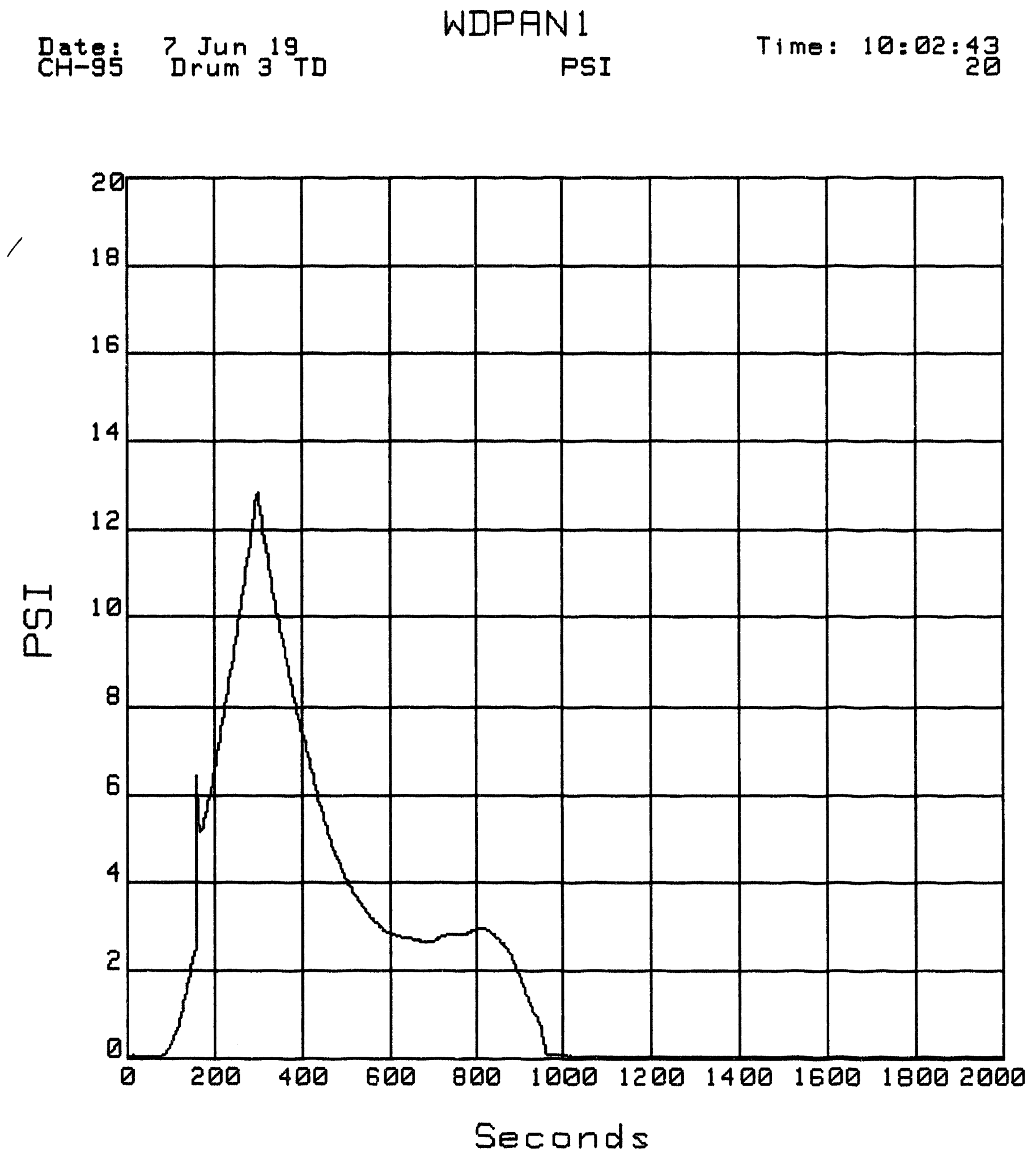

No. of channels $=27$ 
Date: CHun $_{\text {Drum }} 4{ }^{19}$

WDPAN 1

PSI

Time: 10:02:43

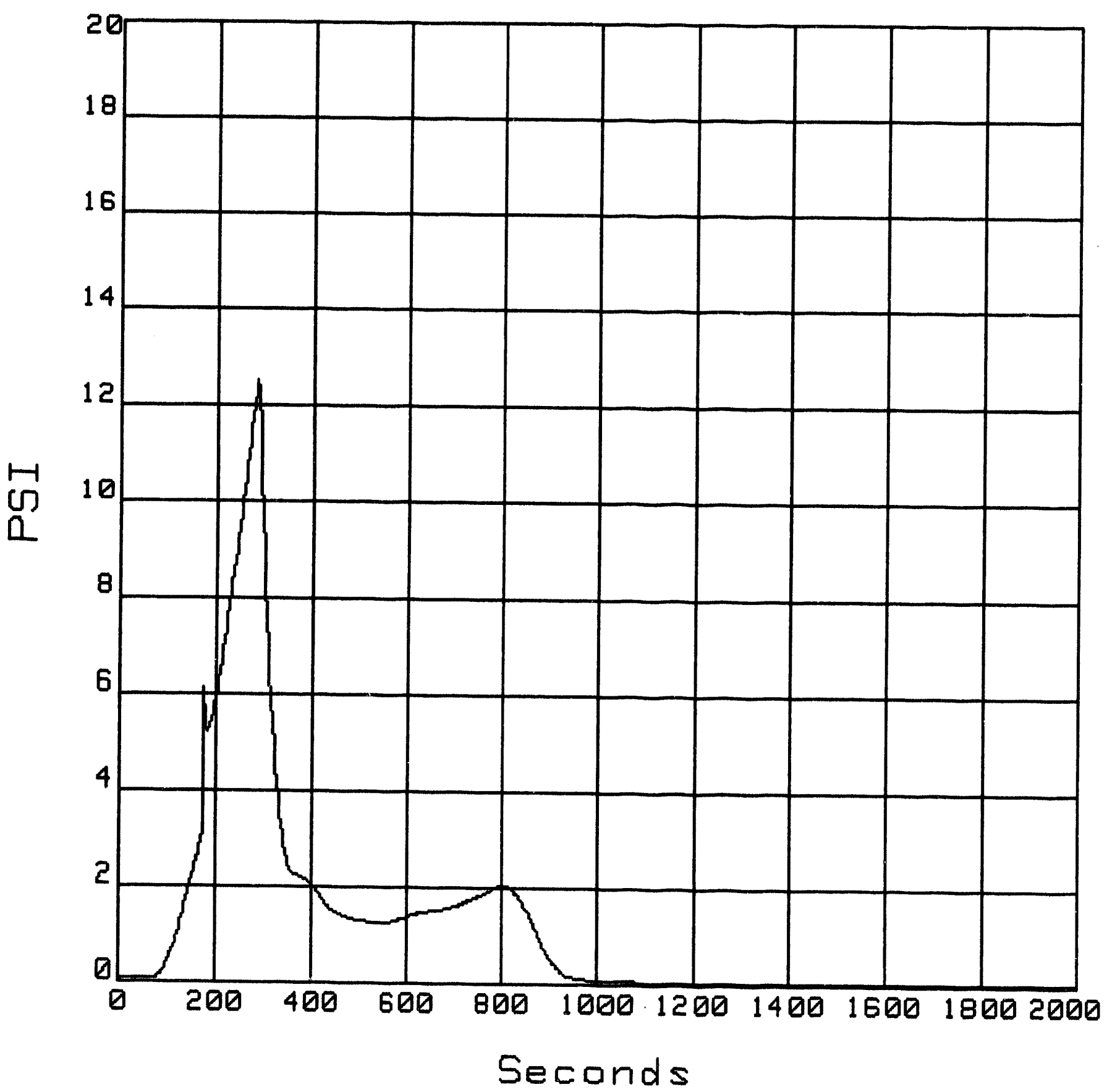

No. of channels $=27$ 
WDPANE

Date: 14 Jun 19 Fir

Time: $11: 48: 44$
Isius

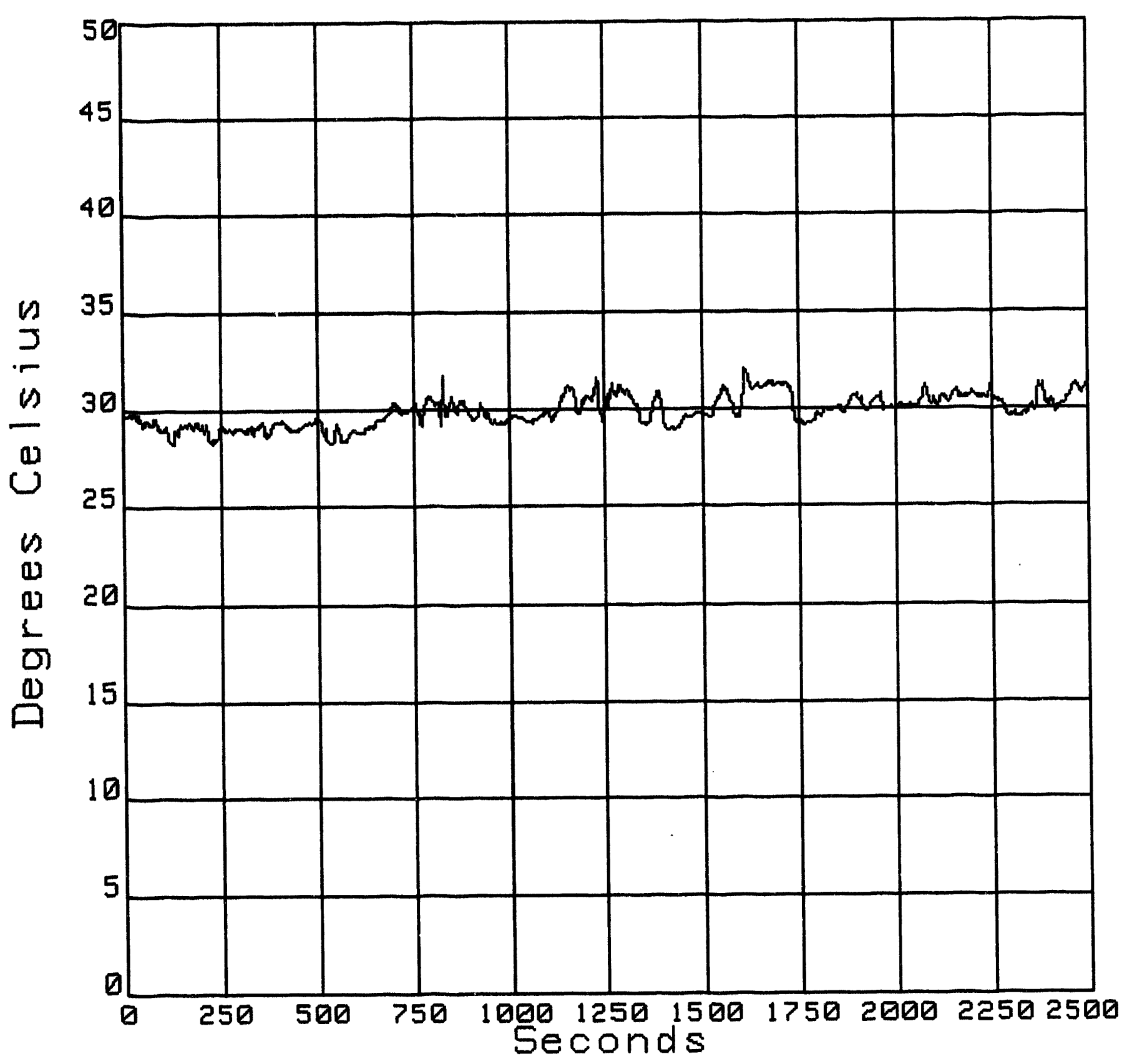

No. of channels $=27$ 
Date: 14 Jun 19

WDPAN2

Time: $11: 48: 44$
sius

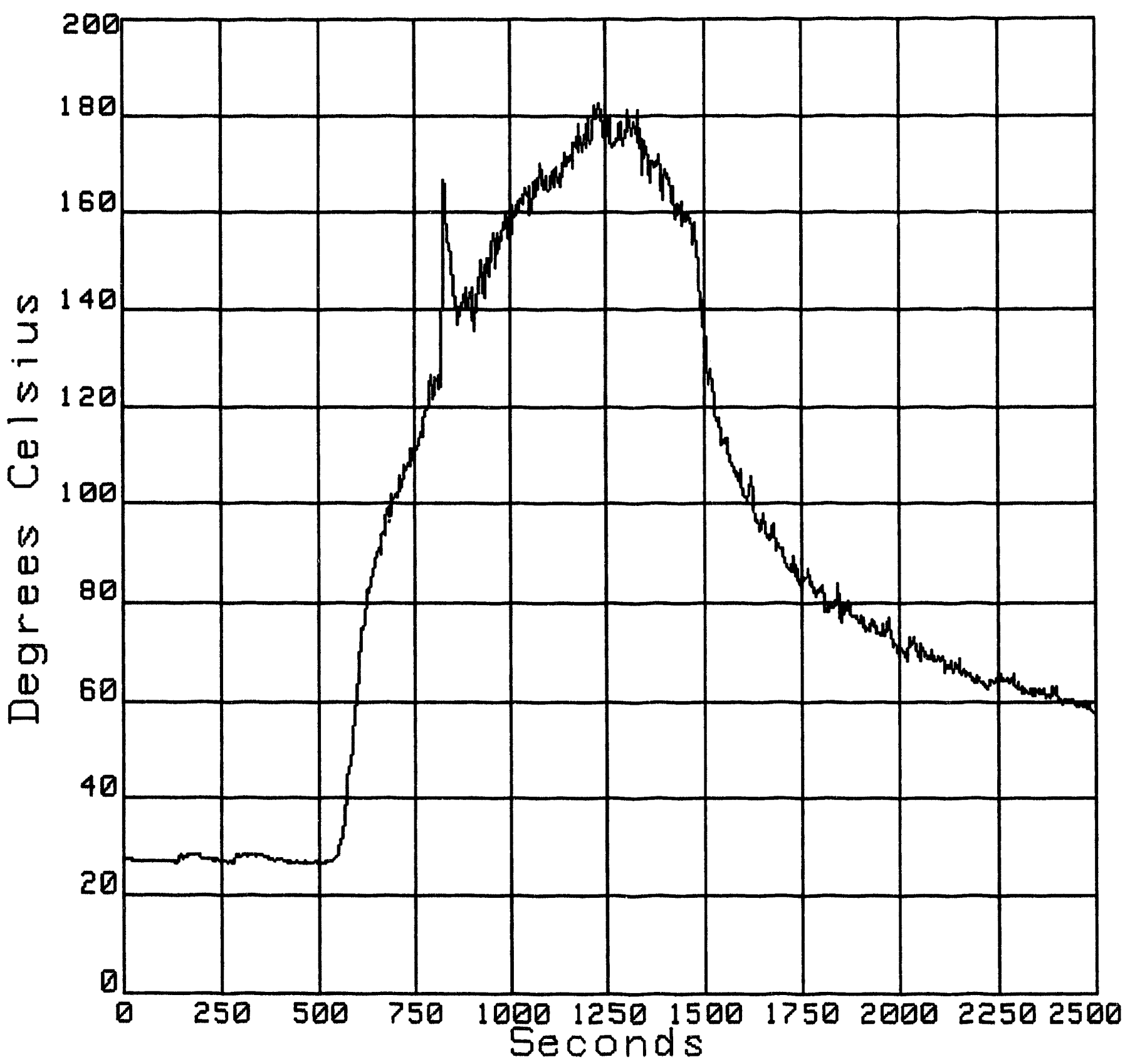

No. of channels $=27$ 


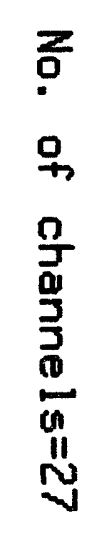

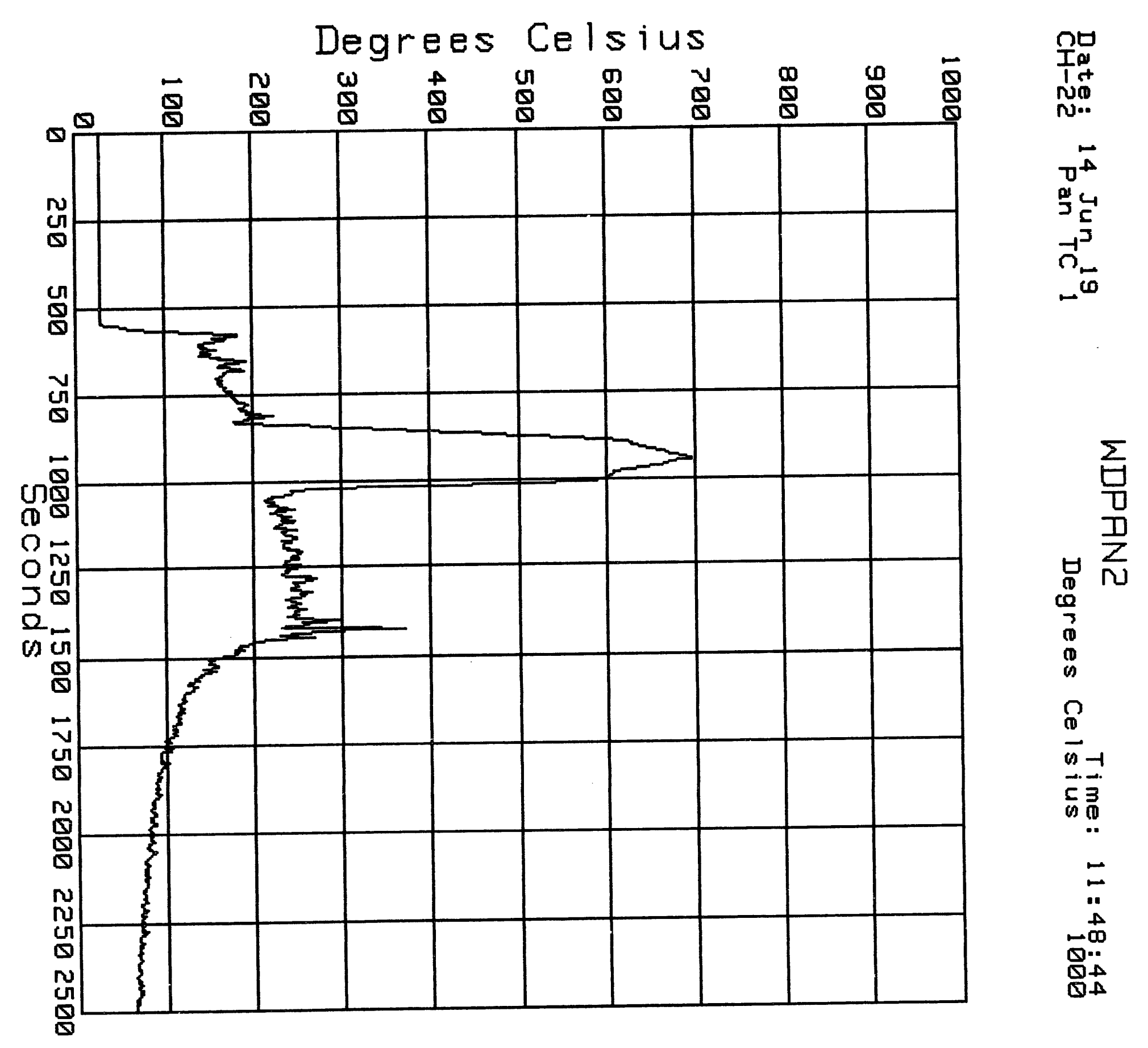


Date: 14 Jun 19

WDPAN2

Degrees Celsime: 11:48:44

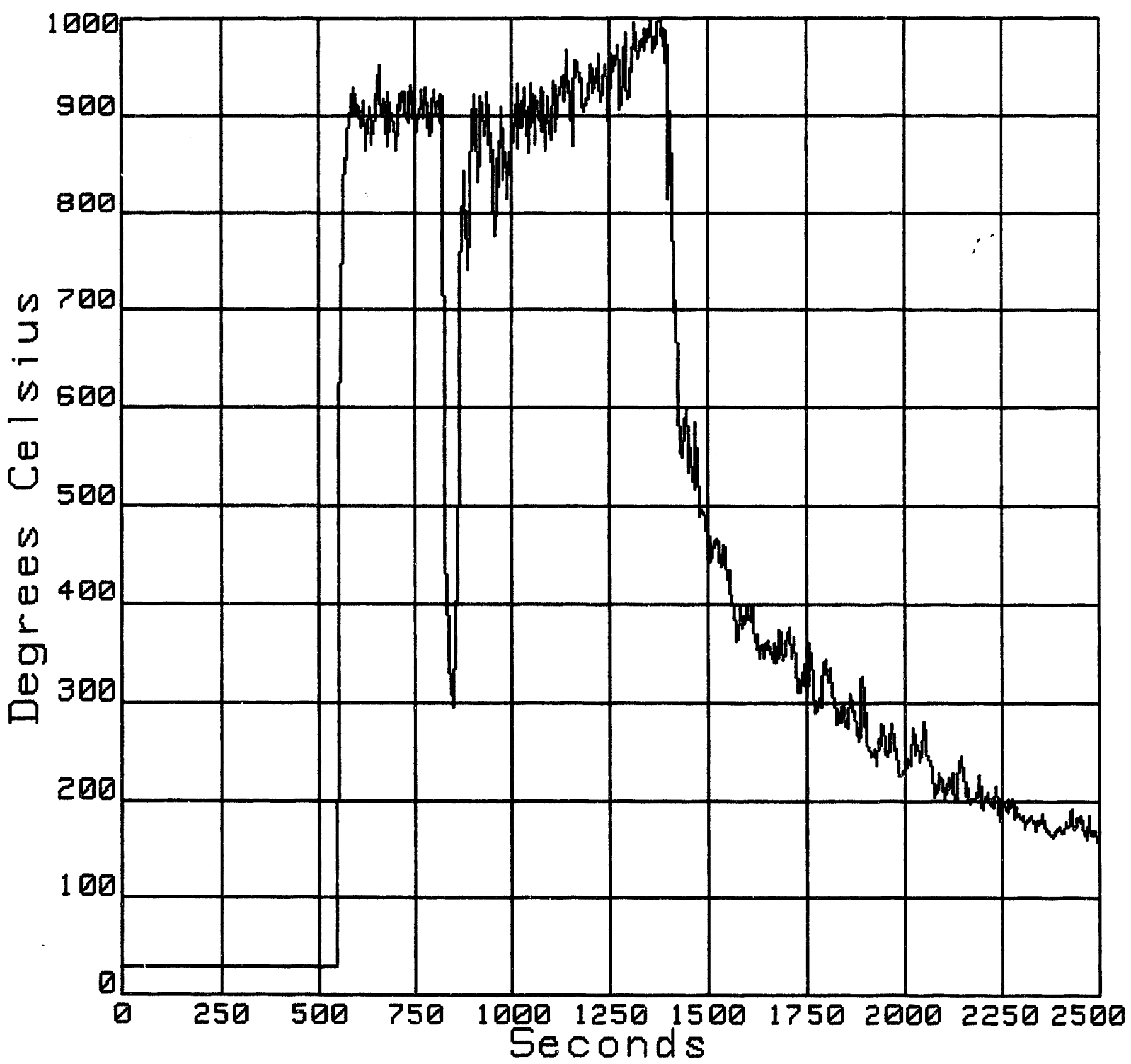

No. of channels $=27$ 
Date: 14 Jun 19

WDPAN2

Times: $11: 48: 44$
Degrees Celsius

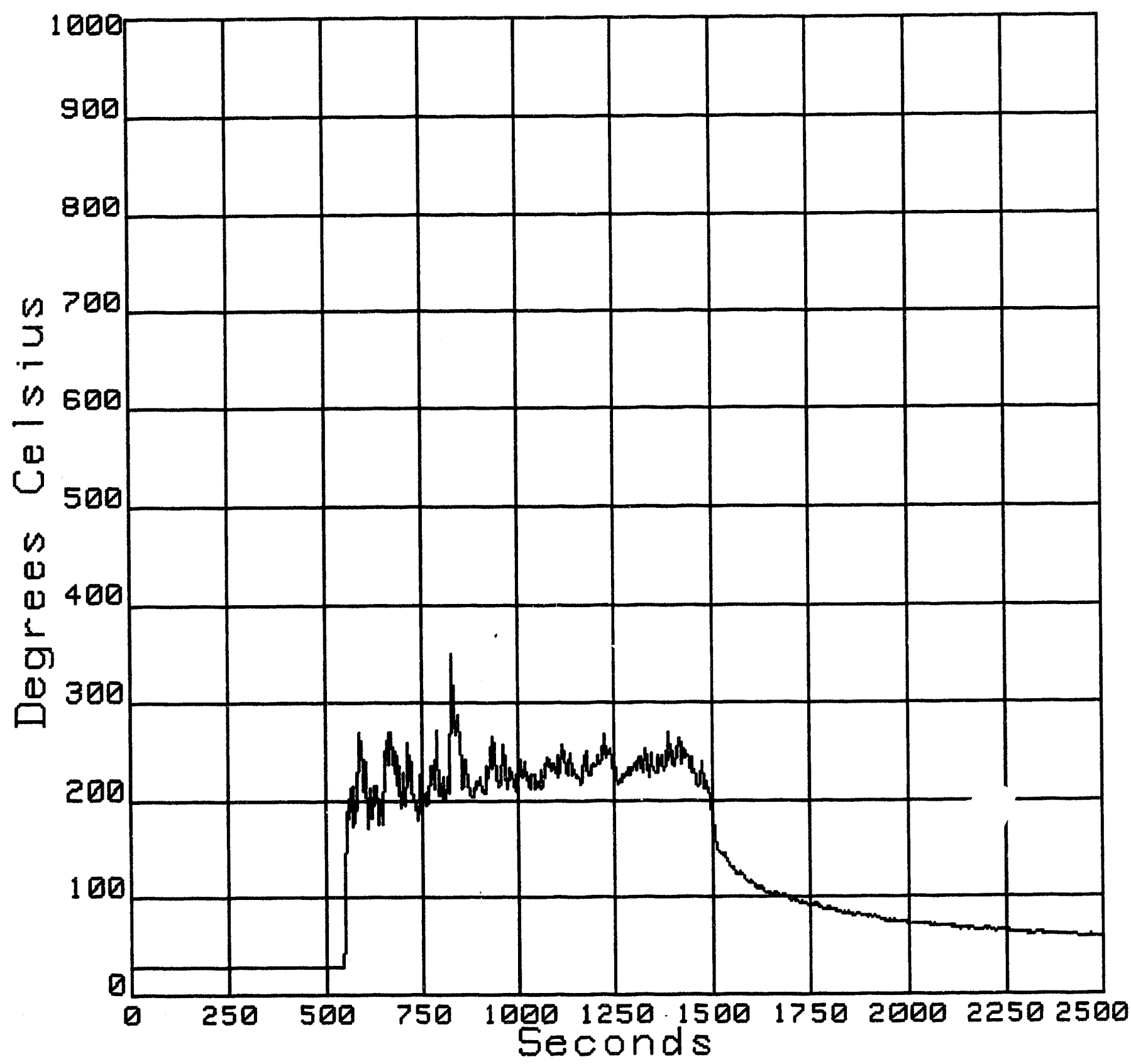

No. of channels $=27$ 
Date: 14 Jun 19

WDPAN2

Time: $11: 48: 44$

Degrees Celsius 10

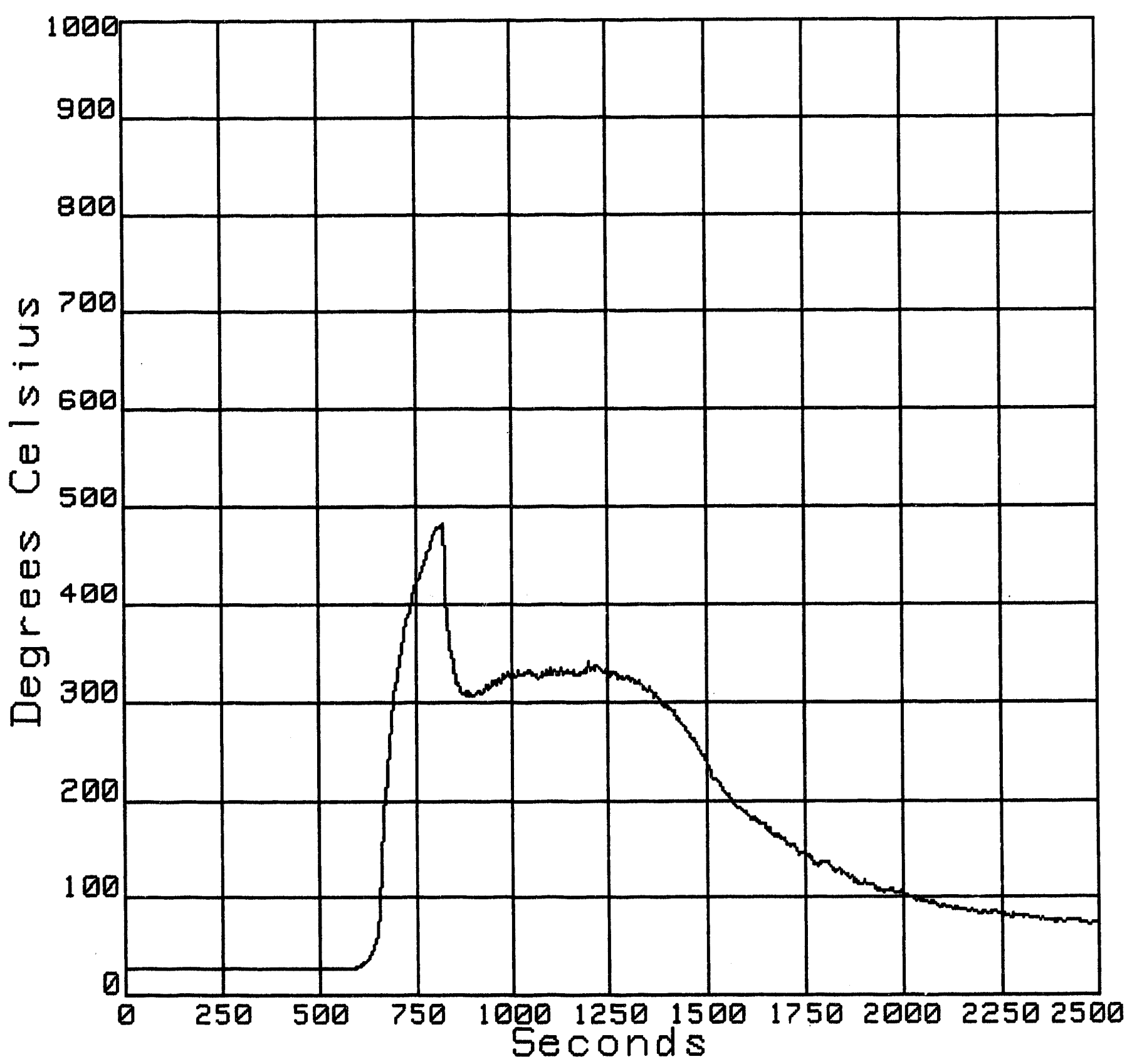

No. of channels $=27$ 
WDPAN2

Date: 14 Jun $2^{19}$ TC

Degrees Celsius : $11: 48: 44$

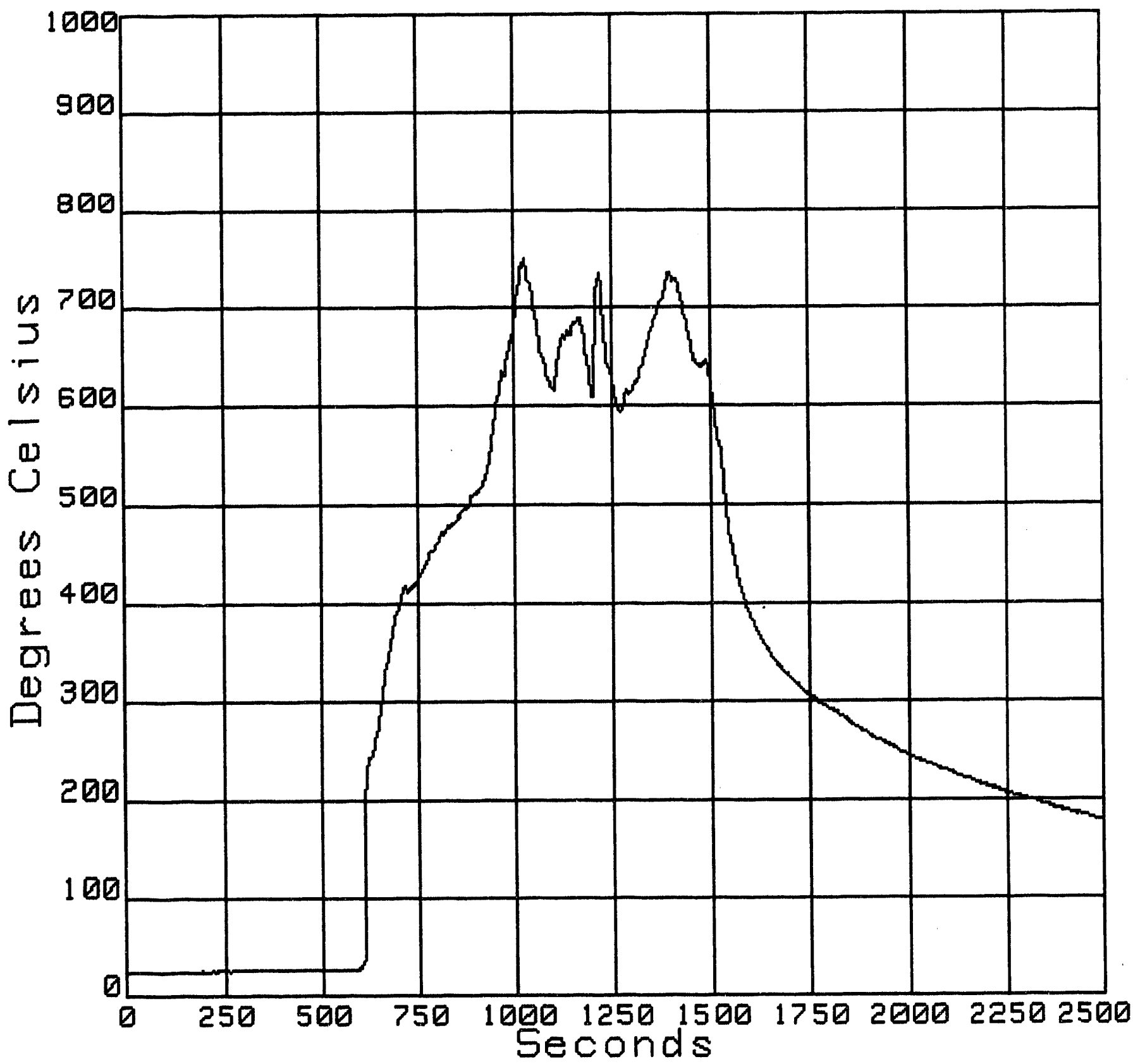

No. of channels $=27$ 


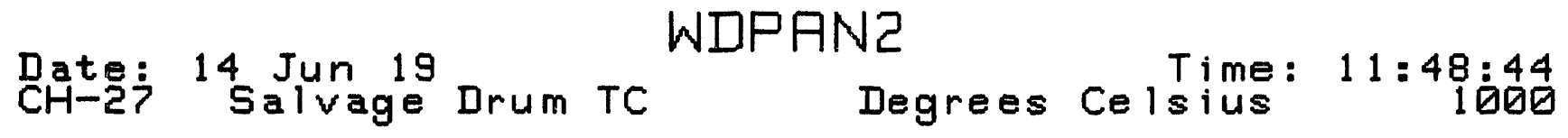

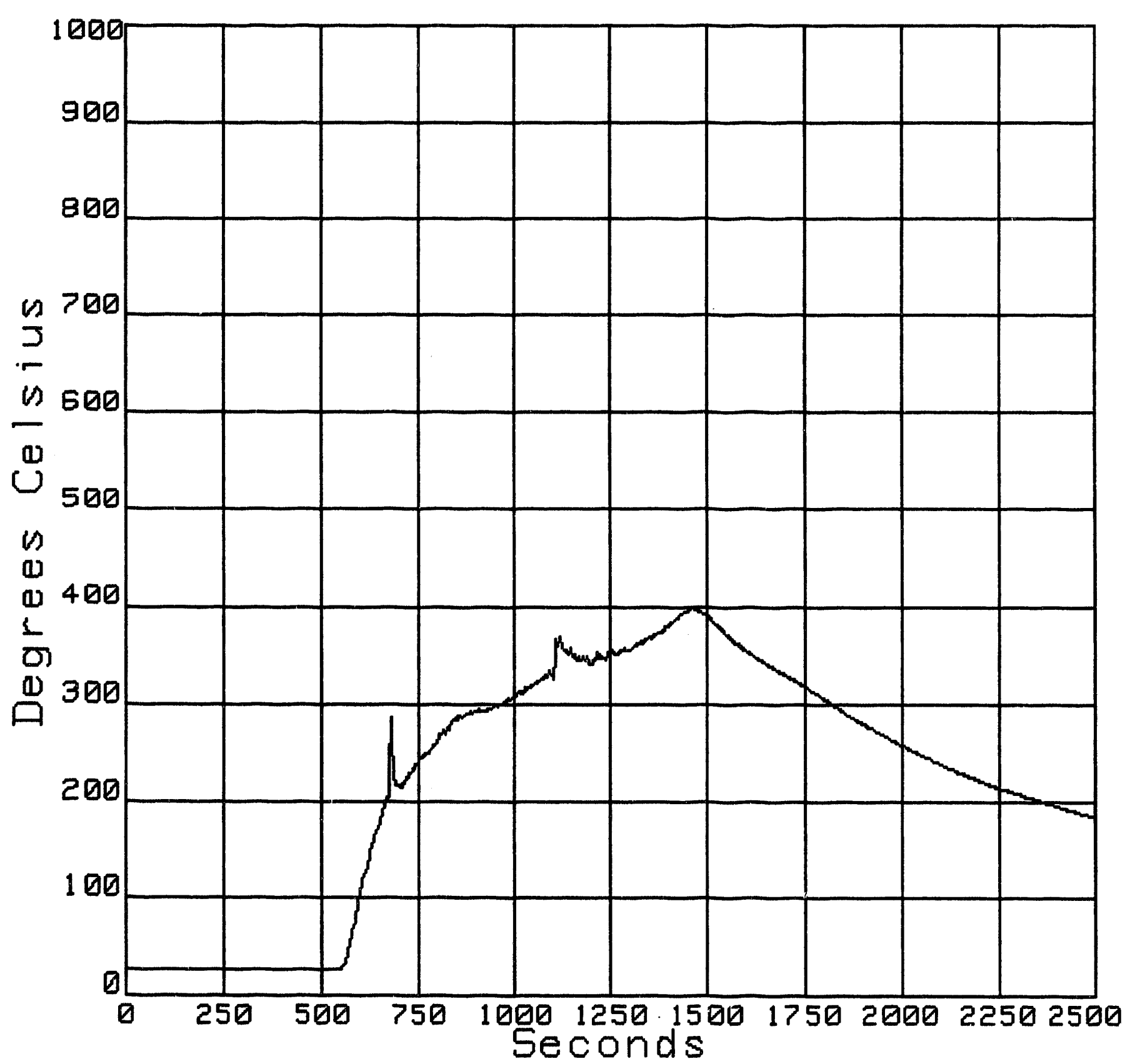

No. of channels $=27$ 


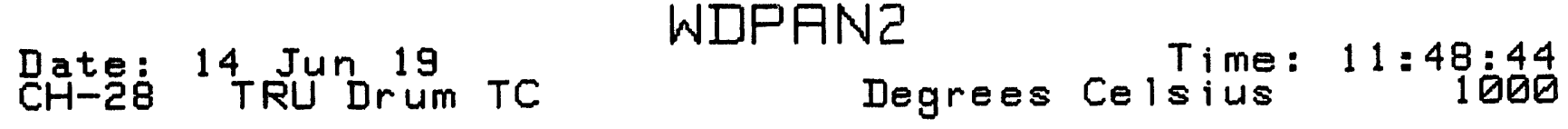

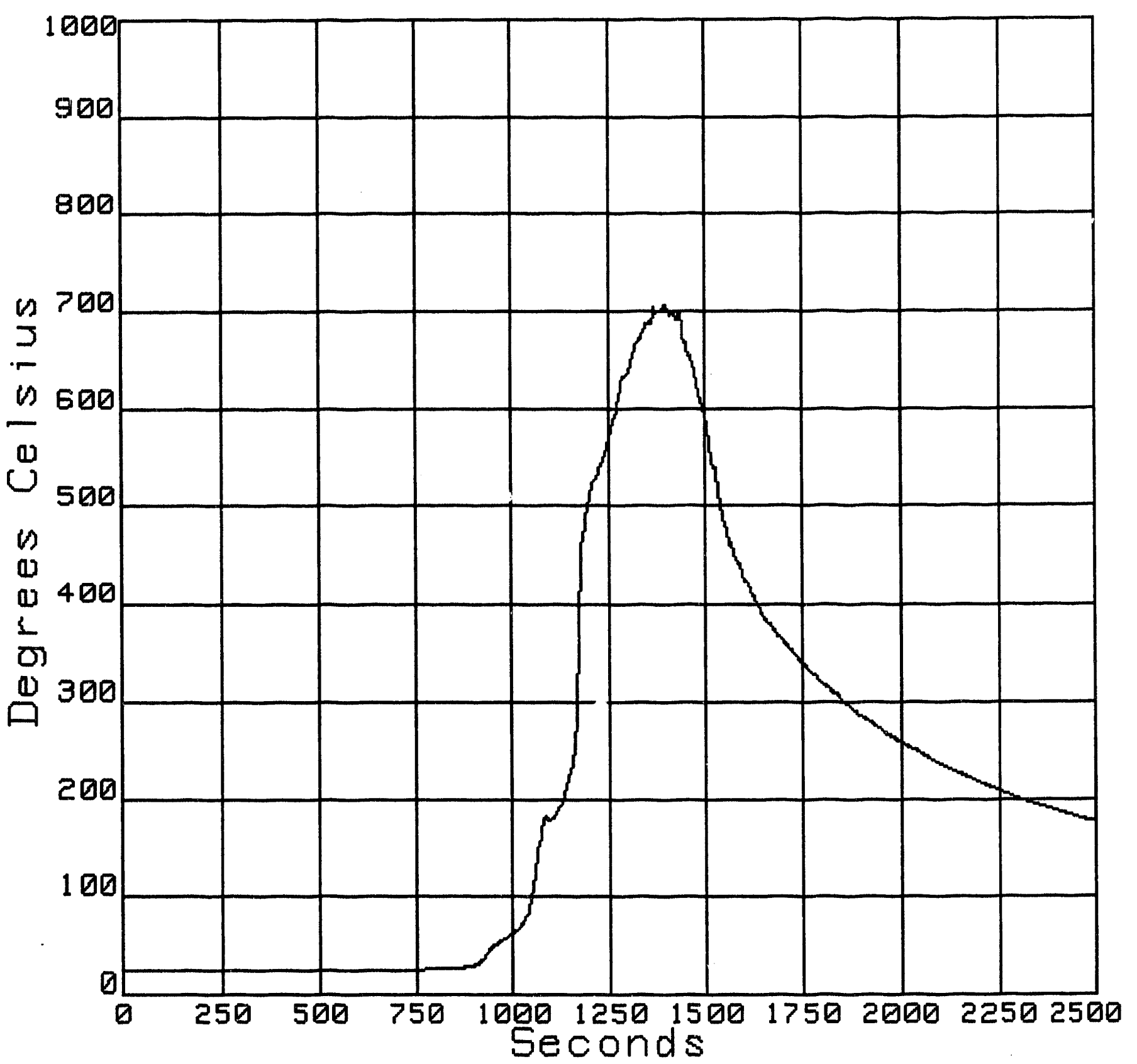

No. of channels $=27$ 
Date: 14 Jun 19 CH-2̇ Inner Drum TC
WDPAN2

Degrees Celsius $11: 48: 44$

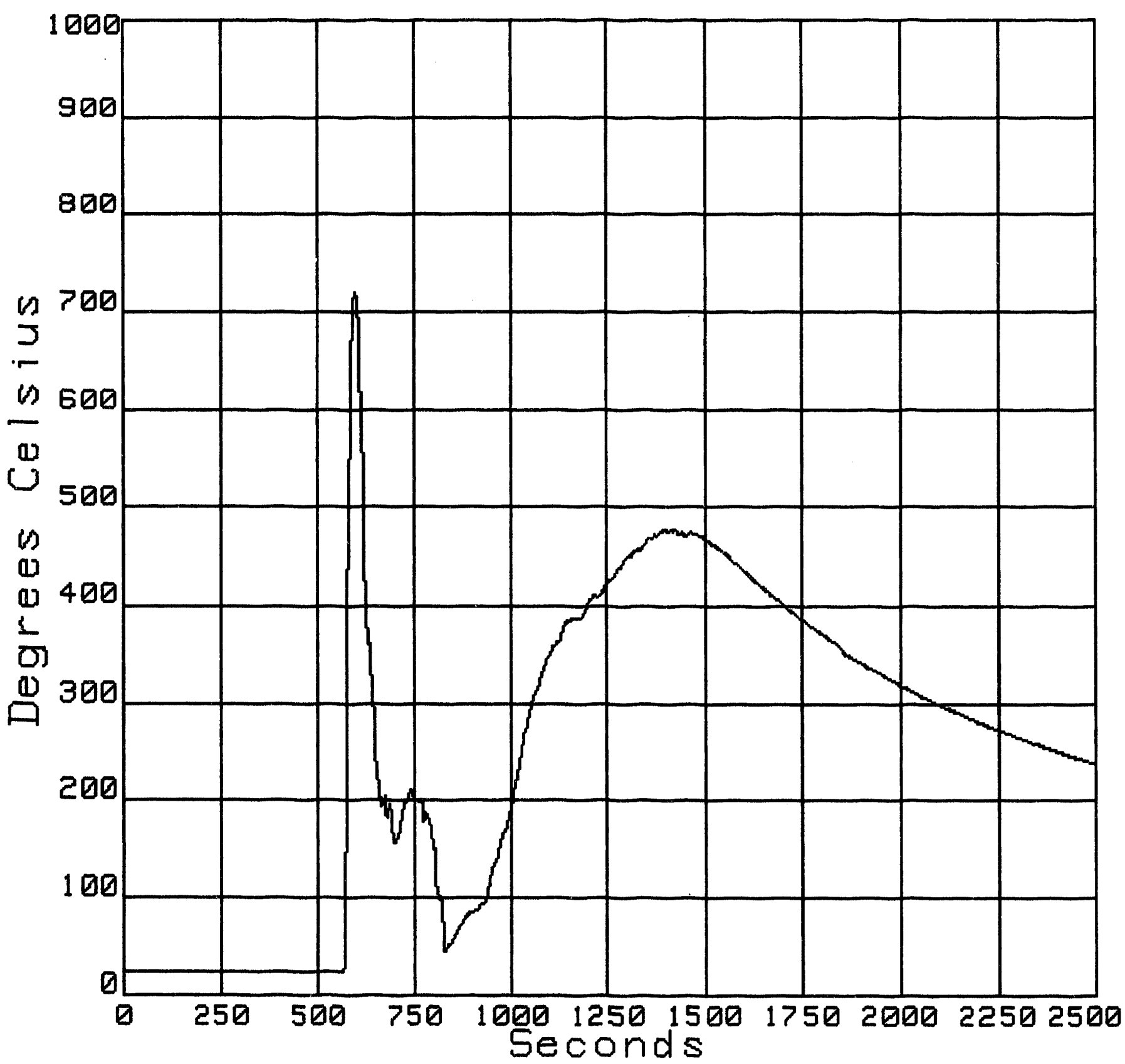

No. of channels $=27$ 


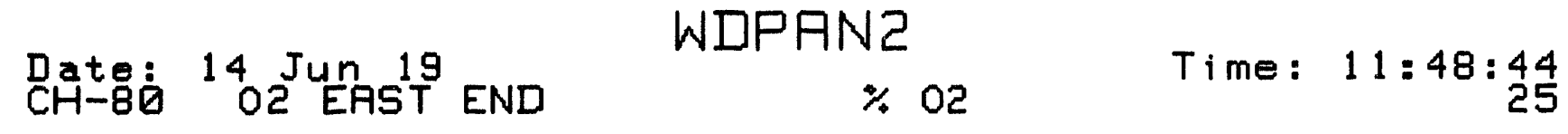

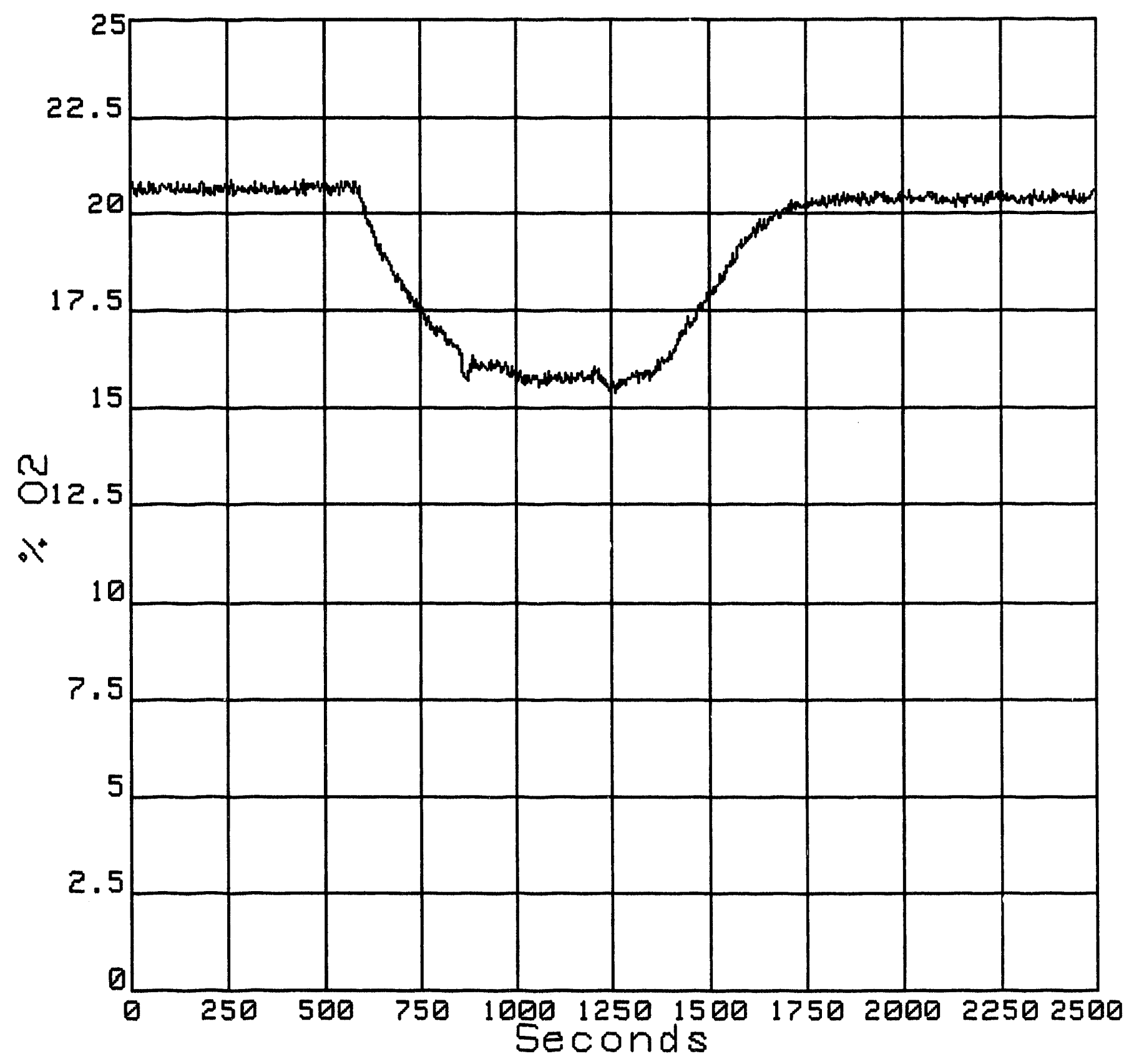

No. of channels $=27$ 


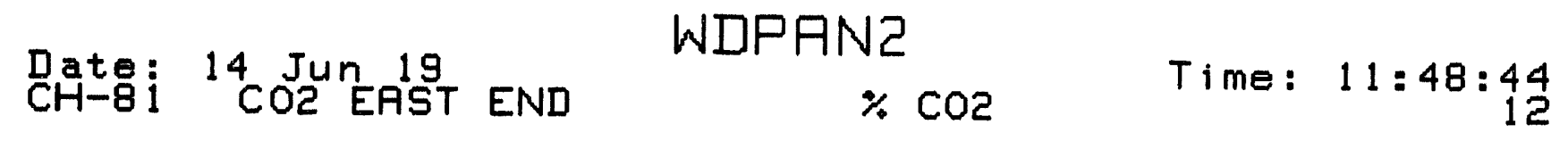

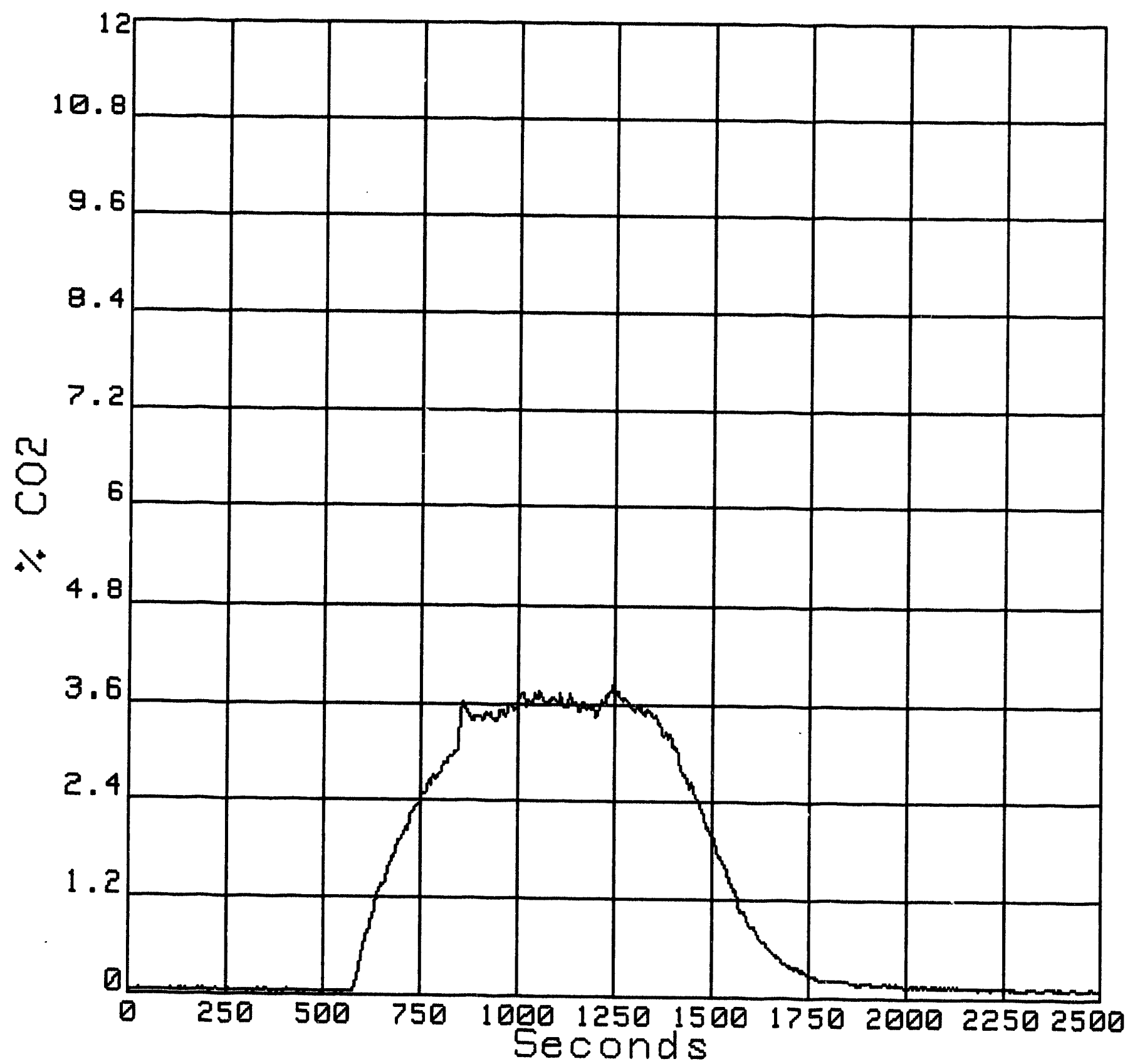

No. of channels $=27$ 

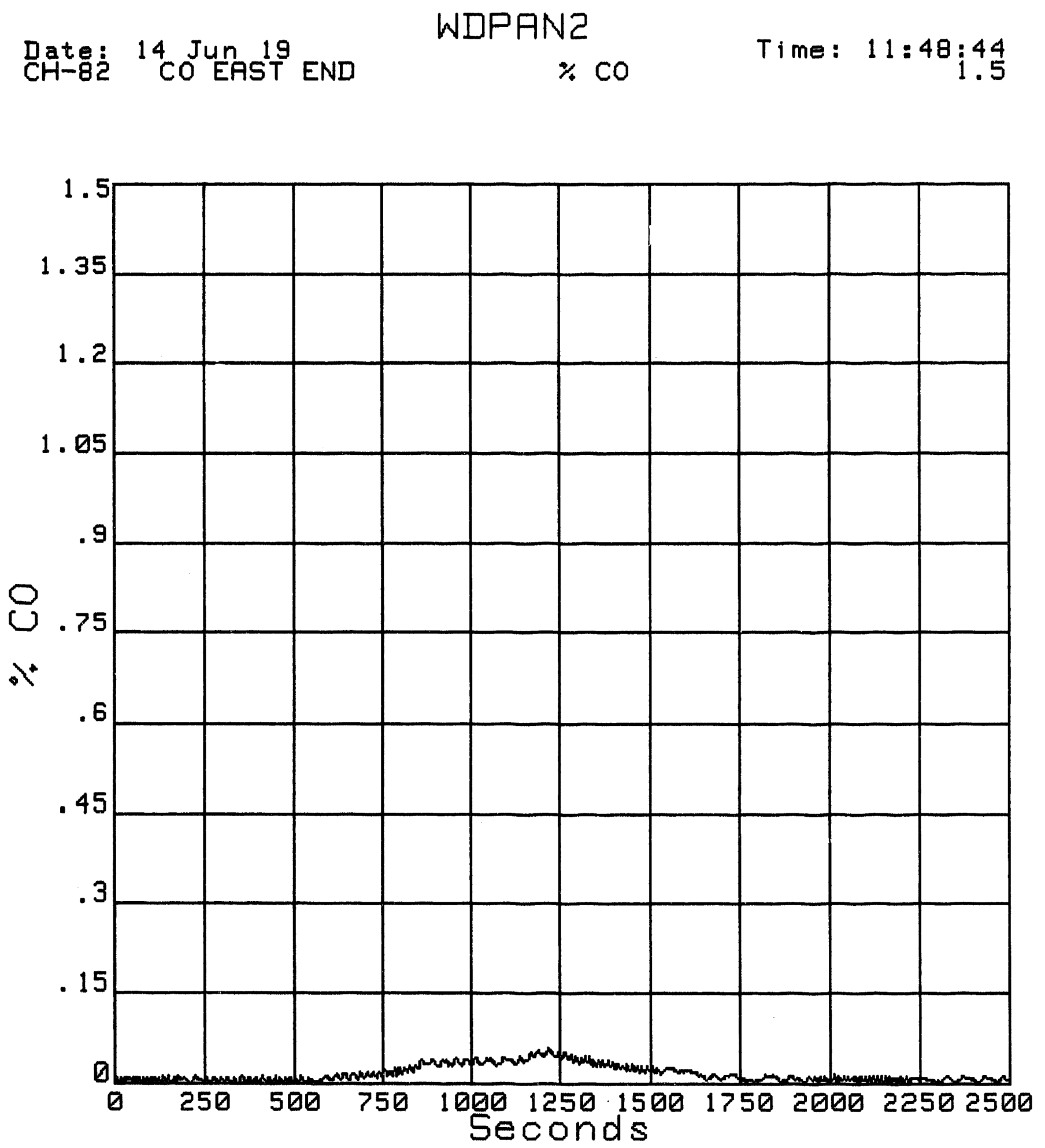

No. of channels $=27$ 
Date: 14 Jun 19 END

WDPAN2

PPM $(=\mathrm{CH} 4)$ Time: $11: 48: 44$

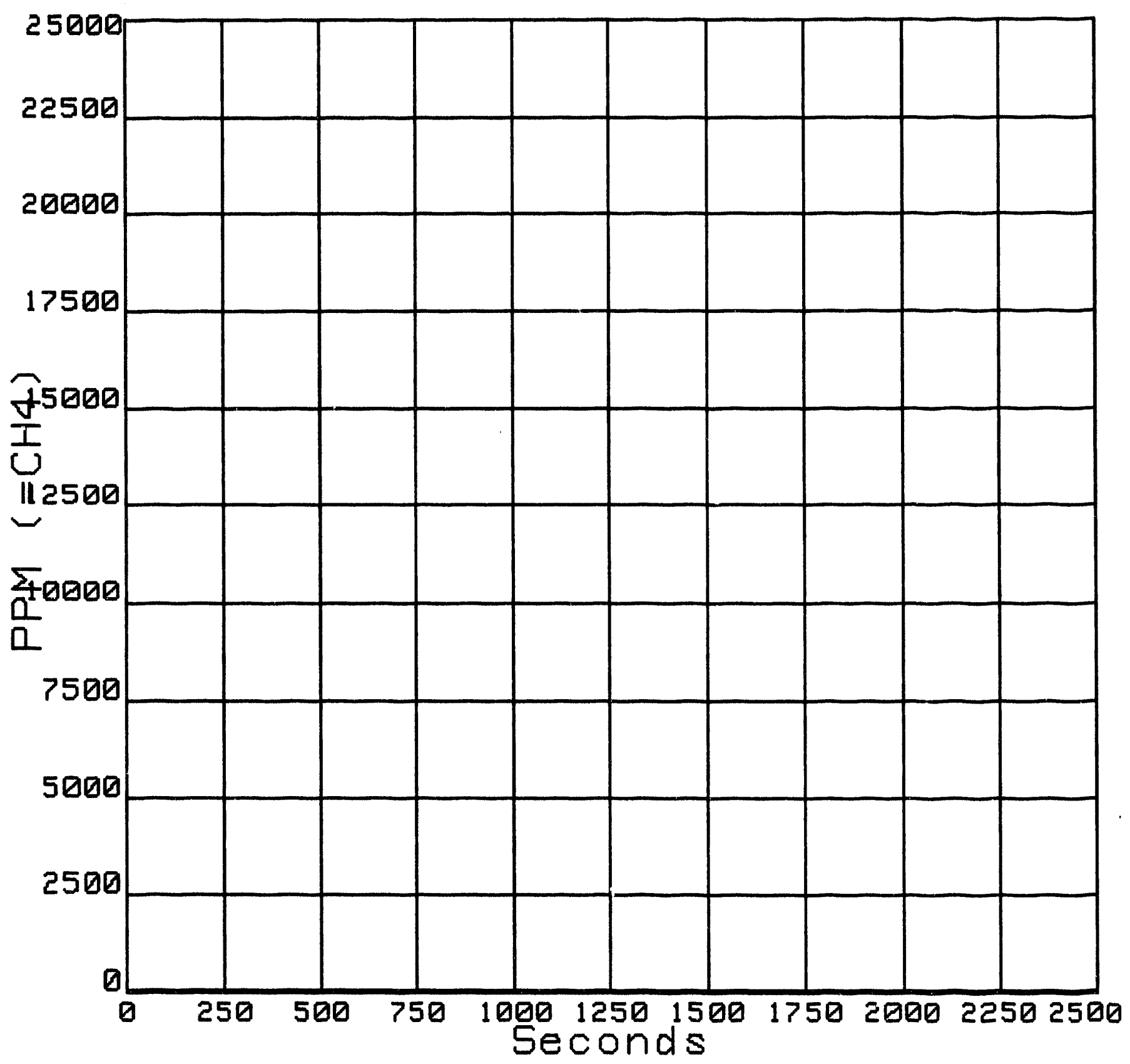

No. of channels $=27$ 

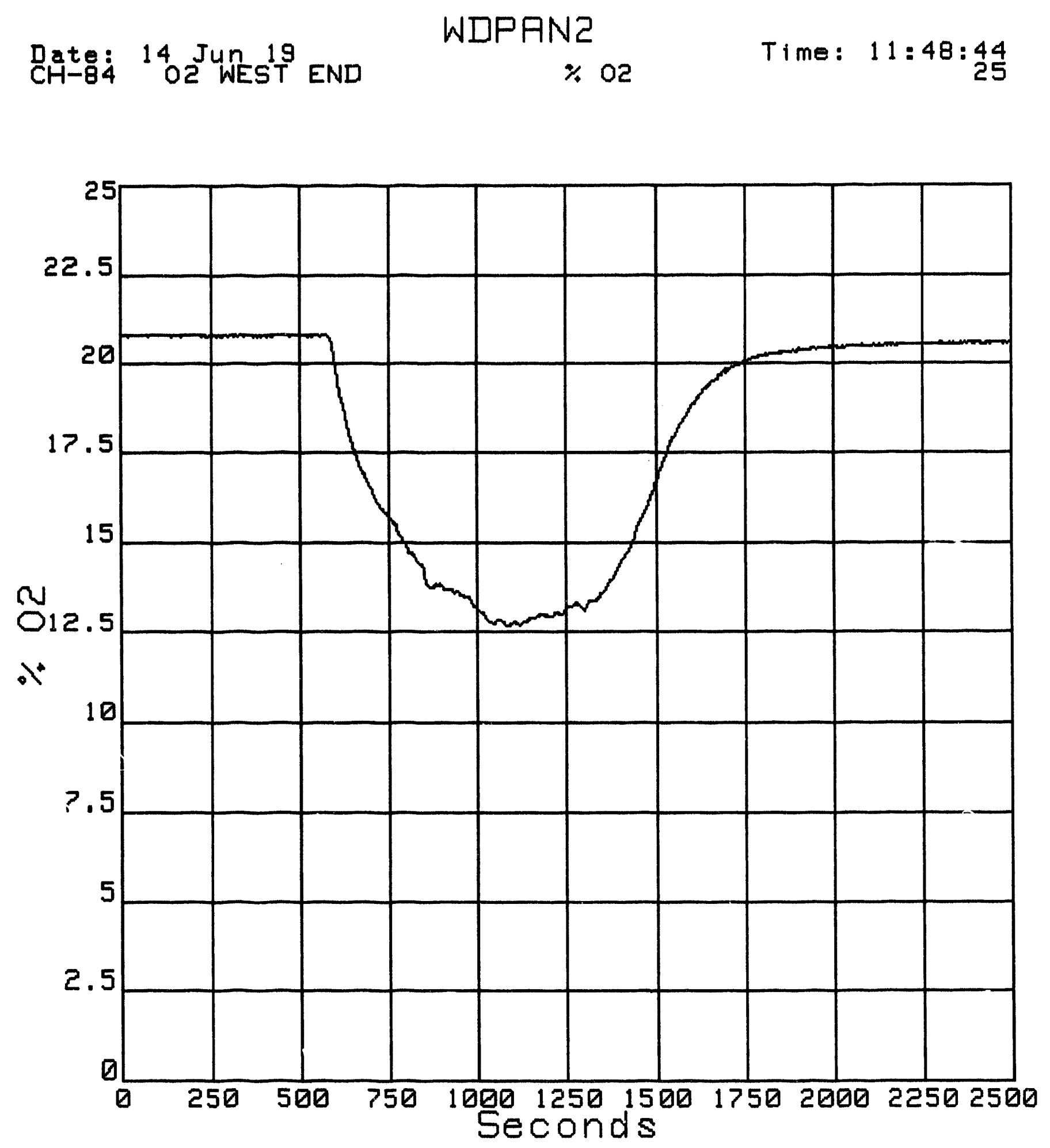

No. of channels $=27$ 
Date: 14 Jun 19 CO2 WEST END

WDPANZ

$\% \cos$

Time: $11: 48: 44$

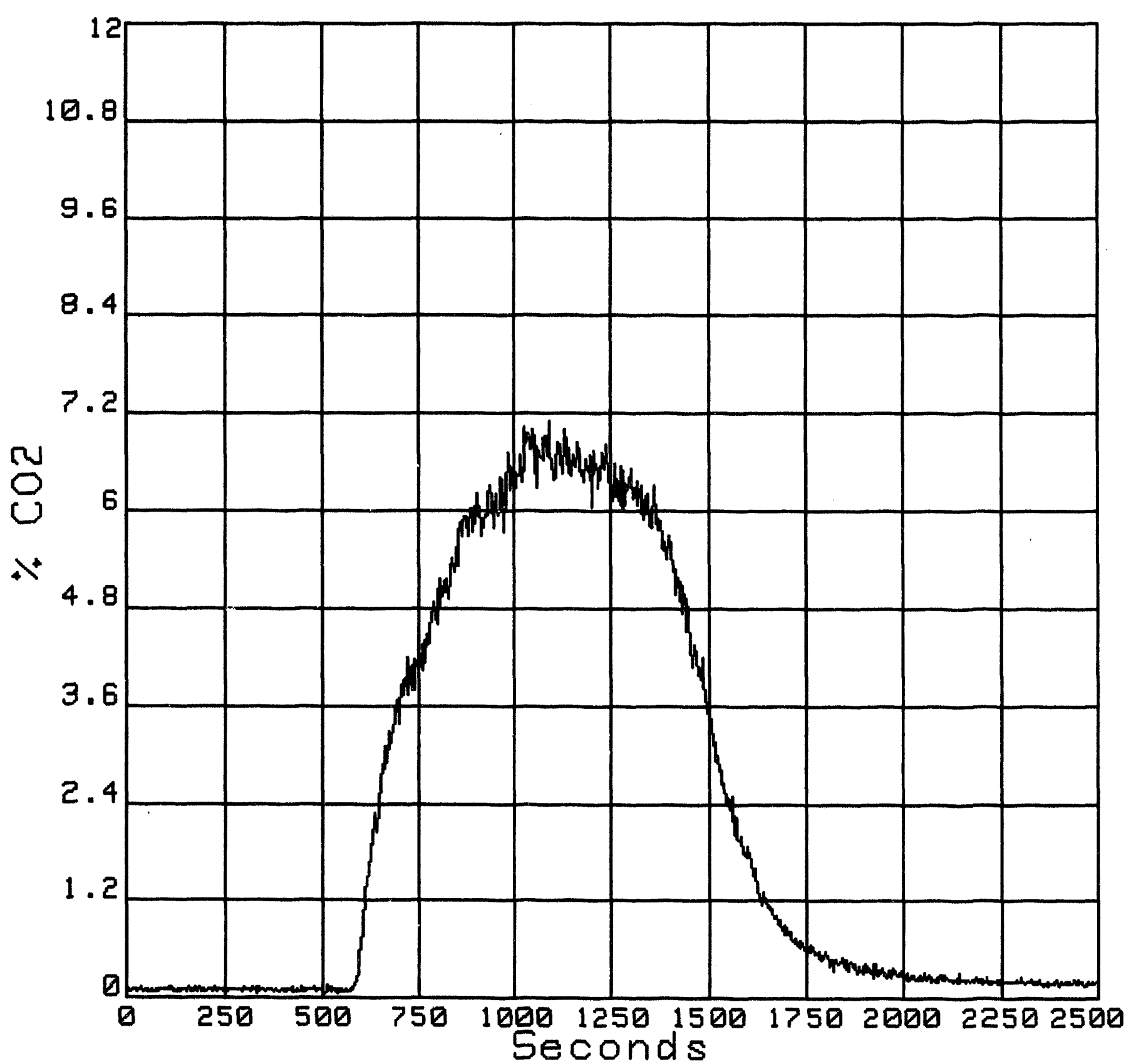

No. of channels $=27$ 